\title{
EVALUATION OF AGRICULTURAL
}

BEST-MANAGEMENT PRACTICES IN THE

CONESTOGA RIVER HEADWATERS,

PENNSYLVANIA: Effects of Pipe-Outlet Terracing

on Quantity and Quality of

Surface Runoff and Ground Water

in a Small Carbonate-Rock Basin

Near Churchtown, Pennsylvania,

1983-89

WATER-QUALITY STUDY OF THE

CONESTOGA RIVER HEADWATERS, PENNSYLVANIA

By Patricia L. Lietman, Linda C. Gustatson-Minnich, and David W. Hail

U.S. GEOLOGICAL SURVEY

Water-Resources Investigations Report 94-4206

Prepared in cooperation with the

PENNSYLVANIA DEPARTMENT OF ENVIRONMENTAL PROTECTION

Lemoyne, Pennsylvania

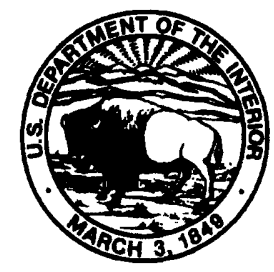




\section{U.S. DEPARTMENT OF THE INTERIOR \\ BRUCE BABBITT, Secretary}

U.S. GEOLOGICAL SURVEY

Gordon P. Eaton, Director

For additional information write to:

District Chief

U.S. Geological Survey, WRD

840 Market Street

Lemoyne, Pennsylvania 17043-1586
Copies of this report may be purchased from:

U.S. Geological Survey Branch of Information Services

Box 25286

Denver Federal Center

Denver, Colorado 80225-0286 


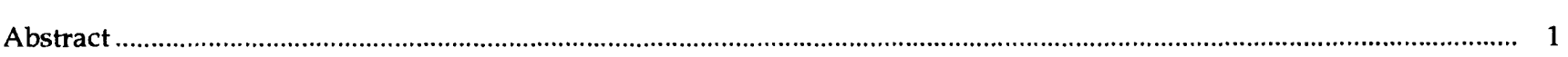

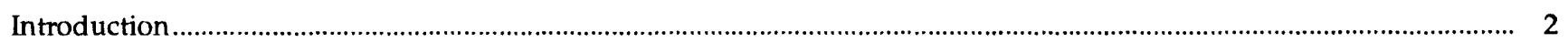

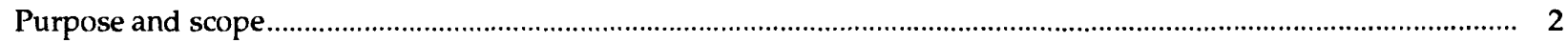

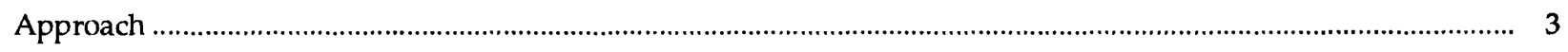

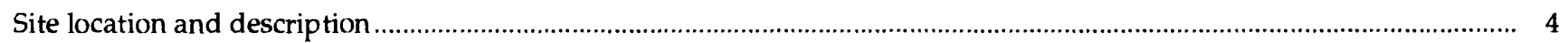

Selected best-management practices ....................................................................................................................

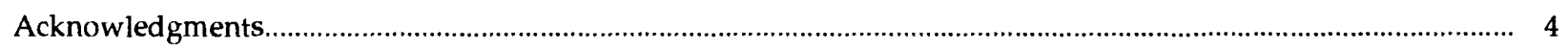

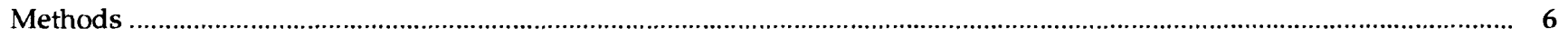

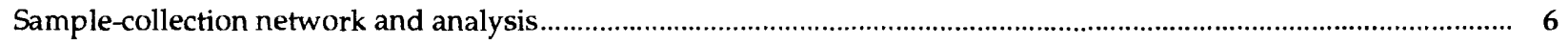

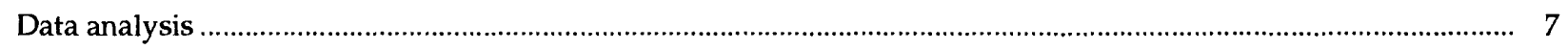

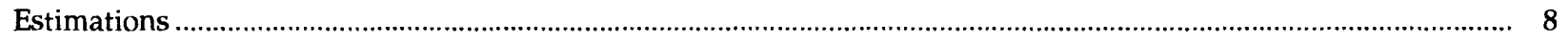

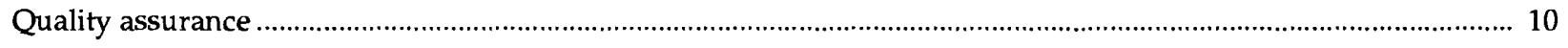

Selected factors that can affect water quantity and quality ............................................................................................... 13

Topography, physiography, and geology ......................................................................................................... 13

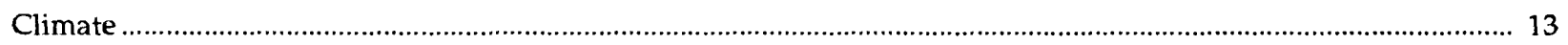

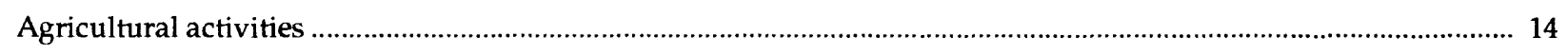

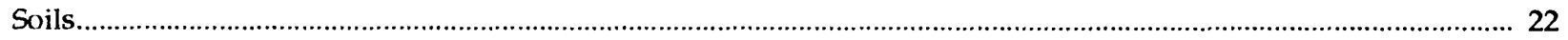

Effects of pipe-outlet terracing on quantity and quality of surface runoff ....................................................................... 25

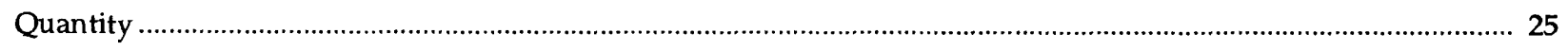

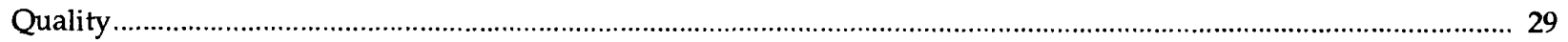

Effects of pipe-outlet terracing on quantity and quality of ground water …................................................................... 46

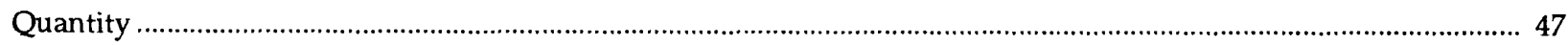

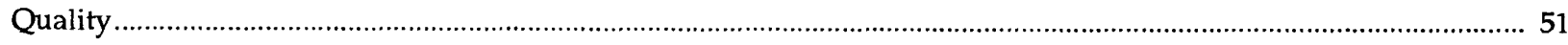

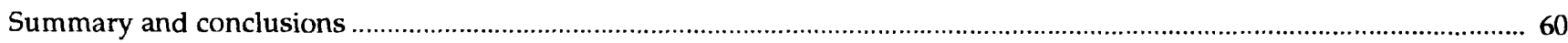

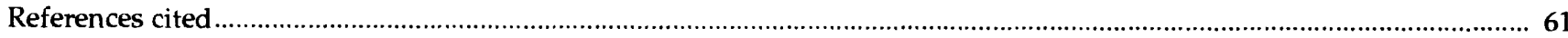




\section{ILLUSTRATIONS}

1.--Location of the Conestoga River Headwaters project area and Field-Site 1

2.--Field-Site 1 topography and surface-runoff, ground-water, and precipitation-sampling locations before and after terraces were constructed

3-4.--Graphs showing:

3.--Total monthly precipitation at Field-Site 1 around normal

4.--Total precipitation at Field-Site 1 during each study period that occurred when the monthly average air temperature was 20 to 80 degrees Fahrenheit.

5.-Cropping patterns at Field-Site 1 for the 1983-89 crop years

6-9.--Graphs showing:

6.--Monthly nitrogen and phosphorus applications to Field-Site 1

7.-Nitrogen-application rates for each field at Field-Site 1 for crop years 1985-89

8.--Concentrations of atrazine in composite soil samples of the top 2 inches at Field-Site 1

9.--Total storm precipitation, maximum 30-minute intensity within each storm, and storm duration for all storms, storms producing runoff, and storms that did not produce runoff during pre-best-management practice Period 1 and post-best-management practice Periods 2, 3, and 4 at Field-Site 1

10.-Hydrographs of runoff at Field-Site 1 for a storm from Periods 1, 2, and 3 with similar amounts of rainfall and similar soil conditions

11-31.--Graphs showing:

11.--Total storm runoff as a function of total precipitation at Field-Site 1 for all runoff events except runoff on frozen ground for pre-best-management practice Period 1 and post-best-management practice Periods 2, 3, and 4

12.--Distribution of precipitation data at Field-Site 1 used to group similar type storms into clusters

13.--Distribution of suspended-sediment and nutrient yields and mean storm concentrations in runoff from Field-Site 1 for pre-best-management practice Period 1 and post-bestmanagement practice Periods 2,3 , and 4

14.--Total suspended-sediment yield in runoff as a function of total storm runoff for all runoff events at Field-Site 1 except runoff on frozen ground for pre-best-management practice Period 1 and post-best-management practice Periods 2, 3, and 4 .

15.--Total nitrate plus nitrite yield in runoff as a function of total storm runoff for all runoff events at Field-Site 1 except runoff on frozen ground for pre-best-management practice Period 1 and post-best-management practice Periods 2,3 , and 4 .

16.--Total ammonia plus organic nitrogen yield in runoff as a function of total storm runoff for all runoff events at Field-Site 1 except runoff on frozen ground for pre-best-management practice Period 1 and post-best-management practice Periods 2, 3, and 4

17.--Total nitrogen yield in runoff as a function of total storm runoff for all runoff events at Field-Site 1 except runoff on frozen ground for pre-best-management practice Period 1 and post-best-management practice Periods 2,3 , and 4

18.--Total phosphorus yield in runoff as a function of total storm runoff for all runoff events at Field-Site 1 except runoff on frozen ground for pre-best-management practice Period 1 and post-best-management practice Periods 2,3 , and 4 ..... 
Figures 11-31.--Graphs showing--Continued

19.--Suspended-sediment concentrations in all samples and in samples analyzed for particle size, and percentage of silt and clay in samples analyzed for particle size during the pre-bestmanagement practice Period 1 and part of the post-best-management practice Periods 2 and 3 at Field-Site 1

20.--Distribution of instantaneous total phosphorus concentrations in all runoff samples and phase of phosphorus in a limited number of samples during the pre-best-management practice Period 1 and part of the post-best-management practice Periods 2 and 3 at Field-Site 1

21.--Mean monthly water-weighted total nitrogen and total nitrate plus nitrite concentrations in runoff from sampled storms and total monthly nitrogen application to Field-Site 1 ..........................45

22.--Mean flow-weighted storm concentration of atrazine at Field-Site 1 for the 1983-87 water years ............ 45

23.--Estimated water-table configuration at Field-Site 1 on November 2, 1982, and transmissivities of the Zooks Corner Formation...

24.-- $A$, Precipitation minus potential evapotranspiration. $B$, Depth to water table from land surface at well LN 514, 11 miles from Field-Site 1, and at wells LN 1643, LN 1645, LN 1646, LN 1650, and LN 1651 at Field-Site 1 for water years 1983-89.

25.--Double-mass comparison of cumulative residuals from 1984 and 1989 water years at wells LN 1659 and LN 1643 at Field-Site 1

26.--Double-mass comparison of cumulative residuals from January 1983 through September 1989 at $\mathrm{LN} 1643$ and wells $A, \mathrm{LN} 1645 ; B, \mathrm{LN} 1646 ; C, \mathrm{LN} 1650$; and $D, \mathrm{LN} 1651$, at Field-Site 1

27.--Concentrations of nitrate (as nitrogen) in recharge and nonrecharge samples at Field-Site 1 collected at wells LN 1643, LN 1645, LN 1646, LN 1650, and LN 1651 and concentrations of all nitrate samples collected at spring LN SP58

28.--Atrazine and cyanazine concentrations in water from wells LN 1645 and LN 1646 at Field-Site 1..........54

29.--Alachlor and metolachlor concentrations in water from wells LN 1645 and LN 1646 at Field-Site 1 ........55

30.--Atrazine concentrations in water samples from well LN 1650 before and after atrazine application on May 23, 1984, at Field-Site 1

31.--Concentrations of nitrate at Field-Site 1 in ground-water samples from wells LN 1643, LN 1645, LN 1646, LN 1650, LN 1651, and spring LN SP58 for pre-best-management Period 1 and post-best-management practice Periods 2, 3, and 4 . 
Table 1.-Data-collection network during the post-best-management practice period (October 1984-July 1989) at Field-Site 1.

2.-Primary characteristics and chemical constituents for which precipitation, surface-runoff, or ground-water samples were analyzed during the post-best-management practice period (October 1984-July 1989)

3.-Sampling schedule for nutrients and herbicides at Field-Site 1 (January 1983-July 1989)

4.--Regression statistics for suspended-sediment and total nutrient yields as a function of total runoff for all sampled storms

5.--Summary statistics for quality-assurance analyses (October 1985-July 1989). 12

6.-Precipitation at Field-Site 1 and the 30-year mean at Morgantown, Pa. 14

7.--Characteristics of storms that occurred at Field-Site 1 16

8.--Crops and acreage at Field-Site 1 for the 1983-89 crop years. 16

9.--Schedule of plowing, planting, and harvesting at Field-Site 1

10.-Nitrogen and phosphorus applied to Field-Site 1 during the post-best-management practice period (October 1984-July 1989)

11.--Nutrient applications to Field-Site 1 by crop 21

12.--Herbicides applied to Field-Site 1, as reported by farmers 22

13.--Summary statistics of nutrient data for soil samples collected at Field-Site 1 from November 1984 through June 1989

14.--Discharge and percentage of precipitation as runoff from Field-Site 1

15.--Regression statistics for the log of total storm runoff at Field-Site 1, in inches, as a function of the log of storm precipitation, in inches, for all storms in each period

16.-General storm characteristics at Field-Site 1, by cluster, and percentage of total precipitation by period and cluster

17.--Summary of Mann-Whitney test results comparing, within clusters, total discharges between pre- and post-best-management practice periods at Field-Site 1

18.--Suspended-sediment and nutrient yields in runoff from Field-Site 1

19.--Regression statistics for suspended-sediment and total nutrient yields as a function of total storm runoff for all runoff events occurring during each period at Field-Site 1

20.--Summary of Mann-Whitney test results comparing, within clusters, mean storm sediment and nutrient concentrations in runoff between pre- and post-best-management practice periods at Field-Site 1

21.--Summary statistics for all storms and storms producing runoff, within clusters, for total discharges and nutrient mean storm concentrations for pre- and post-best-management practice periods at Field-Site 1

22.--Locations and descriptions of ground-water data-collection sites at Field-Site 1

23.--Percentage of precipitation that recharged ground water, ground-water discharge, and dissolved nitrate yields in ground water from Field-Site 1

24.--Median nitrate concentrations in ground water at Field-Site 1 and results of Mann-Whitney testing between pre-and post-best-management practice periods 


\section{CONVERSION FACTORS, VERTICAL DATUM, AND ABBREVIATED WATER-QUALITY UNITS}

Multiply

inch (in.)

inch (in.)

foot (ft)

mile (mi)

acre

square mile $\left(\mathrm{mi}^{2}\right)$

cubic foot per second $\left(\mathrm{ft}^{3} / \mathrm{s}\right)$

gallon per minute per foot $(\mathrm{gal} / \mathrm{min}) / \mathrm{ft}$

cubic foot $\left(\mathrm{ft}^{3}\right)$

gallon (gal)

pound (lb)

ton (short, 2,000 pounds)

pound per ton (lb/ton)

pound per acre (lb/acre)

ton per acre (ton/acre)

pound per gallon (lb/gal)

pound per 100 gallons (lb/100 gal)

square foot per day $\left(\mathrm{ft}^{2} / \mathrm{d}\right)$

degree Fahrenheit $\left({ }^{\circ} \mathrm{F}\right)$
By

To obtain

Length

2.54

25.4

0.3048

1.609

Area

4.047

2.590

Discharge

0.02832

0.2070

Volume

0.02832

3.785

Mass

0.4536

0.9072

0.5000

1.123

2.241

0.1198

11.98

Transmissivity

0.09290

Temperature

${ }^{\circ} \mathrm{C}=5 / 9\left({ }^{\circ} \mathrm{F}-32\right)$

Other Abbreviations

degree Celsius $\left({ }^{\circ} \mathrm{C}\right)$

centimeter millimeter meter kilometer

square kilometer square kilometer

cubic meter per second liter per second per meter

cubic meter

liter

kilogram metric ton kilogram per metric ton kilogram per hectare metric ton per hectare kilogram per liter kilogram per liter

square meter per day

Abbreviated water-quality units used in report:

milligrams per liter ( $\mathrm{mg} / \mathrm{L}$ )

micrograms per liter $(\mu \mathrm{g} / \mathrm{L})$

micrograms per kilogram $(\mu \mathrm{g} / \mathrm{kg})$

micrometers $(\mu \mathrm{m})$

microsiemens per centimeter at 25 degrees Celsius $(\mu \mathrm{S} / \mathrm{cm})$

Sea level: In this report, "sea level" refers to the National Geodetic Vertical Datum of 1929—a geodetic datum derived from a general adjustment of the first-order level nets of the United States and Canada, formerly called Sea Level Datum of 1929. 


\title{
EVALUATION OF AGRICULTURAL BEST-MANAGEMENT PRACTICES IN THE \\ CONESTOGA RIVER HEADWATERS, PENNSYLVANIA:
}

\author{
Effects of Pipe-Outlet Terracing on Quantity and Quality \\ of Surface Runoff and Ground Water in a \\ Small Carbonate-Rock Basin \\ Near Churchtown, Pennsylvania, 1983-89
}

\author{
Patricia L. Lietman, Linda C. Gustafson-Minnich, and David W. Hall
}

\begin{abstract}
The effects of terracing on the quantity and quality of surface runoff and ground water were investigated by the U.S. Geological Survey, in cooperation with the Pennsylvania Department of Environmental Protection, during 1983-89 at a 23.1-acre agricultural site in Lancaster County, Pa., as part of the 1982 Rural Clean Water Program. The site, underlain by carbonate rock, was primarily corn and alfalfa fields; the median slope was 6 percent. Normal precipitation was about 42 inches per year. Average annual runoff was 11 percent, and ground-water recharge was 37 percent of precipitation. Runoff quantity, suspended-sediment and nutrient data, ground-water level and nutrient data, and precipitation-quantity data were collected for 21 months prior to, and 58 months after, construction of pipe-outlet terraces. Data were analyzed by use of graphical, regression, covariate, cluster, Mann-Whitney Rank Sum test, and double-mass curve techniques.
\end{abstract}

Terracing changed runoff characteristics. Storm characteristics were similar throughout the study period. However, after terracing, storms producing less than 0.4 inch of precipitation rarely produced runoff. Total storm discharge as a function of precipitation did not change significantly throughout the range of runoff-producing storms after terracing. Multiple discharge peaks on hydrographs before terracing did not occur after terracing when hydrographs reflected the stepwise draining of each terrace through the pipe outlet.

After an initial 2-year period of terrace stabilization, suspended-sediment yield in runoff decreased significantly as a function of runoff. This result was expected because terracing decreased runoff energy and because terrace ponding allowed time for sediment redeposition.

Nitrate plus nitrite yields increased proportionally throughout the range of runoff during the post-terracing period relative to the pre-terracing period. After terracing, a combination of increased soil contact time and increased nitrification caused by wetter soils is believed to have increased nitrate concentrations in runoff.

No significant change was found in yields of total nitrogen, ammonia plus organic nitrogen, or total phosphorus relative to runoff before and after terracing. Limited data suggest that fine-sediment particles (less than 0.62 micrometers in diameter), which continued to be discharged from the site, transported most of the phosphorus.

Terracing did not significantly change the quantity of recharge to the carbonate aquifer. The mean annual water-table altitude did not change after terracing. Nitrate concentrations of ground water increased significantly at four of the site wells after terracing, probably because of increased contact time of the recharge with nutrient-rich soils in ponded terrace water. Qualitative evidence indicates that large decreases in nutrient requirements and nitrogen applications because of a crop change from corn to alfalfa upgradient of two site wells resulted in either no detectable change or a significant decrease in nitrate concentrations of ground water after terracing. 


\section{INTRODUCTION}

The U.S. Geological Survey (USGS), in cooperation with the Pennsylvania Department of Environmental Protection (PaDEP) $)^{1}$, conducted a study to determine the effects of agricultural best-management practices (BMP's) on surface-water and ground-water quality. This study is one of five comprehensive monitoring and evaluation projects in the U.S. Department of Agriculture's (USDA) Rural Clean Waters Program (RCWP).

The RCWP, enacted by the U.S. Congress in 1979, designated the Conestoga River Headwaters Basin in Pennsylvania as 1 of 20 project areas approved for remedial action to improve stream- and ground-water quality. This area was chosen because it had previously been designated as the top priority watershed in Pennsylvania's Agricultural 208 Plan. This designation had been made because the project area contains 132 mi of streams that have considerable existing or potential use for water supply, livestock watering, fish, wildlife, and recreation as well as significant ground-water use for public water supplies. Also, previous studies (U.S. Department of Agriculture, 1982; Lancaster County Conservation District, 1982; Pennsylvania Department of Environmental Resources, 1983) have demonstrated increasing degradation of surface- and ground-water quality caused by large nonpoint discharges of suspended sediment and nutrients. The major water-quality problems include nutrients from manure, pesticides from applications to cropland, and sediment from erosion of intensively cropped land.

The objective of the RCWP was to improve surface-water and ground-water quality by voluntary implementation of BMP's, such as construction of terraces, manure storage facilities, and grassy waterways and management of nutrients and pesticides. Funds were allocated to the selected project areas to implement these practices with cost-sharing as an incentive and to monitor the effects of implementation on water quality.

Water-quality monitoring in the 188- $\mathrm{mi}^{2}$ Conestoga River Headwaters Basin was conducted over a 10-year period (1982-91) at three scales: regional, small watershed, and field. These areas were being monitored before and after implementation of BMP's to determine the effects of BMP's on surface-water and ground-water quality. A detailed description of the overall study can be found in "Evaluation of Agricultural Best-Management Practices in the Conestoga River Headwaters, Pennsylvania: Methods of Data Collection and Analysis, and Description of Study Areas" (Chichester, 1988).

Field-Site 1, discussed in this report, was located in the Conestoga River Headwaters Basin, between Churchtown and Goodville, Lancaster County, Pa. (fig. 1). The site, underlain by carbonate rock, was conventionally tilled cropland, planted primarily in corn and alfalfa. A detailed characterization of Field-Site 1 can be found in "Evaluation of Agricultural Best-Management Practices in the Conestoga River Headwaters, Pennsylvania: Characterization of Surface-Runoff and Ground-Water Quantity and Quality in a Small Carbonate Basin Near Churchtown, Pennsylvania, Prior to Terracing and Implementation of Nutrient Management" (Lietman and others, 1996).

\section{Purpose and Scope}

This report documents the effects of terracing and nutrient management on surface-water and ground-water quantity and quality of a 23.1-acre field site, Field-Site 1, in the Conestoga River Headwaters project area. Climatological, agricultural-activity, and soil data as well as surface- and ground-water quantity and quality data collected after implementation of BMP's (October 1984 through September 1989) are compared to the same type of data collected at the site before the implementation of BMP's. The pre-BMP period, from January 1983 through September 1984, is referred to as Period 1. Data from the post-BMP phase of the study is grouped into three time periods-October 1984 through September 1986 is Period 2, October 1986 through September 1988 is Period 3, and October 1988 through July 1989 is Period 4. As documented in the following sections, Period 3

\footnotetext{
${ }^{1}$ Prior to 1995, the Pennsylvania Department of Environmental Protection was the Pennsylvania Department of Environmental Resources.
} 


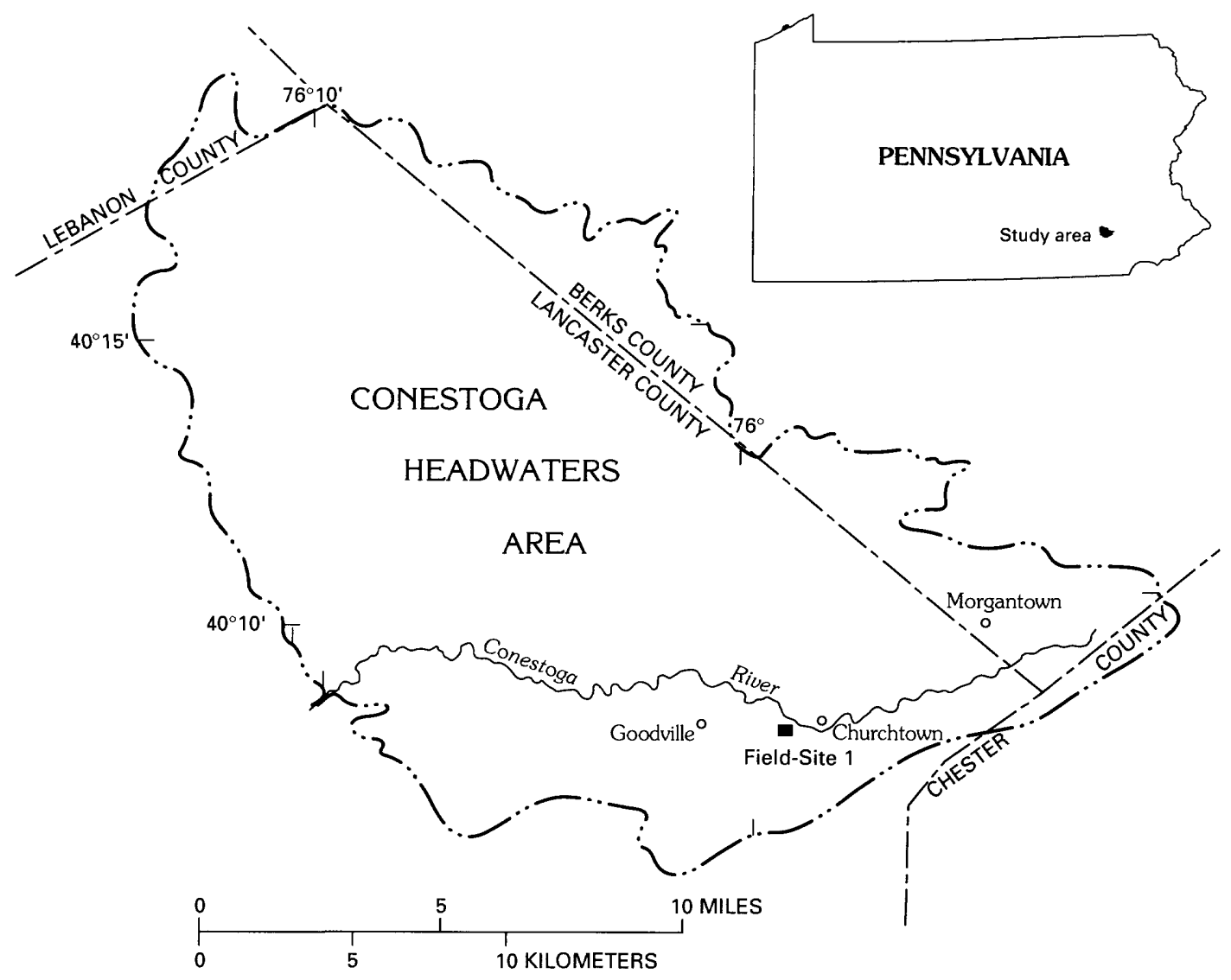

Figure 1.--Location of the Conestoga River Headwaters project area and Field-Site 1.

in the post-BMP phase is the most comparable period to Period 1, the pre-BMP period, in terms of annual precipitation and nutrient applications to the field. (The 1988 water year ${ }^{2}$ is comparable to the 1983 water year, and the 1987 water year is comparable to the 1984 water year.) In addition, by October 1986, the terraces were well established (settled), and cropping patterns were stable. Therefore, data from Period 3 and Period 1 are compared more frequently throughout this report for discussion of changes because of BMP implementation. The 1989 water-year data were not used as frequently for comparative analysis as the other periods because (1) the cropping pattern for the 1989 water year differed radically from all previous years studied, from 65-80 percent corn and 35-20 percent alfalfa in Periods 1 to 3 to 10 percent corn and 90 percent alfalfa in Period 4; (2) regularly scheduled data collection ended in July 1989, so the water year's data is incomplete; and (3) the duration of the 1989 water-year data record is less than half that of the other periods. Because the inclusion of data from Period 4 would be misleading in some of the comparative analyses, it is excluded from some of the analyses in this report. Data from the entire post-BMP period is also sometimes compared to the pre-BMP data.

\section{Approach}

Climatological conditions are compared to help analyze and normalize the water-quality data for the different periods. Changes in agricultural activities, particularly nutrient-management strategies from the pre-BMP to the post-BMP periods, are discussed. Concentrations of nutrients in the soil are compared to

${ }^{2} \mathrm{~A}$ water year is the 12 -month period beginning on October 1 and ending on September 30 and is designated by the calendar year in which it ends. 
determine changes that may affect the water quality. Quantitative and statistical analyses of the water-quality data are performed to evaluate the differences among the different study periods and to determine whether changes in water quality are attributable to the implementation of the BMP's.

All nitrogen or phosphorus species are expressed as their elemental form. For example, whether discussing ammonia or nitrate concentrations or loads, all values are expressed as nitrogen. The term ammonia refers to the ammonia ion plus free ammonium. The growing season, for the purposes of this report, is defined as the period May through October, and the nongrowing season as the period November through April.

\section{SITE LOCATION AND DESCRIPTION}

The 23.1-acre site, which is underlain by carbonate rock, is located in the Conestoga River Headwaters, between Churchtown and Goodville, Lancaster County, Pa. (fig. 1). The site, part of two dairy farms, was unirrigated, conventionally tilled cropland and was planted primarily in corn and alfalfa during the study period. The silt loam soils are up to $60 \mathrm{in}$. deep and are moderately to well drained. The terraced site has an overall slope of about 6 percent.

\section{Selected Best-Management Practices}

The BMP's implemented at Field-Site 1 were terracing and nutrient management. Six pipe-outlet terraces, designed to accommodate a 5-in., 24-hour storm, were constructed between October 19, 1984, and November 16, 1984. (The four lower terraces were rebuilt in May 1985 shortly after runoff, from a thunderstorm on May 21, 1985, overflowed the terraces and created severe gully formation.) The terrace construction changed the topography of the site and increased the surface drainage area from 22.1 to 23.1 acres (fig. 2). The terraces were graded so that each terrace sloped gently downgradient toward the center of the field. The terraces trapped runoff in pools that drain slowly through a pipe outlet. During the post-BMP period, surface runoff was water that left the upper 90 percent of the site through the pipe-outlet system plus surface runoff from the unterraced lower 10 percent of the site. Under extreme storm conditions, runoff breached the terrace structures. In contrast, surface runoff during the pre-BMP period was unimpeded by structural devices and created small feeder gullies throughout the site and massive receiving gullies in the lower one-third of the site.

The nutrient-management plan for the site was developed in November 1984 through the use of historical application data and soil- and manure-nutrient analysis. The plan recommended manure and fertilizer applications related to crop-nutrient needs, rather than to manure-disposal needs. The timing of nutrient applications also was recommended to be changed from daily spread to the time the crops could most readily use these nutrients. A facility for the storage of manure for 6 months was constructed. However, as will be shown, nutrientmanagement planning did not result in a substantial change in the quantity of applied nutrients.

\section{Acknowledgments}

The authors acknowledge the dedicated efforts of many people who have made this study possible. John Hauenstein, Charles Takita, and Gary Lesher of the Susquehanna River Basin Commission provided field assistance and surveyed and mapped the site. Many employees of the Natural Resources Conservation Service and the Consolidated Farm Service Agency at the State and local levels provided assistance in the planning and implementation of management practices on the site and provided technical assistance to the project. Donald Robinson and Robert Anderson of the Eastern Lancaster County School District assisted in the selection of the site and provided field and technical assistance. Dr. Dale Baker from The Pennsylvania State University provided assistance and equipment for collecting soil samples. The authors also wish to acknowledge the farm operators of the site for allowing us to conduct this study on their farms and for providing land-use information. 


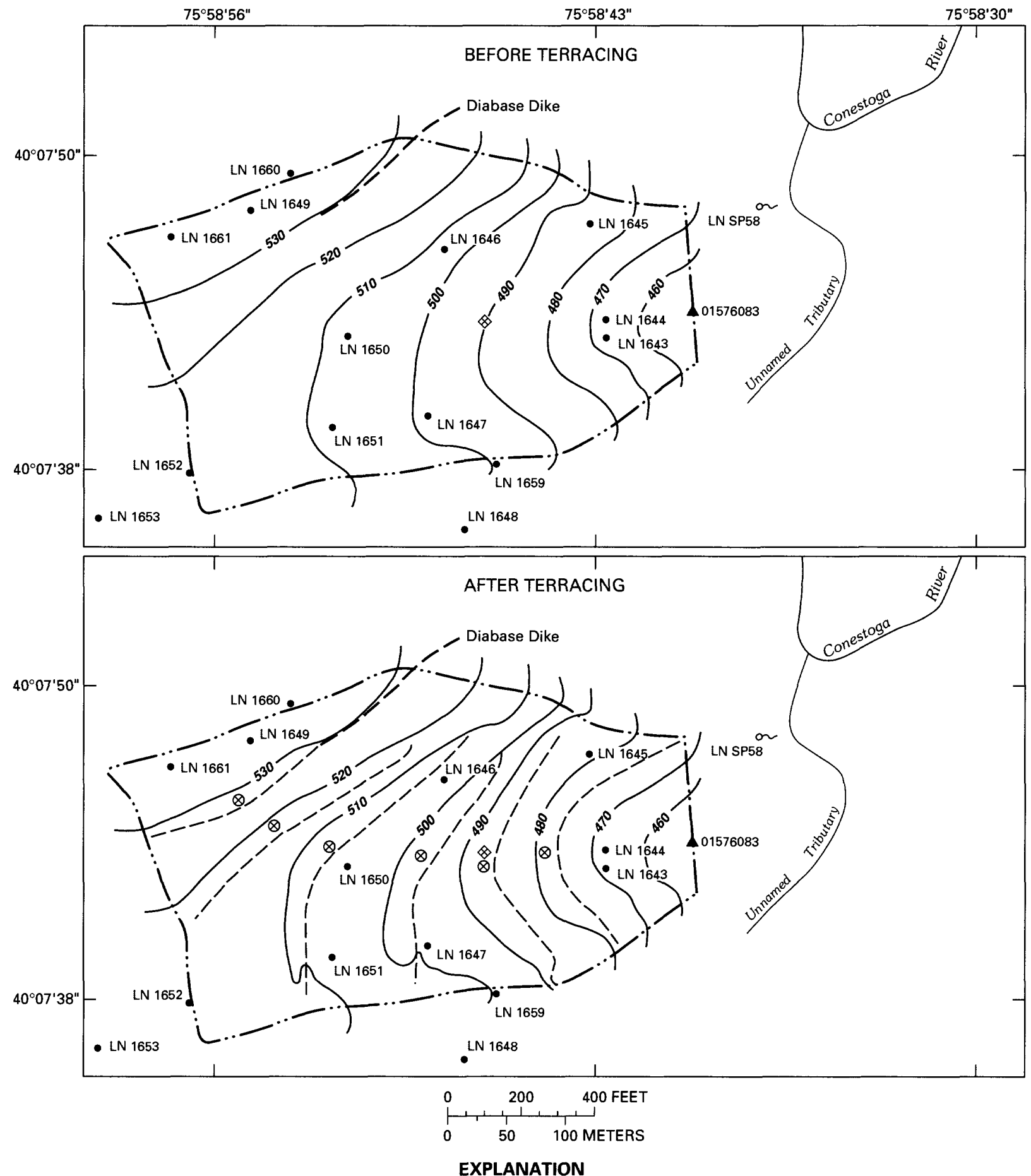
- -.- DRAINAGE-BASIN DIVIDE
$\triangle 01576083$ SURFACE-RUNOFF GAGING STATION
- 500 - TOPOGRAPHIC CONTOUR LINE. INTERVAL IO FEET. DATUM IS SEA LEVEL
- - - TERRACE CREST
$\otimes \quad$ PRECIPITATION STATION
- LN 1648 WELL WITH IDENTIFICATION NUMBER LN SP58 SPRING WITH IDENTIFICATION NUMBER
$\otimes$ INTAKE PIPE FOR TERRACE DRAINAGE SYSTEM

Figure 2.--Field-Site 1 topography and surface-runoff, ground-water, and precipitation-sampling locations before and after terraces were constructed (construction occurred between October 19, 1984, and November 16, 1984). 


\section{METHODS}

\section{Sample-Collection Network and Analysis}

Detailed information on methods of data collection and sample and data analysis is presented in Chichester (1988), Lietman and others (1989), and Lietman and others (1996). Modification to the procedures described in these reports and used for data collection and sample and data analysis at Field-Site 1 during the post-BMP period are described in this section. The data-collection network for the post-BMP period is summarized in table 1, and data-collection sites are shown in figure 2. The list of characteristics and chemical constituents for which water samples were analyzed and associated laboratory minimum reporting levels ${ }^{3}$ and U.S. Environmental Protection Agency (USEPA) Primary Drinking-Water Regulations are shown in table 2 for the post-BMP period. The sampling schedule for nutrients and herbicides varied throughout the 79-month study period. The changes in the schedule are shown in table 3.

For the post-BMP period, all water-quality samples were analyzed by the PaDEP, Bureau of Laboratories, except for triazine herbicides samples collected from September 1, 1988, through December 31, 1988, which were analyzed by the USGS National Water Quality Laboratory in Arvada, Colo. All suspended-sediment and particle-size samples were analyzed by the USGS Sediment Laboratory in Lemoyne, Pa. All soil samples were analyzed by The Pennsylvania State University, Soils and Environmental Chemistry Laboratory, University Park, Pa., and all manure samples were analyzed by A\&L Eastern Agricultural Laboratories, Inc., Richmond, Va. ${ }^{4}$

Water-quality data collected during this study were published in U.S. Geological Survey Water-Resources Data Reports PA-83-2 to PA-89-2 (Buchanan and others, 1984; Loper and others, 1985-90) and are stored in the USGS WATSTORE and USEPA STORET data bases. The data were catalogued by the USGS local identification numbers used in this report. All data are on file in the USGS office in Lemoyne, Pa.

The mean monthly temperatures are used to calculate potential evapotranspiration for Field-Site 1 for the 1985-89 water years. In February 1986, the National Oceanic and Atmospheric Administration (NOAA) stopped publishing monthly temperatures for the station in Morgantown, Pa. Another nearby NOAA station, Hopewell Village, Pa., was selected to provide representative temperature data for the field site, because comparison of monthly temperature data from October 1984 to January 1986 showed little differences between temperatures at the two stations (National Oceanic and Atmospheric Administration, 1984, 1985, 1986). The potential evapotranspiration was calculated by use of techniques described by Thornthwaite (1948).

Two- and 4-ft-deep soil cores were collected from two fields planted in corn except during the summer 1989 sampling when alfalfa was seeded, and from the part of a field planted in alfalfa. Soil cores were collected during the spring ( $4 \mathrm{ft}$ deep), summer ( $2 \mathrm{ft}$ deep), and fall ( $4 \mathrm{ft}$ deep) from the fall 1984 through the summer 1989, except for the spring and summer 1985 . The soil cores were split into 0-8-in., 8-24-in., and 24-48-in.-depth sections and analyzed for soluble nitrate and phosphorus.

In addition, composite field soil samples were collected of the top 2 in. of soil from 13 locations spread over the field. These samples were analyzed for triazine herbicides and sometimes for particle-size distribution. Soil samples were collected during the spring, summer, and fall, from the fall of 1984 through the fall of 1987 except for the spring of 1987.

\footnotetext{
${ }^{3}$ The smallest measured concentration of a constituent that may be reliably reported by the use of a given analytical method.

${ }^{4}$ The use of trade, product, or firm names in this report is for identification purposes only and does not constitute endorsement by the U.S. Geological Survey.
} 
Table 1.--Data-collection network during the post-best-management practice period (October 1984-July 1989) at Field-Site 1

\begin{tabular}{|c|c|c|c|}
\hline Medium & $\begin{array}{l}\text { Number } \\
\text { of locations }\end{array}$ & $\begin{array}{l}\text { Data-collection } \\
\text { frequency }\end{array}$ & $\begin{array}{l}\text { Analyses performed } \\
\text { or data collected }\end{array}$ \\
\hline Precipitation & 1 & $\begin{array}{l}\text { 5-minute intervals during storms; } \\
7 \text { times during study period }\end{array}$ & $\begin{array}{l}\text { Volume } \\
\text { Nutrient concentration }\end{array}$ \\
\hline $\begin{array}{l}\text { Agricultural } \\
\text { activities }\end{array}$ & Entire site & Biweekly & $\begin{array}{l}\text { Nutrient and herbicide-application timing and } \\
\text { rates; crop planting, plowing, and harvesting } \\
\text { locations and dates }\end{array}$ \\
\hline Manure & Varied & At selected major applications & Nutrient concentration \\
\hline Soil & Varied & Spring, summer, fall & Nutrient and herbicide concentration \\
\hline Runoff & 1 & $\begin{array}{l}\text { All runoff events } \\
\text { Most runoff events } \\
\text { Selected runoff events; } \\
\quad 1985-87 \text { water years }\end{array}$ & $\begin{array}{l}\text { Volume } \\
\text { Suspended-sediment and nutrient concentration } \\
\text { Herbicide concentration }\end{array}$ \\
\hline Ground water & $\begin{array}{l}6 \text { wells } \\
8 \text { wells } \\
5 \text { wells; } 1 \text { spring } \\
2 \text { wells }\end{array}$ & $\begin{array}{l}\text { Continuous } \\
\text { Intermittent } \\
\text { Monthly plus selected recharge events } \\
\text { Selected months, selected events }\end{array}$ & $\begin{array}{l}\text { Water level } \\
\text { Water level } \\
\text { Specific conductance, nutrient concentration } \\
\text { Herbicide concentration }\end{array}$ \\
\hline
\end{tabular}

\section{Data Analysis}

Statistical procedures were used for summarizing data, making statistically supported inferences about the data, and defining explanatory relations between various data. The data are summarized by descriptive statistics such as means, medians, ranges, and percentiles. Statistical inferences about data normality, differences between data set means or medians, linear-regression analyses, and analysis of covariance were based on the results of hypothesis testing. The null hypothesis was that no change occurred. All hypothesis tests were performed at the 95-percent confidence level except where noted. Data normality was tested by use of the Shapiro-Wilk method. Differences between central values of data sets were tested with nonparametric procedures: the Wilcoxon Signed-Rank for match-pair data, and the Mann-Whitney Rank Sum test for independent observations. These procedures do not require an assumption of normality or transformation of the data. A more complete discussion of basic descriptive, parametric, and nonparametric procedures used can be found in Iman and Conover (1983), Conover (1980), Searcy and Hardison (1960), and Helsel and Hirsch (1992). All statistical procedures were run on software from the Statistical Analysis System (SAS) Institute, Inc. (1979, 1982a, 1982b), P-STAT, Inc. (1986), or SYSTAT, Inc. (Wilkinson, 1988).

To account for differences between study periods, relations between hydrologic, climatic, and agriculturalactivities data for runoff were explored using linear regression and analysis of covariance. The Mallows' $\mathrm{C}_{\mathrm{p}}$ statistic and the adjusted coefficient of determination $\left(R^{2}\right.$ values) (adjusted for degrees of freedom and number of independent variables) were used to choose the best regression models. The F-test was used to test for overall regression significance, and the t-test was used for significance of regression coefficients. In addition, residual plots and diagnostics for outliers, influence, and leverage were evaluated for each regression. Cluster analysis was used to separate runoff data for comparison of similar type storms occurring during different periods.

For ground water, double-mass curves of data residuals were used to evaluate changes in quantities of recharge that may have resulted from terracing of the site. All changes in quantities of recharge that occurred after terracing of the site were evaluated for statistical significance by the use of analysis of covariance. 
Table 2.--Primary characteristics and chemical constituents for which precipitation, surface-runoff, or groundwater samples were analyzed during the post-best-management practice period (October 1984-July 1989)

$\left[{ }^{\circ} \mathrm{C}\right.$, degrees Celsius; $\mu \mathrm{S} / \mathrm{cm}$, microsiemens per centimeter at 25 degrees Celsius; $\mathrm{mg} / \mathrm{L}$, milligrams per liter; $\mu \mathrm{g} / \mathrm{L}$, micrograms per liter; $\mathbf{m L}$, milliliters]

\begin{tabular}{|c|c|c|}
\hline $\begin{array}{l}\text { Characteristic } \\
\text { or constituent }\end{array}$ & $\begin{array}{l}\text { Laboratory minimum } \\
\text { reporting levels }{ }^{1}\end{array}$ & $\begin{array}{l}\text { U.S. Environmental Protection } \\
\text { Agency Primary Drinking- } \\
\text { Water Regulation }\end{array}$ \\
\hline Temperature (field) & Measured to nearest $0.5^{\circ} \mathrm{C}$ & \\
\hline Specific conductance (field) & 1 to $10 \mu \mathrm{S} / \mathrm{cm}$ dependent on value & \\
\hline Suspended sediment & $1 \mathrm{mg} / \mathrm{L}$ & \\
\hline \multicolumn{3}{|l|}{ Total and dissolved nutrients: } \\
\hline Ammonia $^{2}$ plus organic nitrogen & $0.2 \mathrm{mg} / \mathrm{L}$ & \\
\hline Ammonia $^{2}$ & $.02 \mathrm{mg} / \mathrm{L}$ & \\
\hline Organic nitrogen (calculated) & $.2 \mathrm{mg} / \mathrm{L}$ & \\
\hline Nitrate plus nitrite & $.04 \mathrm{mg} / \mathrm{L}$ & \\
\hline Nitrite & $.01 \mathrm{mg} / \mathrm{L}$ & \\
\hline Nitrate (calculated) & $.04 \mathrm{mg} / \mathrm{L}$ & ${ }^{3} 10 \mathrm{mg} / \mathrm{L}$ \\
\hline Phosphorus & $.02 \mathrm{mg} / \mathrm{L}$ & \\
\hline \multicolumn{3}{|l|}{ Total herbicides ${ }^{4}$ : } \\
\hline \multirow[t]{2}{*}{ Atrazine } & $.1 \mathrm{mg} / \mathrm{L}$, October 1984-March 1987 & $33 \mu \mathrm{g} / \mathrm{L}$ \\
\hline & .3 mg/L, April 1987-September 1989 & ${ }^{5} 3 \mu \mathrm{g} / \mathrm{L}$ \\
\hline \multirow[t]{2}{*}{ Cyanazine } & $.2 \mathrm{mg} / \mathrm{L}$, October 1984-March 1987 & ${ }^{5} 1 \mu \mathrm{g} / \mathrm{L}$ \\
\hline & $.3 \mathrm{mg} / \mathrm{L}$, April 1987-September 1989 & \\
\hline \multirow[t]{2}{*}{ Propazine } & $.2 \mathrm{mg} / \mathrm{L}$, October 1984-March 1987 & ${ }^{5} 10 \mu \mathrm{g} / \mathrm{L}$ \\
\hline & $.3 \mathrm{mg} / \mathrm{L}$, April 1987-September 1989 & \\
\hline Alachlor & $.05 \mathrm{mg} / \mathrm{L}$ & ${ }^{3} 2 \mu \mathrm{g} / \mathrm{L}$ \\
\hline Metolachlor & $.1 \mathrm{mg} / \mathrm{L}$ & ${ }^{5} 100 \mu \mathrm{g} / \mathrm{L}$ \\
\hline \multicolumn{3}{|c|}{$\begin{array}{l}1 \text { The smallest measured concentration of a constituent that may be reliably reported by the use of a given analytical method } \\
2 \text { Ammonia in this report represents ammonia plus ammonium. } \\
{ }^{3} \text { Maximum Contaminant Level (U.S. Environmental Protection Agency, 1992). } \\
{ }^{4} \text { The detection limit of herbicides is as described above if the recommended } 1,900 \mathrm{~mL} \text { of sample is used in analysis. For } \\
\text { es with substantial suspended-sediment concentrations, such as was the case with many runoff samples, a smaller volume of } \\
\text { e was used for analysis because of interferences caused by the suspended material. For samples with less than } 1,900 \mathrm{~mL} \text { of } \\
\text { e, the detection limit varied proportionately with the amount of sample used for analysis. } \\
{ }^{5} \text { Lifetime health advisory level (U.S. Environmental Protection Agency, 1992). }\end{array}$} \\
\hline
\end{tabular}

\section{Estimations}

Total daily precipitation was estimated by use of records from nearby USGS rain gages and NOAA stations when there was a missing record at the field site caused by equipment malfunction at Morgantown and Hopewell Village, Pa. In addition, for storms that occurred during November through March, missing storm-duration and maximum 30-minute storm-intensity data were estimated when possible by use of records from a USGS rain gage located a few miles to the east of the field site. Storm duration and intensity were estimated only during these months, when storms tend to be uniform between the two rain gages. A regression analysis of duration and maximum 30-minute intensity data between the two gages showed good correlation between the data from the two gages; adjusted $R^{2}$ values are 0.91 and 0.66 , respectively, and p-values were $<0.001$. 


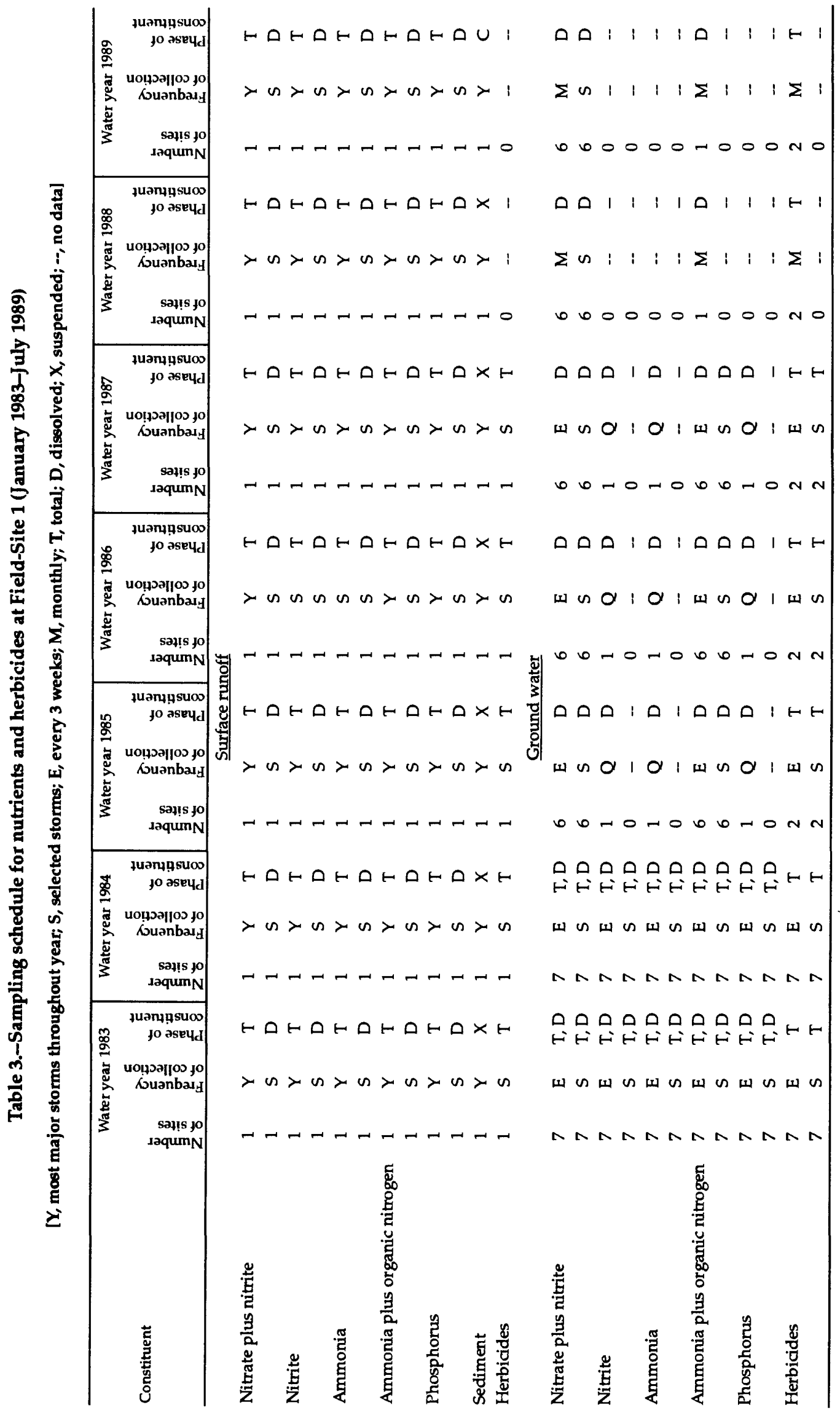


Suspended-sediment and nutrient loads for unsampled runoff events were estimated by use of the individual regression equations derived from log-transformed calculated loads as a function of log-transformed total runoff from sampled runoff events (table 4). Regression analyses were performed separately for data from the growing season (May through October) and the nongrowing season (November through April) in order to make calculations on the basis of runoff occurring during similar field conditions. Scatter plots were used to verify all the regression analyses. For the 79 months of study, 19 percent of the suspended-sediment load, 21 percent of the total nitrogen load, and 22 percent of the total phosphorus load were estimated. Data for calculated and sampled individual runoff events were summed to calculate annual loads.

\section{Quality Assurance}

The quality-assurance data presented here is from the post-BMP periods only (1985-89 water years). Similar data for the pre-BMP period (1983-84 water years) can be found in Lietman and others (1996). The quality of nutrient and atrazine laboratory analyses was evaluated by the use of several types of samples. Blank samples of distilled water, routinely submitted for analysis, were used to evaluate the potential sample contamination during preparation and analysis at the laboratory. USGS round-robin standard-reference water samples (V.J. Janzer, U.S. Geological Survey, written commun., 1985-1989) were used to determine laboratory accuracy. Field-split duplicate water samples were used to measure the laboratory precision of the analysis for the individual constituents.

The Wilcoxon Signed-Rank test and the Mann-Whitney Rank Sum test were used to evaluate the nutrient data collected at all surface- and ground-water data-collection locations for the Conestoga project during the Field-Site 1 study period. Table 5 shows the constituents analyzed and summary statistics used in the qualityassurance analysis.

For each blank sample, the difference between the reported values and the detection limit was calculated for each constituent. The results of a Wilcoxon Signed-Rank test indicated that the median of the analytical concentrations of the blanks varied significantly from the detection limit at the 95-percent confidence level for total and dissolved ammonia, ammonia plus organic nitrogen, and phosphorus. This suggests either a positive bias for reported values at concentrations near reporting levels for these constituents or less than pure distilled-water blanks.

For reference samples, the Wilcoxon Signed-Rank test showed significant differences from their expected values at the 95-percent confidence level for dissolved nitrate, total ammonia, and total and dissolved phosphorus. The median difference between the laboratory and reported values for these constituents was only $0.10 \mathrm{mg} / \mathrm{L}$ or less (table 5 ).

The duplicate data were compared by use of the Mann-Whitney Rank Sum test, which compares the data as two independent groups. The results of this test showed no significant difference at the 95-percent confidence level between groups for any of the constituents; therefore, an acceptable degree of laboratory repeatability exists.

All data collected for the study were used in data analysis for this report. No corrections were made to the data. 
Table 4.--Regression statistics for suspended-sediment and total nutrient yields as a function of total runoff for all sampled storms

[Suspended-sediment yield is in tons per acre; nutrient yields are in pounds per acre of nitrogen and phosphorus; total runoff is in cubic feet per acre; all variables were log-transformed; <, less than]

\begin{tabular}{|c|c|c|c|c|c|c|c|c|c|c|}
\hline \multirow{2}{*}{ Period $^{1}$} & \multirow{2}{*}{$\begin{array}{l}\text { Dependent } \\
\text { variable }\end{array}$} & \multirow{2}{*}{$\begin{array}{l}\text { Degrees } \\
\text { of } \\
\text { freedom }\end{array}$} & \multirow{2}{*}{$\begin{array}{c}\begin{array}{c}\text { Regression } \\
\text { coefficient }\end{array} \\
\text { Log } \\
\text { of } \\
\text { total runoff }\end{array}$} & \multirow{2}{*}{ t-statistic } & \multirow{2}{*}{ p-value } & \multirow{2}{*}{ Intercept } & \multirow{2}{*}{$\begin{array}{c}\text { Coefficient } \\
\text { of } \\
\text { determination } \\
\left.\text { (adjusted } R^{2}\right)^{2}\end{array}$} & \multicolumn{3}{|c|}{$\begin{array}{l}\text { Standard error } \\
\text { of estimates, } \\
\text { in percent }^{3}\end{array}$} \\
\hline & & & & & & & & $\begin{array}{c}\text { Log } \\
\text { units }\end{array}$ & Plus & Minus \\
\hline \multicolumn{11}{|c|}{ Growing season (May through October) } \\
\hline 2 & Suspended sediment & 25 & 1.003 & 7.61 & $<0.001$ & -3.951 & 0.69 & 0.394 & 148 & 60 \\
\hline 3 & Suspended sediment & 23 & .750 & 8.37 & $<.001$ & -3.245 & .75 & .343 & 120 & 55 \\
\hline $4_{4}$ & Suspended sediment & 10 & .693 & 2.04 & .068 & -3.190 & .25 & .419 & 162 & 62 \\
\hline 2 & Total nitrogen & 23 & .920 & 6.82 & $<.001$ & -3.050 & .66 & .396 & 149 & 60 \\
\hline 3 & Total nitrogen & 22 & .848 & 11.04 & $<.001$ & -2.791 & .85 & .265 & 84 & 46 \\
\hline 4 & Total nitrogen & 8 & .780 & 5.44 & .001 & -2.370 & .78 & .174 & 49 & 33 \\
\hline 2 & $\begin{array}{l}\text { Total ammonia plus } \\
\text { organic nitrogen }\end{array}$ & 23 & .996 & 7.37 & $<.001$ & -3.550 & .70 & .397 & 149 & 60 \\
\hline 3 & $\begin{array}{l}\text { Total ammonia plus } \\
\text { organic nitrogen }\end{array}$ & 22 & .835 & 10.53 & $<.001$ & -2.924 & .83 & .273 & 88 & 47 \\
\hline 4 & $\begin{array}{l}\text { Total ammonia plus } \\
\text { organic nitrogen }\end{array}$ & 8 & .769 & 5.81 & .001 & -2.420 & .80 & .160 & 44 & 31 \\
\hline 2 & Total nitrate plus nitrite & 23 & .790 & 4.93 & $<.001$ & -3.101 & .50 & .471 & 196 & 66 \\
\hline 3 & Total nitrate plus nitrite & 22 & .891 & 9.98 & $<.001$ & -3.483 & .82 & .308 & 103 & 51 \\
\hline 4 & Total nitrate plus nitrite & 8 & .790 & 2.99 & .020 & -3.187 & .50 & .320 & 109 & 52 \\
\hline 2 & Total phosphorus & 23 & .893 & 9.02 & $<.001$ & -3.350 & .78 & .291 & 95 & 49 \\
\hline 3 & Total phosphorus & 22 & .909 & 11.19 & $<.001$ & -3.247 & .85 & .280 & 91 & 48 \\
\hline 4 & Total phosphorus & 8 & .776 & 7.09 & $<.001$ & -2.733 & .86 & .133 & 36 & 26 \\
\hline \multicolumn{11}{|c|}{ Nongrowing season (November through April) } \\
\hline 2 & Suspended sediment & 15 & 1.053 & 3.77 & .002 & -4.898 & .47 & .545 & 251 & 71 \\
\hline 3 & Suspended sediment & 16 & 1.068 & 4.83 & $<.001$ & -5.204 & .58 & .404 & 154 & 61 \\
\hline${ }^{4} 4$ & Suspended sediment & 6 & .725 & 1.55 & .18 & -3.655 & .19 & .468 & 194 & 66 \\
\hline 2 & Total nitrogen & 10 & .588 & 4.49 & .002 & -1.888 & .66 & .194 & 56 & 36 \\
\hline 3 & Total nitrogen & 10 & .817 & 7.12 & $<.001$ & -2.807 & .83 & .205 & 60 & 38 \\
\hline 4 & Total nitrogen & 5 & .798 & 3.30 & .030 & -2.526 & .66 & .235 & 72 & 42 \\
\hline 2 & $\begin{array}{l}\text { Total ammonia plus } \\
\text { organic nitrogen }\end{array}$ & 10 & .847 & 4.09 & .003 & -3.235 & .61 & .306 & 102 & 51 \\
\hline 3 & $\begin{array}{l}\text { Total ammonia plus } \\
\text { organic nitrogen }\end{array}$ & 10 & .898 & 6.25 & $<.001$ & -3.404 & .79 & .256 & 80 & 44 \\
\hline 4 & $\begin{array}{l}\text { Total ammonia plus } \\
\text { organic nitrogen }\end{array}$ & 5 & .800 & 3.08 & .037 & -2.665 & .63 & .252 & 79 & 44 \\
\hline 2 & Total nitrate plus nitrite & 10 & .497 & 1.89 & .091 & -2.011 & .20 & .389 & 145 & 59 \\
\hline 3 & Total nitrate plus nitrite & 10 & .745 & 6.96 & $<.001$ & -2.866 & .83 & .191 & 55 & 36 \\
\hline 4 & Total nitrate plus nitrite & 5 & .774 & 2.74 & .052 & -3.071 & .57 & .275 & 88 & 47 \\
\hline 2 & Total phosphorus & 10 & .753 & 4.18 & .002 & -2.844 & .62 & .266 & 84 & 46 \\
\hline 3 & Total phosphorus & 10 & .696 & 5.12 & .001 & -2.734 & .72 & .242 & 75 & 43 \\
\hline 4 & Total phosphorus & 5 & .957 & 4.18 & .014 & -3.660 & .77 & .222 & 67 & 40 \\
\hline
\end{tabular}

${ }^{1}$ Periods 2 (October 1984-September 1986), 3 (October 1986-September 1988), and 4 (October 1988-July 1989) are the post-bestmanagement practice period.

${ }^{2} R^{2}$ adjusted for degrees of freedom to allow more valid comparison between seasons.

${ }^{3}$ G.D. Tasker, U.S. Geological Survey, written commun., 1978.

${ }^{4}$ Regression not statistically significant. 


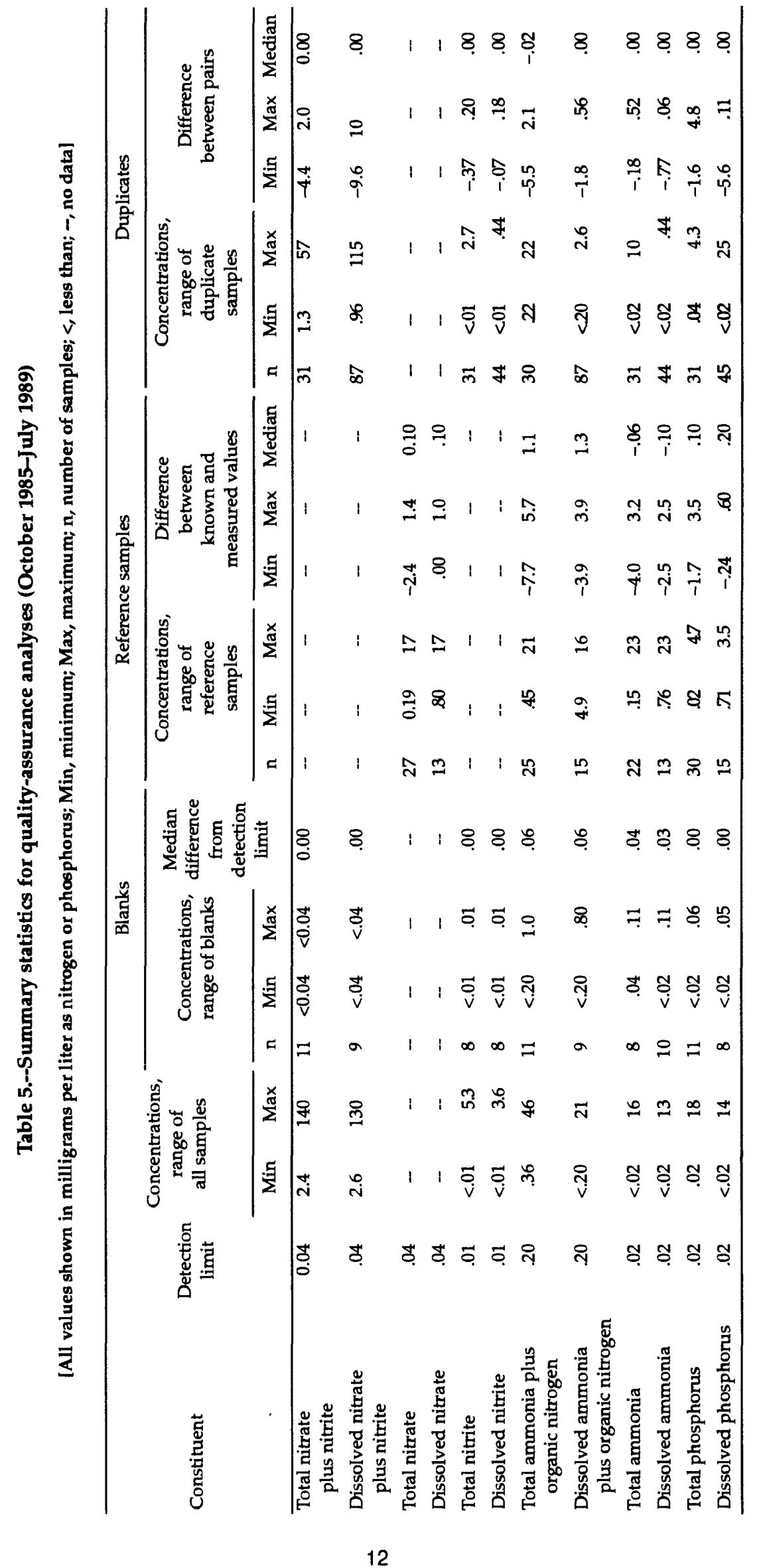




\title{
SELECTED FACTORS THAT CAN AFFECT WATER QUANTITY AND QUALITY
}

\author{
Topography, Physiography, and Geology
}

Surface elevation at Field-Site 1 ranges from $451 \mathrm{ft}$ above sea level at the eastern edge of the site to $535 \mathrm{ft}$ at its northern edge. The median slope of the land surface is about 6 percent. Localized slopes within the site changed as a result of terracing (fig. 2).

The site, located within the Piedmont Physiographic Province in the Conestoga Valley Section (U.S. Department of Agriculture, 1985), is underlain by dolomitic rocks of the Zooks Corner Formation (Cambrian age). Jointing of the rock in this area has a preferential northeast to southwest trend. A diabase dike trends east-northeast and extends approximately $300 \mathrm{ft}$ into the north-central part of the site. Soils are underlain by a 10- to 100-ft-thick weathered zone. Numerous cavities and voids, in some areas filled with silt or clay, are present at all depths in both the weathered and fresh dolomite.

A more detailed discussion of topography, physiography and geology of the site can be found in Lietman and others (1996).

\section{Climate}

Many climatologic factors influence the availability and transport of sediment and agricultural chemicals to the surface- and ground-water systems. These factors will be discussed and used to help explain water-quality characteristics.

During the post-BMP period, annual precipitation at Field-Site 1 ranged from 35.6 in. during the 1986 water year to 46.2 in. during the 1987 water year (table 6).

Normal precipitation at Field-Site 1 is about $41.5 \mathrm{in} / \mathrm{yr}$, on the basis of the 30-year average (1951-80) at Morgantown, Pa., the location of a nearby NOAA station (National Oceanic and Atmospheric Administration, 1983). The pre-BMP period, Period 1, was about 25 percent wetter than normal. On the basis of average monthly precipitation, Period 1 was about 25 percent wetter than Period 2, 19 percent wetter than Period 3, and 8 percent wetter than Period 4. Table 6 shows that Period 3 was the most comparable period to Period 1 for total precipitation; total rainfall at Field-Site 1 was slightly below normal during 1983 and 1988, and annual precipitation substantially exceeded normal during 1984 and 1987.

The distribution of monthly precipitation varied substantially from year to year and period to period (fig. 3 ). Figure 3 shows total monthly precipitation at Field-Site 1 and the 30-year monthly normal. With the exception of December, the largest year-to-year variations in total monthly precipitation occurred in the warmer months (April through September).

As soil temperatures increase, the nitrification (ammonia is converted to nitrate) and mineralization (organic nitrogen is converted to ammonia) rate of nitrogen in soils also increases. Nitrification occurs at temperatures above $40^{\circ} \mathrm{F}$, although maximum rates generally occur above $70^{\circ} \mathrm{F}$. Soil-moisture increases can also enhance nitrification, unless the soil becomes saturated, which depletes the oxygen supply (Stevenson, 1982, p. 256). These processes affect the availability of ammonia and nitrate transport by surface runoff and nitrate transport by recharge to ground-water supplies. Figure 4 shows that more precipitation occurs at temperatures favorable for nitrification and mineralization during Period 2 than during any other period, assuming that average monthly air temperatures of nearby NOAA stations generally reflect surface soil temperatures. However, moisture conditions during Period 3 were most comparable to those during Period 1 at temperatures when nitrification and mineralization would be expected to occur. 
Table 6.--Precipitation at Field-Site 1 and the 30-year mean at Morgantown, Pa.

\begin{tabular}{|c|c|c|c|}
\hline \multirow[b]{2}{*}{ Period $^{1}$} & \multirow[b]{2}{*}{ Date } & \multicolumn{2}{|c|}{ Precipitation, in inches } \\
\hline & & Field-Site 1 & $\begin{array}{c}\text { 30-year mean, } \\
\text { Morgantown } \\
(1951-80)\end{array}$ \\
\hline \multirow[t]{2}{*}{1} & Jan. 1-Sept. 30,1983 & 31.4 & 331.9 \\
\hline & Oct. 1, 1983-Sept. 30, 1984 & 59.8 & 41.5 \\
\hline \multirow[t]{2}{*}{2} & Oct. 1, 1984-Sept. 30, 1985 & 41.7 & 41.5 \\
\hline & Oct. 1, 1985-Sept. 30, 1986 & 35.6 & 41.5 \\
\hline \multirow[t]{2}{*}{3} & Oct. 1, 1986-Sept. 30, 1987 & 46.2 & 41.5 \\
\hline & Oct. 1, 1987-Sept. 30, 1988 & 41.3 & 41.5 \\
\hline 4 & Oct. 1, 1988-July 31, 1989 & 40.2 & 433.8 \\
\hline best-ma & $\begin{array}{l}\text { the pre-best-management } \\
\text { practice period. } \\
\text { the National Oceanic and } \\
\text { ar mean for months of Janu } \\
\text { ar mean for months of Octo }\end{array}$ & $\begin{array}{l}\text { riod; Period } \\
\text { Septembe } \\
\text { h July. }\end{array}$ & $\begin{array}{l}\text { and } 4 \text { are the pos } \\
\text { (1985). }\end{array}$ \\
\hline
\end{tabular}

The number and distribution of precipitation events, as well as their intensities and durations (table 7, fig. 3), affect the amounts of runoff and recharge. For this report, a storm is defined as a minimum of 0.10 in. of precipitation bounded by less than 0.014 in. of precipitation during an interval of 1 hour or more. Missing precipitation amounts, durations, and intensities were estimated where possible, and estimated values are included in figure 3 and table 7. A qualitative assessment of climatological factors during the study period indicates that Periods 1 and 3 were climatologically similar.

\section{Agricultural Activities}

Agriculture continued to be the only land use at Field-Site 1 after implementation of BMP's (nutrient management and terracing). The site is cropland that is part of each of two dairy farms. The primary crops grown throughout the study period were corn and alfalfa; soybeans and tobacco were grown in lesser amounts, and during some years, rye was used as a winter cover crop.

Substantial shifts in cropping occurred at the site through the study period. Table 8 and figure 5 show yearto-year crop acreages and summer cropping patterns for the 1983-89 crop years, defined as the interval of time beginning immediately after the harvest of 1-year's corn crop at the site and ending with the harvest of the next corn crop. During the pre-BMP period, corn was grown on about 65 percent of the site and alfalfa on 18 percent. In March 1986, as part of the terracing BMP plan, alfalfa was planted in the field downgradient of the first terrace. Period 3 was the study period most representative of the terracing BMP because terraces were settled by that period, and the planned cropping pattern was established. The plowing, planting, and harvesting time periods for corn and alfalfa are summarized in table 9. Periods 1 and 3 were similar periods on the basis of the amount of corn and alfalfa planted on the site. The corn planting and harvesting times were also about the same for Periods 1 and 3. A winter crop of rye provided soil cover during the pre-BMP period. However, during the post-BMP period, a winter cover crop was not planted except on a few acres during two winters.

Annual totals of nitrogen and phosphorus applications are tabulated by crop year rather than by water year in order to determine the amount of applied nutrients available to a season's crop with the greatest possible accuracy. 


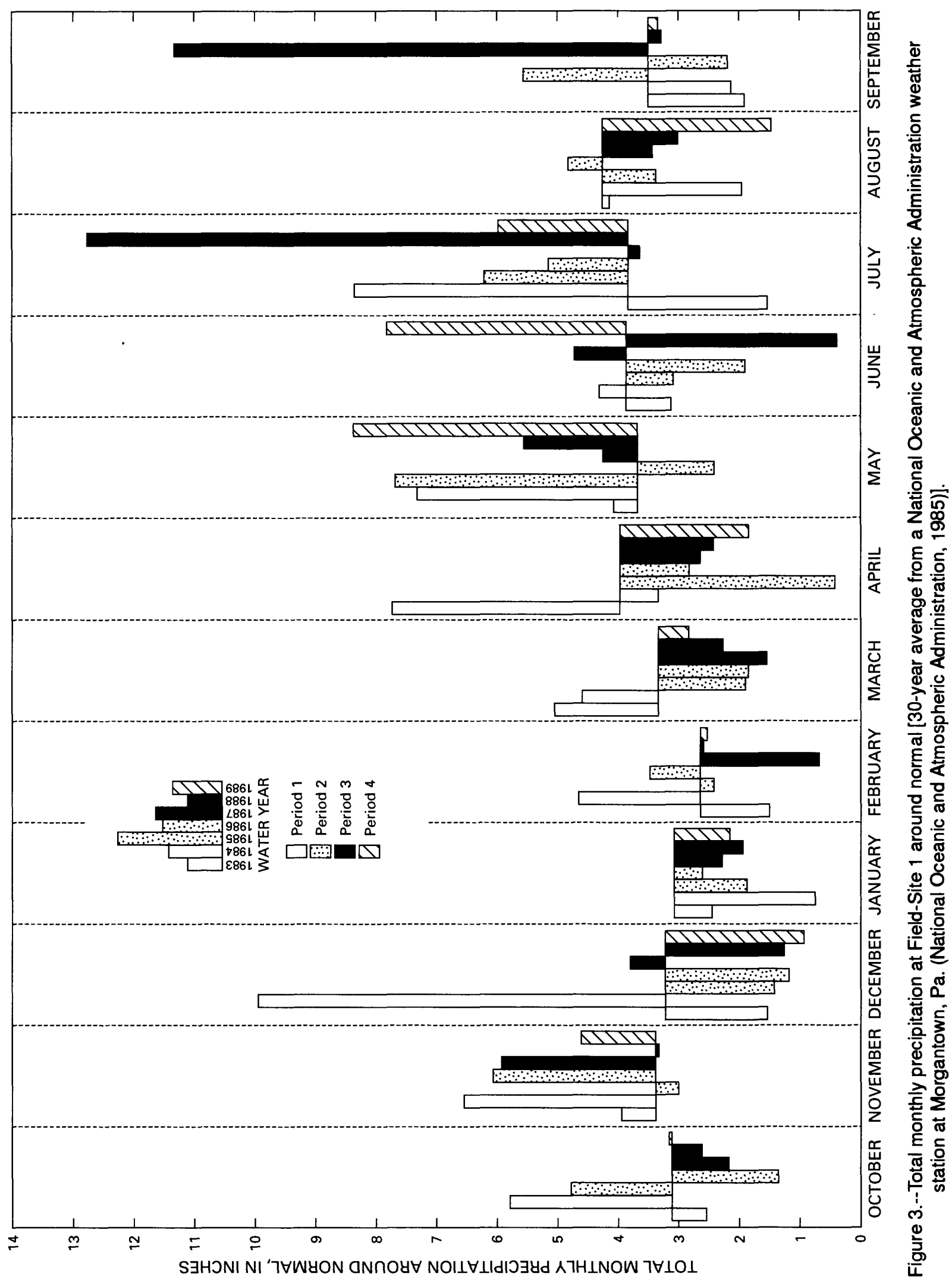




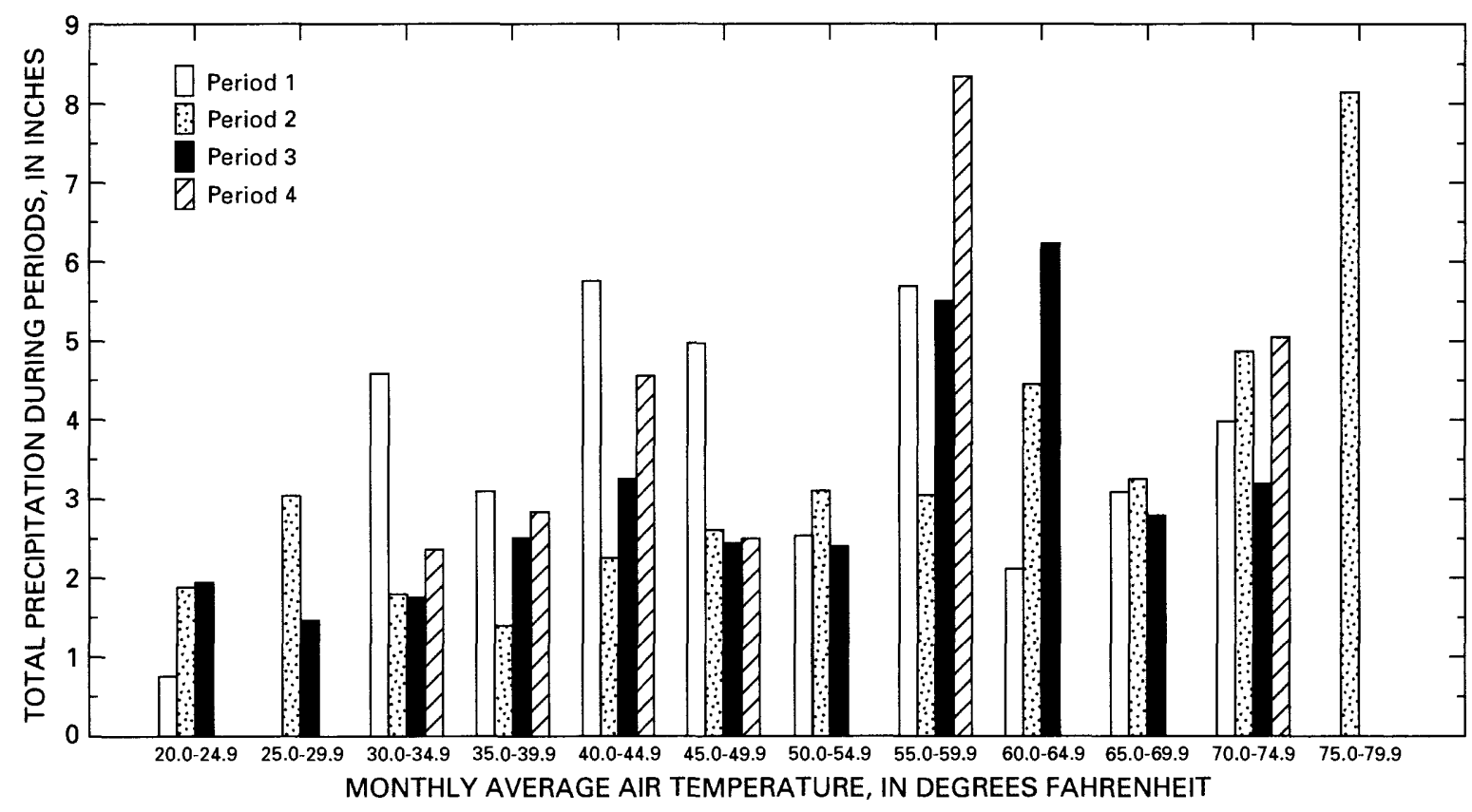

Figure 4.--Total precipitation at Field-Site 1 during each study period that occurred when the monthly average air temperature was 20 to 80 degrees Fahrenheit. [Period 1 (January 1983-September 1984) is the pre-best-management practice period; Periods 2 (October 1984-September 1986), 3 (October 1986September 1988), and 4 (October 1988-July 1989) are the post-best-management practice period.]

Table 7.--Characteristics of storms that occurred at Field-Site 1

\begin{tabular}{ccccccccc}
\hline Period $^{1}$ & $\begin{array}{c}\text { Length } \\
\text { of period, } \\
\text { in months }\end{array}$ & $\begin{array}{c}\text { Number } \\
\text { of storms }\end{array}$ & $\begin{array}{c}\text { Median } \\
\text { total storm } \\
\text { precipitation, } \\
\text { in inches }\end{array}$ & $\begin{array}{c}\text { Median } \\
\text { storm } \\
\text { duration, } \\
\text { in hours }\end{array}$ & $\begin{array}{c}\text { Median } \\
\text { maximum } \\
15 \text {-minute } \\
\text { intensity, } \\
\text { in inches }\end{array}$ & $\begin{array}{c}\text { Median } \\
\text { maximum } \\
30 \text {-minute } \\
\text { intensity, } \\
\text { in inches }\end{array}$ & $\begin{array}{c}\text { Number of storms } \\
\text { producing more } \\
\text { than 1.0 inch } \\
\text { of precipitation }\end{array}$ & $\begin{array}{c}\text { Number of storms } \\
\text { producing more } \\
\text { than 2.0 inches } \\
\text { of precipitation }\end{array}$ \\
\hline 1 & 21 & 169 & 0.29 & 2.8 & 0.08 & 0.13 & .13 & 19 \\
2 & 24 & 136 & .30 & 3.0 & .10 & .13 & 19 & 3 \\
3 & 24 & 148 & .33 & 3.4 & .07 & .10 & 24 & 6 \\
4 & 10 & 80 & .28 & 2.6 & .07 & .11 & 10 & 2 \\
\hline
\end{tabular}

${ }^{1}$ Period 1 (January 1983-September 1984) is the pre-best-management practice period; Periods 2 (October 1984-September 1986), 3 (October 1986-September 1988), and 4 (October 1988-July 1989) are the post-best-management practice period.

${ }^{2}$ For this report, a storm is defined as a minimum of 1.10 inches of precipitation bounded by less than 0.014 inch of precipitation during an interval of 1 hour or more.

${ }^{3}$ The largest storm recorded during the 79-month study period occurred on September 8,1987 , and produced 6.70 inches of rain in an 11-hour period.

Table 8.--Crops and acreage at Field-Site 1 for the 1983-89 crop years

\begin{tabular}{lrrrrrrr}
\hline \multirow{2}{*}{ Crop } & \multicolumn{7}{c}{ Acreage, in crop years } \\
\cline { 2 - 8 } & 1983 & 1984 & 1985 & 1986 & 1987 & 1988 & 1989 \\
\hline Corn & 14.4 & 14.4 & 17.9 & 13.3 & 14.2 & 15.4 & 7.3 \\
Alfalfa & 5.4 & 5.4 & 4.2 & 8.8 & 7.7 & 7.7 & 14.2 \\
Soybeans & .0 & .0 & .0 & .8 & 1.1 & .0 & 1.6 \\
Tobacco & 1.9 & .0 & 1.0 & .2 & .0 & .0 & .0 \\
Rye & .0 & 1.9 & .0 & .0 & .0 & .0 & .0 \\
Pumpkins & .4 & .4 & .0 & .0 & .0 & .0 & .0 \\
\hline
\end{tabular}




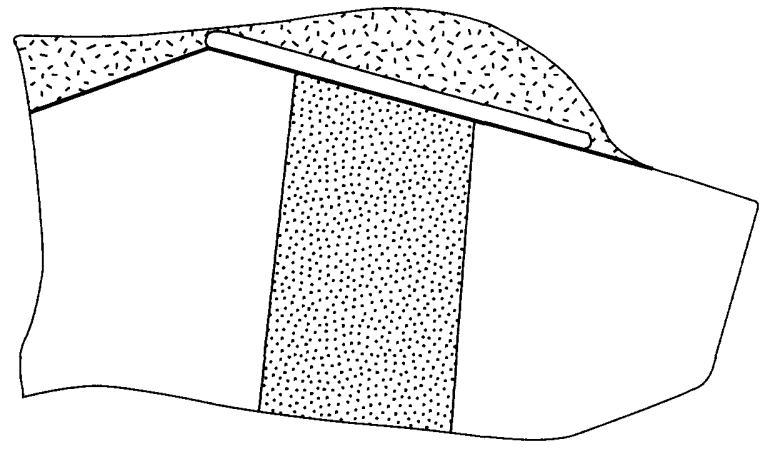

1983 and 1984

CORN, 65 PERCENT

ALFALFA, 25 PERCENT

OTHER, 10 PERCENT

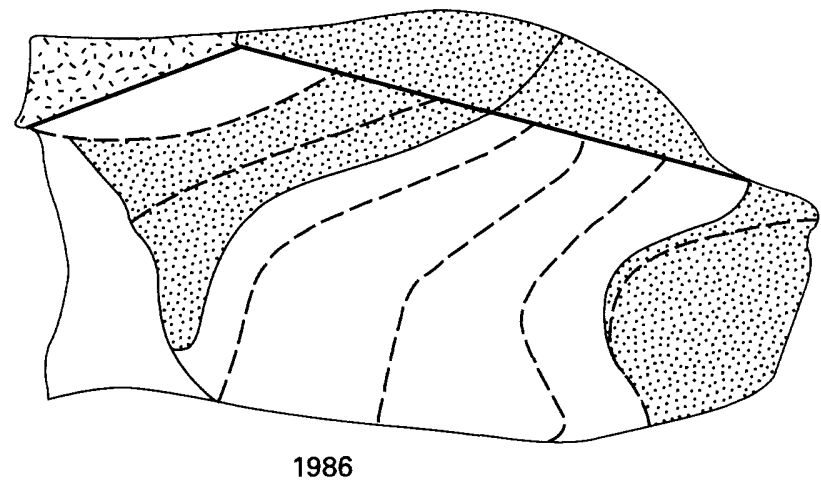

CORN, 58 PERCENT

ALFALFA, 38 PERCENT

OTHER, 4 PERCENT

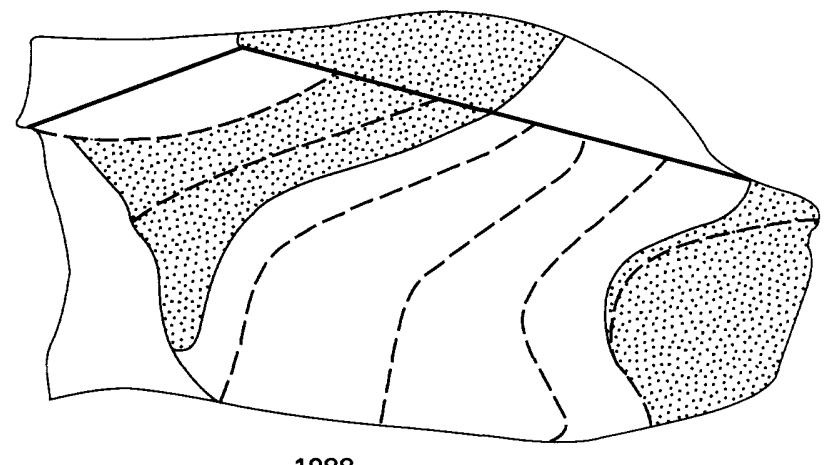

1988

CORN, 67 PERCENT

ALFALFA, 33 PERCENT OTHER, O PERCENT

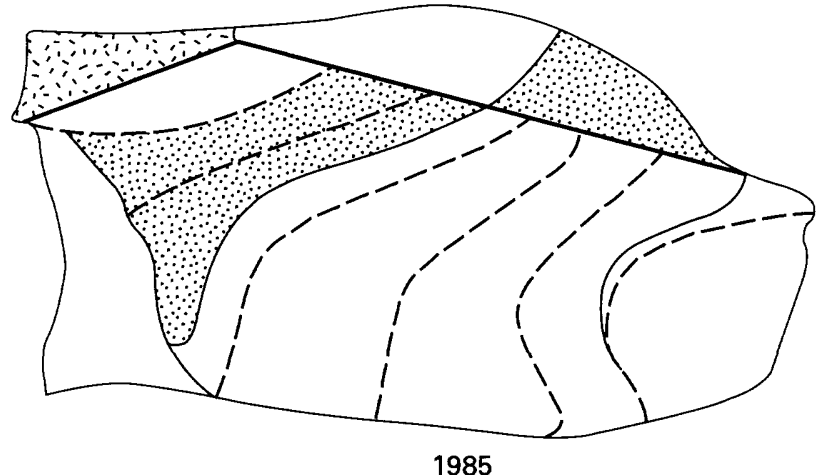

CORN, 77 PERCENT

ALFALFA, 18 PERCENT

OTHER, 5 PERCENT

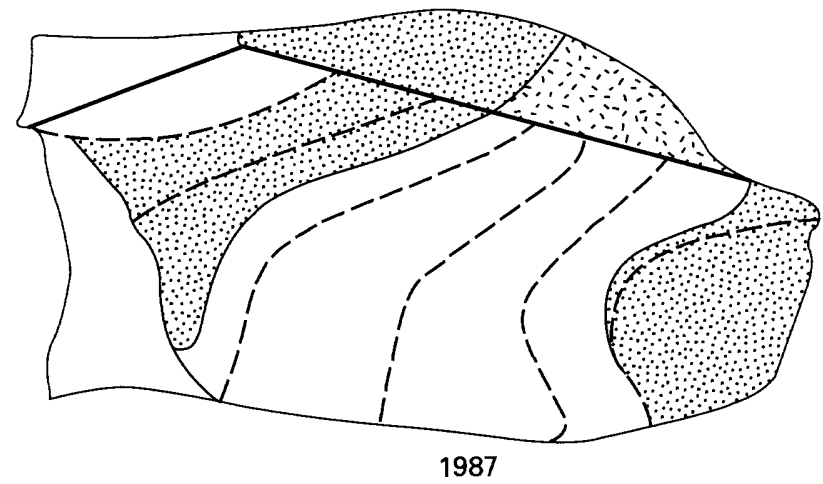

CORN, 62 PERCENT

ALFALFA, 33 PERCENT

OTHER, 5 PERCENT

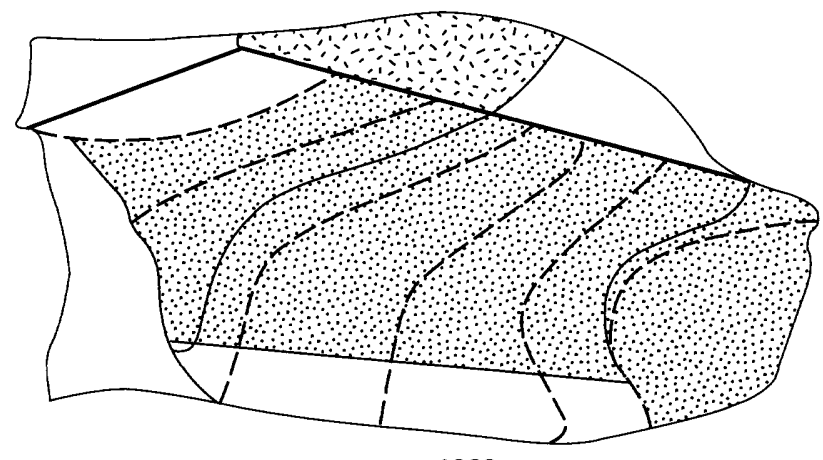

1989

CORN, 32 PERCENT

ALFALFA, 61 PERCENT

OTHER, 7 PERCENT

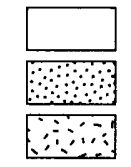

CORN

ALFALFA

OTHER

- - - - TERRACE CREST

Figure 5.--Cropping patterns at Field-Site 1 for the $1983-89$ crop years. (See figure 2 for detailed map of site.) 
Table 9.--Schedule of plowing, planting, and harvesting ${ }^{1}$ at Field-Site 1

[R, rye winter cover crop plant on cornfields; $C$, cornfields plowed and corn planted; $H$, corn harvested; A, new alfalfa fields plowed and planted]

\begin{tabular}{|c|c|c|c|c|c|c|c|c|c|c|c|c|c|}
\hline Year & \begin{tabular}{c|c|} 
JAN \\
$1-15$ & $16-31$
\end{tabular} & \begin{tabular}{|c|c|} 
FEB \\
1-15 & $16-29$
\end{tabular} & \begin{tabular}{|c|c|} 
MAR \\
$1-15$ & $16-31$ \\
\end{tabular} & \begin{tabular}{|c|c|} 
APR \\
$1-15$ & $16-30$
\end{tabular} & $\begin{array}{r}\text { MA } \\
1-15 \mid 1\end{array}$ & $\begin{array}{l}4 Y \\
16-31\end{array}$ & $\begin{array}{c}\text { JUNE } \\
1-15 \mid 16-30\end{array}$ & \begin{tabular}{|c|c|} 
JULY \\
1-15 & $16-31$ \\
\end{tabular} & \begin{tabular}{|c|c|}
\multicolumn{1}{|c|}{ AUG } \\
$1-15$ & $16-31$ \\
\end{tabular} & \begin{tabular}{|c|c|} 
SEPT \\
$1-15$ & $16-30$ \\
\end{tabular} & \begin{tabular}{|c|c|} 
OCT \\
$1-15$ & $16-31$ \\
\end{tabular} & \begin{tabular}{c|c|} 
NOV \\
$1-15$ & $16-30$
\end{tabular} & $\begin{array}{c}\text { DEC } \\
1-15 \mid 16-31\end{array}$ \\
\hline 1982 & & & & & & & & & & & $\overline{\mathrm{R}}$ & & \\
\hline 1983 & & & & & C & & & & & $\mathrm{H}$ & R & & \\
\hline 1984 & & & & & C & & & & & $H$ & Terracec & & \\
\hline 1985 & & & A & & & & C & & & & $H$ & & \\
\hline 1986 & & & A & C & & & & & & $H$ & & & \\
\hline 1987 & & & & C & C & & & & & & H & & \\
\hline 1988 & & & & & C & C & & & & $H$ & & & \\
\hline 1989 & & & & A & & C & & & & & & & \\
\hline
\end{tabular}

Manure from dairy cattle was the primary nutrient source applied to the site, comprising 93 and 84 percent of the total nitrogen and phosphorus applications, respectively, during the post-BMP period. Commercial fertilizer comprised the remainder. The manure storage pit was not ready for use during the 1985 crop year. Fertilizer applied to the site during the 1985 crop year was a mixture of commercial fertilizer and heifer manure; the nitrogen and phosphorus content of the heifer manure was 6.50 and $1.88 \mathrm{lb} /$ ton, respectively. Results of nutrient analysis of manure samples, collected from 1986 through 1988, varied by up to 25 percent from sample to sample because of factors such as variable moisture content and feeds, in addition to sample-collection and analysis variability. An average content of nitrogen and phosphorus was used for the post-BMP period to estimate the nutrient value of manure. The average nitrogen and phosphorus content of heifer manure was 12.1 and $2.95 \mathrm{lb} /$ ton, respectively; the average nitrogen and phosphorus content of the dairy (pit) manure was 2.48 and $0.71 \mathrm{lb} / 100 \mathrm{gal}$, respectively. These average contents were multiplied by the amounts of manure applied to estimate nutrient loads to the fields during the 1986 through 1989 crop years. The average annual nitrogen and phosphorus applications to the site were about $270 \mathrm{lb} /$ acre of nitrogen and $70 \mathrm{lb} / \mathrm{acre}$ of phosphorus for both the pre- and post-BMP periods.

Distribution and timing of manure applications is an important factor to consider when implementing a nutrient-management practice. Figure 6 shows the monthly total amounts of nitrogen and phosphorus as manure or commercial fertilizer applied to the site during the pre- and post-BMP study periods. Applications were made less frequently during the post-BMP period than the pre-BMP period. During the post-BMP period, the majority of the pit manure (dairy manure and wash water from the manure storage pit) was generally applied to the fields in the springtime soon before plowing and planting; another application was usually made after crop harvest in the fall. During the 1985,1986 , and 1988 crop years, most of the nutrients $(74,81$, and 92 percent, respectively) were applied after January 1, usually just before the fields were plowed. During the 1987 and 1989 crop years, 54 and 6 percent of the nutrients were applied after January 1, respectively. The heifer manure was not incorporated into the storage facility and continued to be spread periodically. During the pre-BMP period, manure was applied almost every month crops were not growing on the field, including months when the soil was frozen. The construction of the manure storage pit allowed applications to be made less frequently and when soil conditions were favorable. Period 3 was most comparable to Period 1 with respect to the timing of nutrient applications; 1987 was most comparable to 1984, and 1988 was most comparable to 1983 when no applications were made to the field after the previous fall harvest. 

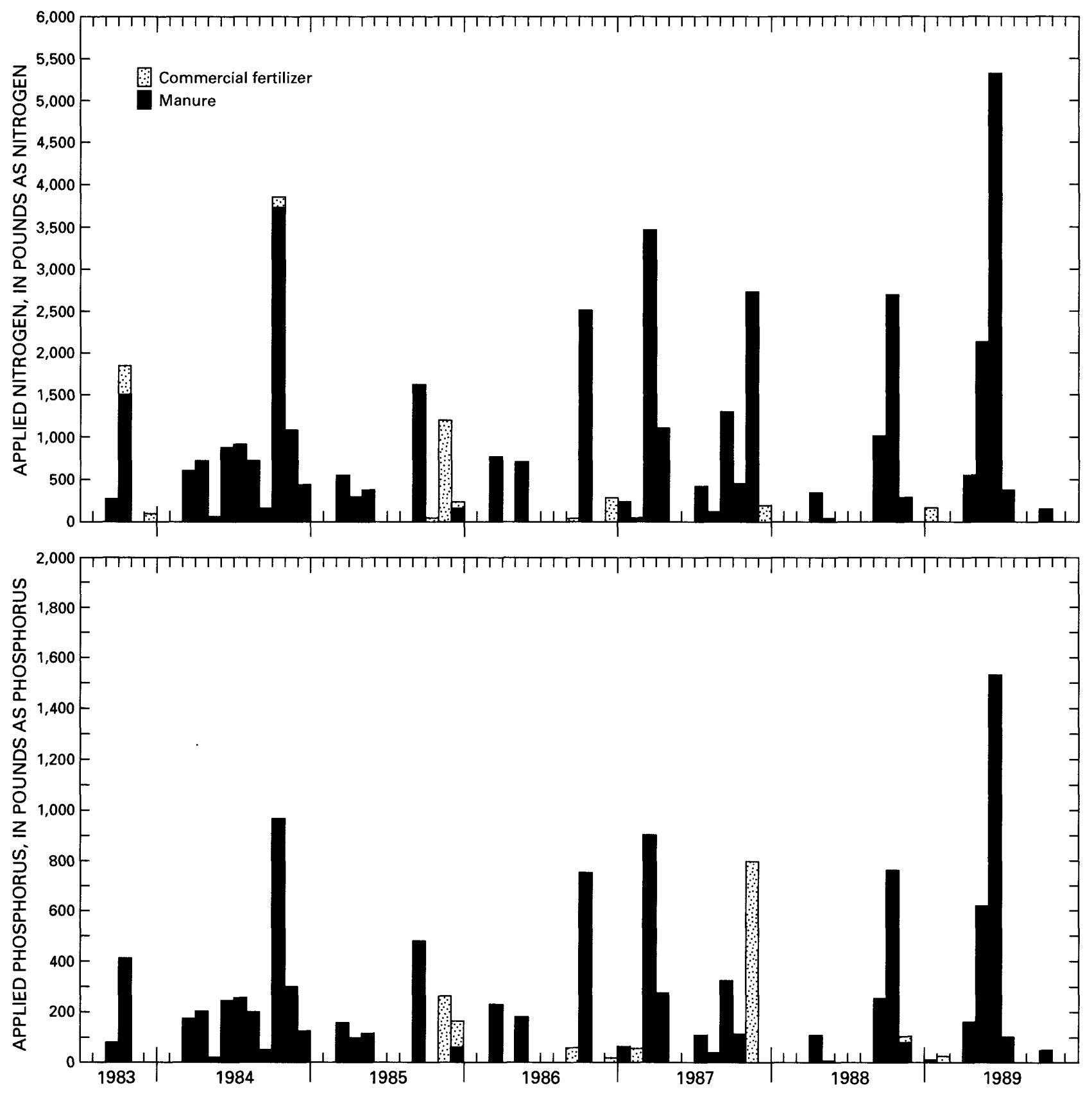

Figure 6.--Monthly nitrogen and phosphorus applications to Field-Site 1.

Figure 7 and table 10 show nutrient-application rates in pounds per acre to the individual fields and illustrate the uneven nutrient applications. Because crop boundaries do not always coincide with field boundaries, rates of applied nitrogen and phosphorus reflect the spacial and temporal distribution, not the application rates per crop. For example, Field 5 was divided into a 1.3-acre alfalfa section that received an annual average of $53 \mathrm{lb} /$ acre of nitrogen and a 1.4-acre corn section that received an annual average of $230 \mathrm{lb} / \mathrm{acre}$ of nitrogen, giving an annual average "per field" application rate for the post-BMP period of $137 \mathrm{lb} / \mathrm{acre}$ of nitrogen. 


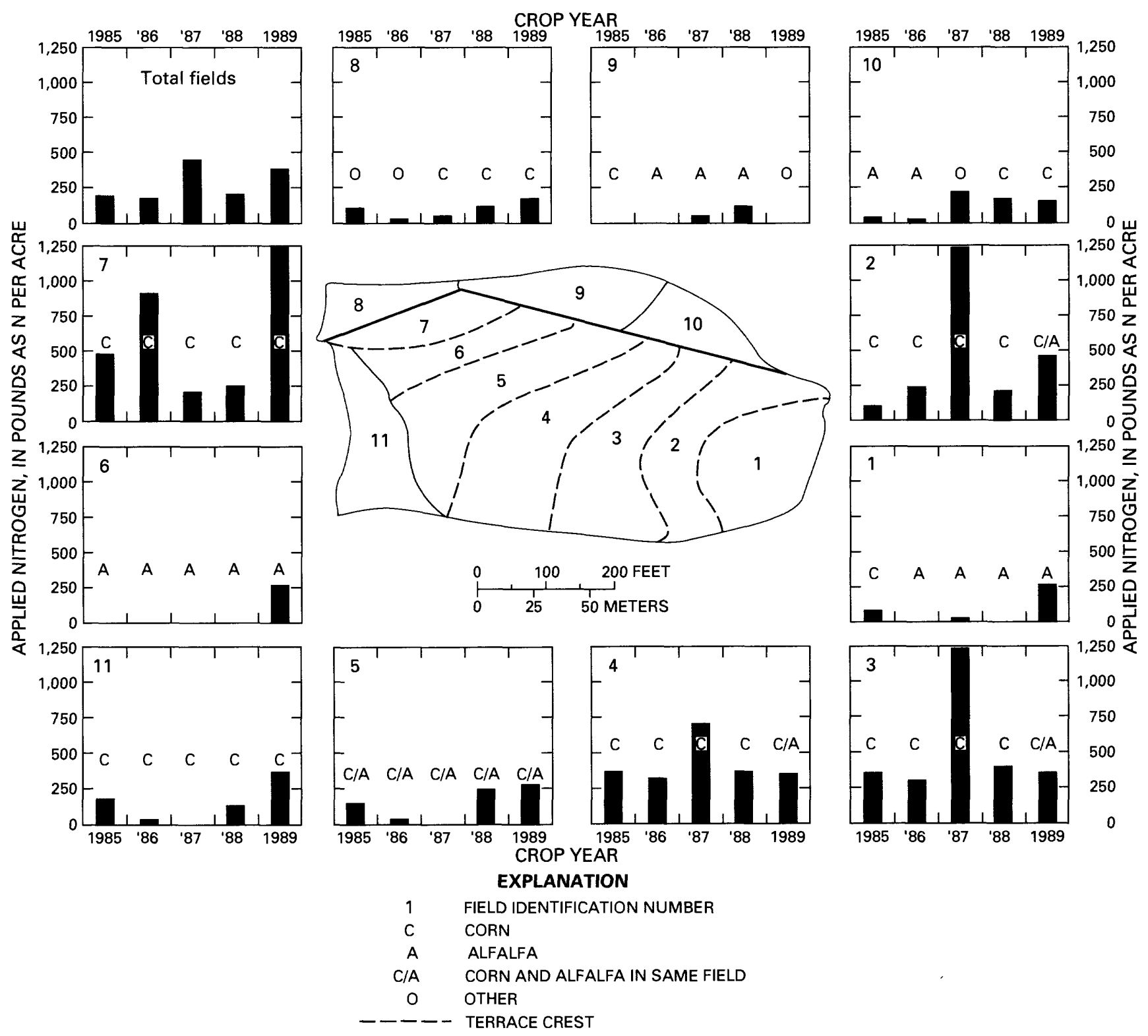

Figure 7.--Nitrogen-application rates for each field at Field-Site 1 for crop years 1985-89. (See figure 2 for detailed map of site.)

Nitrogen and phosphorus were spacially distributed about the same on the site because most of the nutrients were from manure. The largest nutrient applications per crop year were made for the $1987 \mathrm{crop}$, $432 \mathrm{lb} /$ acre of nitrogen and $80 \mathrm{lb} /$ acre of phosphorus, average for the site. However, distribution across the site varied dramatically from year to year and field to field (fig. 7). Fields 8-10, managed by a different farmer than the other fields, generally had substantially smaller nutrient applications than the other fields. Fields $2,3,4$, and 7 generally had larger applications than the other fields. Nitrogen applications of more than 1,000 lb/acre were made to Fields 2 and 3 for the 1987 crop and Field 7 for the 1989 crop.

Manure applications were concentrated on the corn acreage, whereas the alfalfa acreage received relatively small applications (table 11), predominantly in the form of commercial fertilizer. The nitrogen and phosphorus applications made to corn and alfalfa varied dramatically, however, from one crop year to another. For example, for the 1987 corn crop, $685 \mathrm{lb} /$ acre of nitrogen was applied, but for the 1985 corn crop, only $230 \mathrm{lb} / \mathrm{acre}$ of nitrogen was applied. 
Table 10.--Nitrogen and phosphorus applied to Field-Site 1 during the post-best-management practice period (October 1984-July 1989)

[All applications are in pounds per acre per crop year; $N$, nitrogen; $P$, phosphorus]

\begin{tabular}{|c|c|c|c|c|c|c|c|c|c|c|c|}
\hline \multirow{2}{*}{ Field } & \multirow{2}{*}{ Acres } & \multicolumn{2}{|c|}{1985} & \multicolumn{2}{|c|}{1986} & \multicolumn{2}{|c|}{1987} & \multicolumn{2}{|c|}{1988} & \multicolumn{2}{|c|}{1989} \\
\hline & & $\mathrm{N}$ & $P$ & $\mathrm{~N}$ & $P$ & $\bar{N}$ & $P$ & $\bar{N}$ & $P$ & $\mathrm{~N}$ & $\bar{P}$ \\
\hline 1 & 2.5 & 70 & 20 & 0 & 0 & $\overline{16}$ & 0 & 0 & 0 & 260 & $\overline{76}$ \\
\hline 2 & 2.5 & 120 & 21 & 240 & 63 & 1,230 & 320 & 220 & 64 & 460 & 130 \\
\hline 3 & 3.1 & 340 & 93 & 300 & 79 & 1,220 & 320 & 400 & 110 & 360 & 83 \\
\hline 4 & 3.7 & 360 & 92 & 300 & 79 & 701 & 190 & 360 & 96 & 360 & 81 \\
\hline 5 & 2.7 & 140 & 41 & 25 & 3 & 0 & 0 & 240 & 63 & 270 & 77 \\
\hline 6 & 1.8 & 0 & 0 & 0 & 0 & 0 & 0 & 0 & 0 & 270 & 76 \\
\hline 7 & 1.1 & 480 & 130 & 920 & 234 & 200 & 58 & 260 & 74 & 2,060 & 590 \\
\hline 8 & .9 & 90 & 40 & 14 & 8 & 37 & 18 & 100 & 18 & 170 & 39 \\
\hline 9 & 1.6 & 0 & 0 & 30 & 48 & 110 & 0 & 0 & 0 & 0 & 0 \\
\hline 10 & 1.1 & 20 & 59 & 15 & 26 & 200 & 0 & 190 & 37 & 150 & 43 \\
\hline 11 & 2.0 & 190 & 54 & 30 & 3 & 0 & 0 & 120 & 36 & 360 & 98 \\
\hline
\end{tabular}

Table 11.--Nutrient applications to Field-Site 1 by crop

[All applications are in pounds per acre]

\begin{tabular}{lccccc}
\hline \multirow{2}{*}{$\begin{array}{l}\text { Crop } \\
\text { year }\end{array}$} & \multicolumn{2}{c}{ Corn } & \multicolumn{3}{c}{ Alfalfa } \\
\cline { 2 - 3 } \cline { 5 - 6 } & Nitrogen & Phosphorus & & Nitrogen & Phosphorus \\
\hline 1983 & 150 & 33 & & 0 & 0 \\
1984 & 640 & 170 & 31 & 8 \\
1985 & 230 & 61 & 9 & 15 \\
1986 & 290 & 72 & 7 & 12 \\
1987 & 690 & 130 & 24 & 0 \\
1988 & 300 & 80 & 0 & 0 \\
1989 & 540 & 160 & 290 & 84 \\
\hline
\end{tabular}

Period 3 was the post-BMP period most comparable to Period 1 with respect to crops and nutrient applications to the site. During both periods, an average of 65 percent of the site was planted in corn. The corn planting and harvesting times were about the same in Periods 3 and 1. A winter cover crop was planted during both years of the pre-BMP period, but little winter cover crop was planted during the post-BMP period. The average applications for the site were about $320 \mathrm{lb} /$ acre of nitrogen and $82 \mathrm{lb} /$ acre of phosphorus during Period 3, and $270 \mathrm{lb} /$ acre of nitrogen and $70 \mathrm{lb} /$ acre of phosphorus during Period 1.

The nutrient-management plans are based on nitrogen applications only and, as a result, recommended an excess of phosphorus when manure was used to meet the nitrogen requirements of crops. The nutrientmanagement plan, developed in 1985 for Fields 1-7 and 11, recommended an annual nitrogen application rate of 350-375 lb/acre of nitrogen within 5-7 days of plowing of cornfields (less than a 15-percent reduction from that applied during the pre-BMP period). In addition, the plan recommended an average application rate of $100 \mathrm{lb} /$ acre of nitrogen for newly seeded alfalfa fields (with no application recommended on established alfalfa). With the manure incorporated into the soil by plowing 5-7 days after application, and considering 
the nitrogen available from previous years' applications, approximately 65 percent of the nitrogen applied should be available for the crop (includes 30 percent from the present application and 35 percent from applications for previous years) [estimated from information from the Penn State Agronomy Guide (Pennsylvania State University, 1987)]. The phosphorus in manure is considered to be available the year of application (Robert Anderson, Pennsylvania State University, Lancaster County Cooperative Extension Service Nutrient Management Office, written commun., 1985). The nutrient-management plan that was revised for the 1989 crop year made almost the same recommendations for the corn crop and about 1.5 times the 1985 recommendation for new alfalfa. The largest manure applications during the post-BMP period generally were made a few days to weeks before plowing in the spring.

The agricultural-activities data collected from the farmer are not accurate enough to determine the specific number of days between applications and plowing (incorporation). The data, however, do indicate that at least in 1986 and 1988, the large pit-manure applications were made in the spring within 1-2 days of plowing, which increases the available nitrogen from 65 to 85 percent [estimated by the use of information from the Penn State Agronomy Guide (Pennsylvania State University, 1987)].

Although the average rate calculated for the post-BMP period does fall within the range recommended, it should be noted that distribution of applications were not consistent throughout the pre- or post-BMP periods. Nutrient-management recommendations were followed within 25 percent in the 1985, 1986, and 1988 crop years; applications were adjusted for rapid incorporation of a substantial part of the manure in 1986 and 1988 . However, the planned applications were exceeded by about 2.5 times in 1987 and 1989 crop years.

Herbicides were applied primarily to the cornfields throughout the 79-month study period. The primary herbicides that were used and that were analyzed for in water and soil samples were atrazine, metolachlor, and cyanazine. In addition, simazine was applied to the alfalfa in December 1987. Table 12 shows the quantities and years of application.

Table 12.--Herbicides applied to Field-Site 1, as reported by farmers

[Herbicides, in pounds]

\begin{tabular}{lrrrrrrrr}
\hline \multirow{2}{*}{ Herbicide } & \multicolumn{7}{c}{ Water year } \\
\cline { 2 - 8 } & 1983 & 1984 & 1985 & 1986 & 1987 & 1988 & 1989 \\
\hline Atrazine $^{1}$ & 14 & 26 & 6 & 14 & 11 & 7 & 3 \\
Metolachlor $^{1}$ & 22 & 34 & 8 & 17 & 0 & 2 & 12 \\
Cyanazine $^{1}$ & 0 & 0 & 0 & 0 & 23 & 13 & 6 \\
Simazine $^{2}$ & 0 & 0 & 0 & 0 & 8 & 0 & 0 \\
\hline \multicolumn{1}{c}{ 1 Applied to cornfields in May or June. $^{2}$ Applied to alfalfa in December. }
\end{tabular}

\section{Soils}

Soils at the site are classified as Duffield and Hagerstown silt loams. These soils typically are deep, well drained, and form in residuum of weathered carbonate rocks. General soil characteristics at the site are discussed in detail in Lietman and others (1996). The nutrient and herbicide data presented in this report are used to help characterize the soil at the site during the post-BMP period and to contrast the post-BMP data to pre-BMP data in relation to factors affected by BMP implementation. Statistical comparisons are not made because of the limited number of samples and the large variability in the data. 
Median, minimum, and maximum concentrations of nutrients in the soil from cornfields 3 and 4 and alfalfa field 5 are shown in table 13. Median soil concentrations of nitrate for the corn or alfalfa fields ranged from 16 to $39 \mathrm{lb} /$ acre for the 0-8-in. depth (the plow layer), from 11 to $50 \mathrm{lb} /$ acre for the 8-24-in. depth, and from 7 to $48 \mathrm{lb} /$ acre for the $24-48$-in. depth. The median nitrate available in the entire corn root zone, $0-48$-in. depth, ranged from 45 to $104 \mathrm{lb} /$ acre. Median concentrations of phosphorus in the soil from the corn or alfalfa fields ranged from 0.5 to $2.5 \mathrm{lb} /$ acre for $0-8$-in. depth, 0.2 to $0.5 \mathrm{lb} /$ acre for the 8-24-in. depth and from 0.2 to $0.4 \mathrm{lb}$ /acre to the $24-48$-in. depth. (Reported phosphorus concentrations may be converted to $\mathrm{P}_{2} \mathrm{O}_{5}$ by multiplying the phosphorus concentrations by 2.3.)

Table 13.--Summary statistics of nutrient data for soil samples collected at Field-Site 1 from November 1984 through June 1989

INo samples were collected during the spring of 1985 and 1989 and during the summer of 1985;

Med, median; Min, minimum; Max, maximum; --, no datal

\begin{tabular}{|c|c|c|c|c|c|c|c|c|c|}
\hline \multirow{2}{*}{$\begin{array}{l}\text { Sampling } \\
\text { period }\end{array}$} & \multirow{2}{*}{$\begin{array}{c}\text { Depth, } \\
\text { in inches }\end{array}$} & \multicolumn{4}{|c|}{ Corn (Fields 3 and 4) } & \multicolumn{4}{|c|}{ Alfalfa (Field 5) } \\
\hline & & $\begin{array}{l}\text { Number } \\
\text { of samples }\end{array}$ & Med & Min & Max & $\begin{array}{l}\text { Number } \\
\text { of samples }\end{array}$ & Med & Min & Max \\
\hline \multicolumn{10}{|c|}{ Nitrate, in pounds per acre as $\mathrm{N}$} \\
\hline \multirow[t]{3}{*}{ Fall } & $0-8$ & 10 & 33 & 15 & 115 & 3 & 19 & 12 & 23 \\
\hline & $8-24$ & 10 & 24 & 11 & 65 & 3 & 11 & 9.1 & 13 \\
\hline & $24-48$ & 10 & 34 & 13 & 39 & 3 & 27 & 11 & 42 \\
\hline \multirow[t]{3}{*}{ Spring } & $0-8$ & 8 & 16 & 13 & 29 & 3 & 20 & 18 & 33 \\
\hline & $8-24$ & 8 & 28 & 24 & 75 & 3 & 16 & 13 & 20 \\
\hline & $24-48$ & 8 & 48 & 14 & 166 & 3 & 7 & 6 & 15 \\
\hline \multirow[t]{3}{*}{ Summer } & $0-8$ & 8 & 39 & 11 & 112 & 4 & 28 & 13 & 39 \\
\hline & $8-24$ & 8 & 50 & 6.7 & 174 & 4 & 26 & 13 & 44 \\
\hline & $24-48$ & 0 & -- & - & - & 0 & - & - & - \\
\hline \multicolumn{10}{|c|}{ Phosphorus, in pounds per acre as $P$} \\
\hline \multirow[t]{3}{*}{ Fall } & $0-8$ & 10 & 1.2 & .4 & 3.9 & 3 & 2.5 & 1.8 & 3.5 \\
\hline & $8-24$ & 10 & .3 & .2 & .6 & 3 & .5 & .2 & .6 \\
\hline & $24-48$ & 10 & .4 & .2 & 1.1 & 3 & .2 & .2 & 1.0 \\
\hline \multirow[t]{3}{*}{ Spring } & $0-8$ & 8 & .5 & .1 & 1.7 & 3 & 2.0 & .5 & 3.2 \\
\hline & $8-24$ & 8 & .2 & .2 & 1.2 & 3 & .2 & .2 & .2 \\
\hline & $24-48$ & 8 & .3 & .2 & 1.7 & 3 & .2 & .2 & .4 \\
\hline \multirow[t]{3}{*}{ Summer } & $0-8$ & 8 & .9 & .1 & 11 & 4 & 1.0 & .5 & 2.0 \\
\hline & $8-24$ & 8 & .3 & .2 & 2.3 & 4 & .3 & .1 & .6 \\
\hline & $24-48$ & 0 & - & - & - & 0 & - & - & - \\
\hline
\end{tabular}

Median concentrations of nitrate for the 0-8- and 8-24-in. depths are greater in the summer than in the fall or spring for both corn and alfalfa fields and were greater in soil samples from the cornfields than from the alfalfa field, except for the 0-8-in. depth during the spring sampling period. Except for two soil samples collected in the fall of 1985 at cornfield 3 and in the summer of 1986 at cornfield 4, the nitrate concentrations were greater in the 0-8-in. samples than the 8-24-in. samples. Soil data from the cornfield indicate a general downward movement of nitrate during the winter, which is reflected in a reduced nitrate concentration in the 0-8-in.-deep soil layer and increased variability in nitrate concentrations in the deeper soil layers sampled in the spring. However, concentrations of nitrate decreased with depth in soil samples collected in the spring from the alfalfa field. 
The soluble phosphorus concentrations were larger in the 0-8-in. soil samples than in the deeper soil samples, except for one, regardless of site or season. The phosphorus concentrations in samples below 8 in. were generally less than 0.05 (lb/in)/acre. Median phosphorus concentrations for each depth interval sampled were greater in the fall samples and for the 0-8-in. depth; median phosphorus concentrations were less in samples from the cornfields than from the alfalfa field.

The higher nitrate [4-14 (lb/in)/acre] and phosphorus [0.10-1.4 (lb/in)/acre] concentrations in the shallow soil samples from cornfields were all measured after the large applications for the 1987 crop (table 10). In contrast, the variation in nutrient concentrations in the alfalfa field did not appear to be related to variations in applications.

The average concentration of dissolved nitrate and dissolved phosphorus in the top 8 in. of soil in the spring of 1984 was 20 and $0.5 \mathrm{lb}$ /acre, respectively; these concentrations were representative of the entire site (Lietman and others, 1996). Although nutrient concentrations in soils differed widely, limited data suggest that median concentrations did not vary substantially during the post-BMP period. Median concentrations of dissolved nitrate of $16 \mathrm{lb} /$ acre in cornfields and $20 \mathrm{lb} / \mathrm{acre}$ in the alfalfa field, and median concentrations of dissolved phosphorus of $0.5 \mathrm{lb} /$ acre in cornfields and $2.0 \mathrm{lb} /$ acre in the alfalfa field were measured in soil samples collected each spring during the post-BMP period (1985-89). This would be expected because overall nutrient applications changed very little from the pre-BMP to post-BMP period. During terracing, the soil was mixed and redistributed. However, this did not appear to affect soil nutrient concentrations.

In the top $2 \mathrm{ft}$ of soil, the median concentration of nitrate in the soil (one sample from each of the two cornfields and one sample from the alfalfa field) during the fall of 1983 (the pre-BMP period) was about $60 \mathrm{lb} / \mathrm{acre}$ (Lietman and others, 1996). This is about the same as the post-BMP period, when a median concentration of $65 \mathrm{lb} /$ acre in the cornfields and $32 \mathrm{lb} /$ acre in the alfalfa field was measured.

Atrazine concentrations in composite samples of the top 2 in. of soil from 13 locations distributed over the site were greatest after spring application and lowest in the fall and spring (fig. 8). Concentrations of atrazine ranged from less than 20 to $720 \mu \mathrm{g} / \mathrm{kg}$. Metolachlor in soils was analyzed for only after September 1985. Metolachlor, applied each spring to the cornfields, except in 1987, was detected in three of six samples; the concentrations were $30 \mu \mathrm{g} / \mathrm{kg}$ in October 1985, $900 \mu \mathrm{g} / \mathrm{kg}$ in May 1986, and $20 \mu \mathrm{g} / \mathrm{kg}$ in September 1986. Cyanazine, applied to the cornfields only in the spring of 1987, was measured in one sample at a concentration of $430 \mu \mathrm{g} / \mathrm{kg}$ in June 1989. Although not reportedly applied to the site during the study period, alachlor, at a concentration of $50 \mu \mathrm{g} / \mathrm{kg}$, and simazine, at a concentration of $120 \mu \mathrm{g} / \mathrm{kg}$, were measured in the May 1986 soil samples.

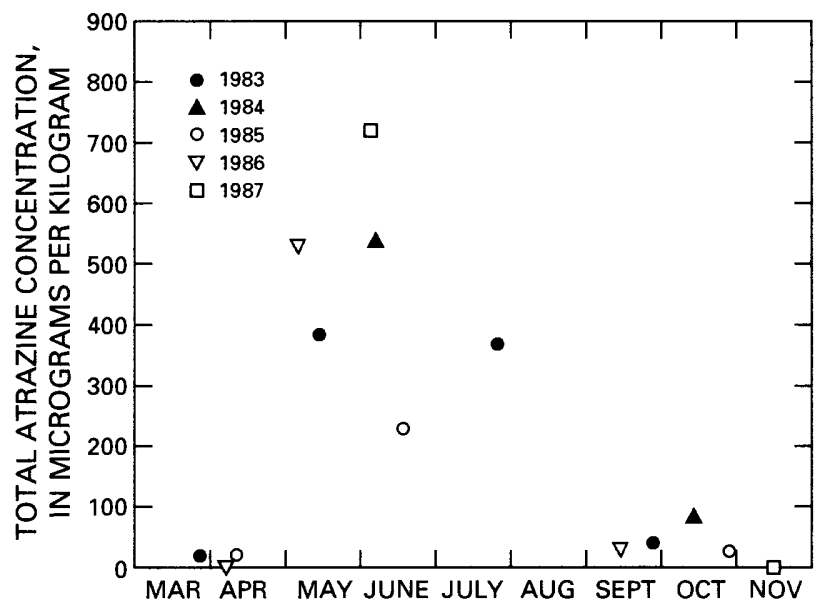

Figure 8.--Concentrations of atrazine in composite soil samples of the top 2 inches at Field-Site 1. 


\section{EFFECTS OF PIPE-OUTLET TERRACING ON QUANTITY AND QUALITY OF SURFACE RUNOFF}

Surface runoff during the pre-BMP period was unimpeded by structural devices, and as a result, small feeder gullies and larger receiving gullies were created over much of the area planted in corn (fig. 5). In contrast, most surface runoff during the post-BMP period, after installation of the terraces, discharged through the pipe-outlet system. Twice, under extreme storm conditions, runoff breached the terrace structures. Measurable runoff from Field-Site 1 during Periods 1 ( 21 months), 2 (24 months), 3 (24 months), and 4 (10 months) was recorded 97, 58, 52 , and 29 times, respectively.

\section{Quantity}

During the post-BMP periods, runoff occurred only when storms were larger and generally of longer durations and higher intensities than storms during the pre-BMP period (fig. 9). These changes were a result of terrace construction, which changed the runoff characteristics.

The change in runoff character was most evident in the change of the shape of runoff hydrographs for the different periods (fig. 10). During Period 1, before terracing, the hydrograph had numerous peaks of different sizes caused by varying rainfall intensities. Also, surface runoff from different parts of the field could be distinguished on the hydrograph; the most downgradient part of the field peaked first, followed by subsequent peaks from the upgradient cornfield. After terracing, water retention in the terraces and steady drainage through the pipe outlets resulted in a stepwise decline in stage as the terraces drained, regardless of precipitation intensity. During the summer of 1985, the initial hydrograph peak (fig. 10) was associated with runoff from the cornfield downgradient from the first terrace and initial outflow from the terraces. During Period 3, when the field downgradient from the first terrace was established in alfalfa, the initial runoff peaks generally did not occur.

Small runoff amounts drained through the pipe outlets for hours after the main bulk of the runoff discharged. This runoff, less than $0.01 \mathrm{ft}^{3} / \mathrm{s}$, was not measurable by the float/stage recorder and, therefore, was not accounted for in analysis of the data. Some immeasurable runoff also discharged during the pre-BMP monitoring but for shorter time periods. Comparison between total runoff before and after terracing may be slightly influenced by this factor.

For Periods 1, 2, 3, and 4, 9.8, 15, 13, and 3.9 percent, respectively, of the total precipitation discharged from the site as runoff (table 14). For the pre-BMP period, the runoff varied from 3 percent for the 9-month period in 1983 (January through September) to 13 percent for the 1984 water year. The rainfall distribution probably accounted for the low run off during 1983. Many small and moderate rainfalls occurred during the spring when the winter crop cover was high, and many small rainfalls occurred in the early summer on recently plowed, very loose soil. Annual variation was much less during Periods 2 and 3.

The change in discharge from Period 1 and the post-BMP periods was examined by regression analysis, covariate analysis, cluster analysis, and Mann-Whitney test.

Multiple-regression analyses of data from the pre-BMP period, used to determine explanatory variables, suggested that total runoff was primarily controlled by total precipitation and antecedent soil moisture (represented by the total precipitation for 30 days prior to runoff event). The maximum instantaneous discharge was controlled primarily by precipitation intensity and antecedent soil moisture. Regression analyses also suggested that crop cover on corn acreage reduced total runoff and discharges by intercepting rainfall and increasing evapotranspiration. Analysis of the pre-BMP data also showed that nearly all the rainfall ran off when the soil was frozen. If data from storms on frozen ground were excluded from the data base, results of regression analysis indicated that the total precipitation amount explained about 50 percent of the variability in total runoff (Lietman and others, 1996). Results from multiple-regression analysis of the post-BMP data also showed that the total runoff after terracing was controlled by the same factors-total precipitation and antecedent soil moisture-as was total runoff before terracing. However, after terracing, the maximum instantaneous storm discharges at the gage were controlled by flow restrictions through the pipe-outlet drainage system, in addition to climatological factors that affected mean and maximum discharge before terracing. 

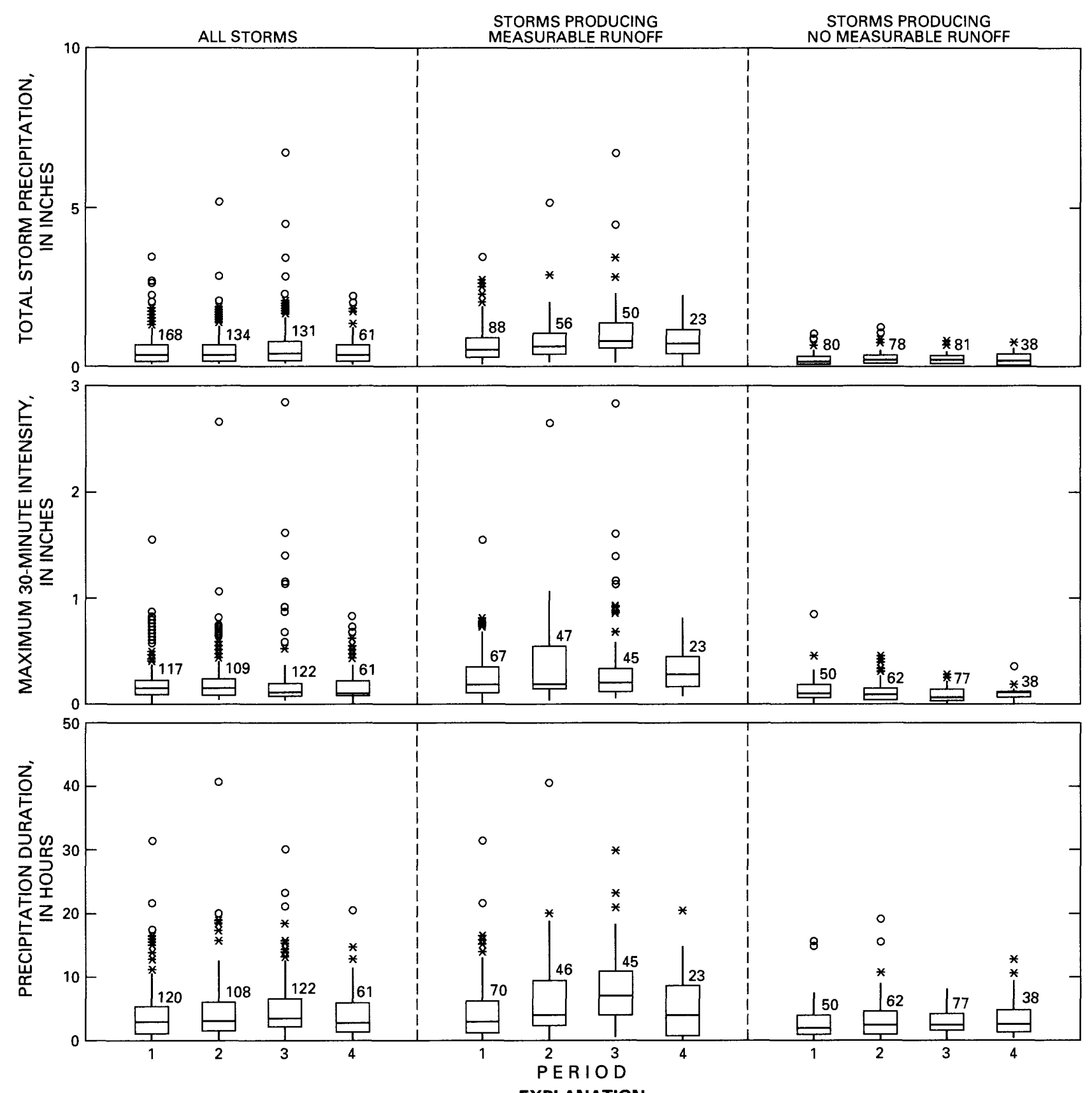

EXPLANATION

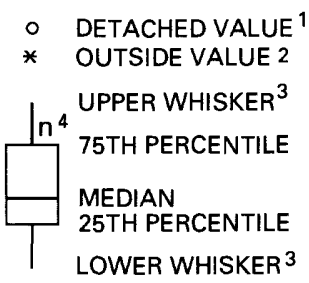

${ }^{1}$ A VALUE $>3$ TIMES THE INTERQUARTILE RANGE FROM THE BOX

2 A VALUE $>1.5$ AND $\leq 3$ TIMES THE INTERQUARTILE RANGE FROM THE BOX

${ }^{3}$ UPPER WHISKER IS THE LARGEST DATA POINT LESS THAN OR EQUAL TO THE UPPER QUARTILE PLUS 1.5 TIMES THE INTERQUARTILE RANGE. LOWER WHISKER IS THE SMALLEST DATA POINT GREATER THAN MINUS 1.5 TIMES THE INTEROUARTILE RANGE

${ }^{4} n=$ NUMBER OF OBSERVATIONS IN ANALYSIS

Figure 9.--Total storm precipitation, maximum 30-minute intensity within each storm, and storm duration for all storms, storms producing runoff, and storms that did not produce runoff during pre-best-management practice Period 1 (January 1983-September 1984) and post-best-management practice Periods 2 (October1984September 1986), 3 (October 1986-September 1988), and 4 (October 1988-July 1989) at Field-Site 1. 


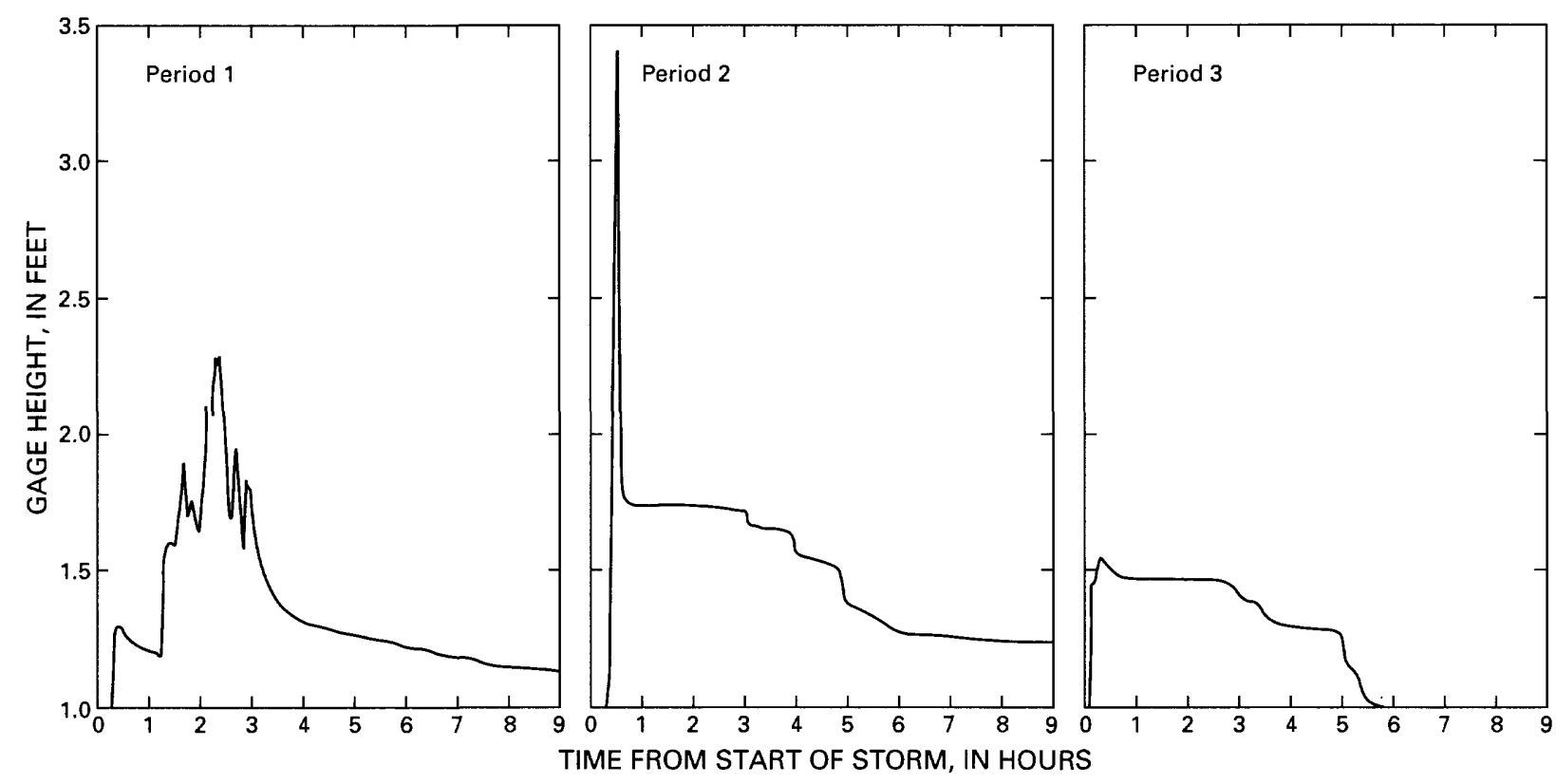

Figure 10.--Hydrographs of runoff at Field-Site 1 for a storm from Periods 1 (June 24, 1984), 2 (July 31, 1985), and 3 (July 26,1988$)$ with similar amounts of rainfall $(0.65-0.80$ inch) and similar soil conditions.

Table 14.-Discharge and percentage of precipitation as runoff from Field-Site 1

\begin{tabular}{lccc}
\hline Period $^{1}$ & $\begin{array}{c}\text { Water } \\
\text { year }\end{array}$ & $\begin{array}{c}\text { Total } \\
\text { discharge } \\
\text { (cubic feet } \\
\text { per acre) }\end{array}$ & $\begin{array}{c}\text { Percentage of } \\
\text { total precipitation } \\
\text { as runoff }\end{array}$ \\
\hline 1 & 21983 & 3,734 & 3.3 \\
1 & 1984 & 28,568 & 13.2 \\
2 & 1985 & 24,317 & 16.1 \\
2 & 1986 & 17,859 & 13.8 \\
3 & 1987 & 18,851 & 11.2 \\
3 & 1988 & 21,788 & 14.5 \\
4 & 31989 & 5,692 & 3.9 \\
\hline
\end{tabular}

${ }^{1}$ Period 1 (January 1983-September 1984) is the pre-best-management practice period; Periods 2 (October 1984-September 1986), 3 (October 1986-September 1988), and 4 (October 1988-July 1989) are the post-best-management practice period.

2 January through September 1983.

3 October 1988 through July 1989.

Analysis of covariance was used to determine significant differences in regression relations between Period 1 and the post-BMP periods for all storms that produced runoff except those occurring on frozen ground. The analysis results indicated that runoff as a function of total precipitation was not significantly different during Periods 3 and 4 than during Period 1 but was proportionally greater during Period 2 than during Period 1 (fig. 11 and table 15). However, visual examination of the graphical data showed that nearly all the data for Period 2 plotted within the variability of data for Period 1 (fig. 11). So, no conclusive evidence of differences between periods exist. Similar analysis by the use of multiple regression of the total discharge as a function of the log of total precipitation and the $\log$ of antecedent soil moisture yielded similar results. Figure 11 also shows that the small precipitation amounts (less than 0.2 in. during Period 2 and less than 0.4 in. during Periods 3 and 4 ) rarely produced runoff. 


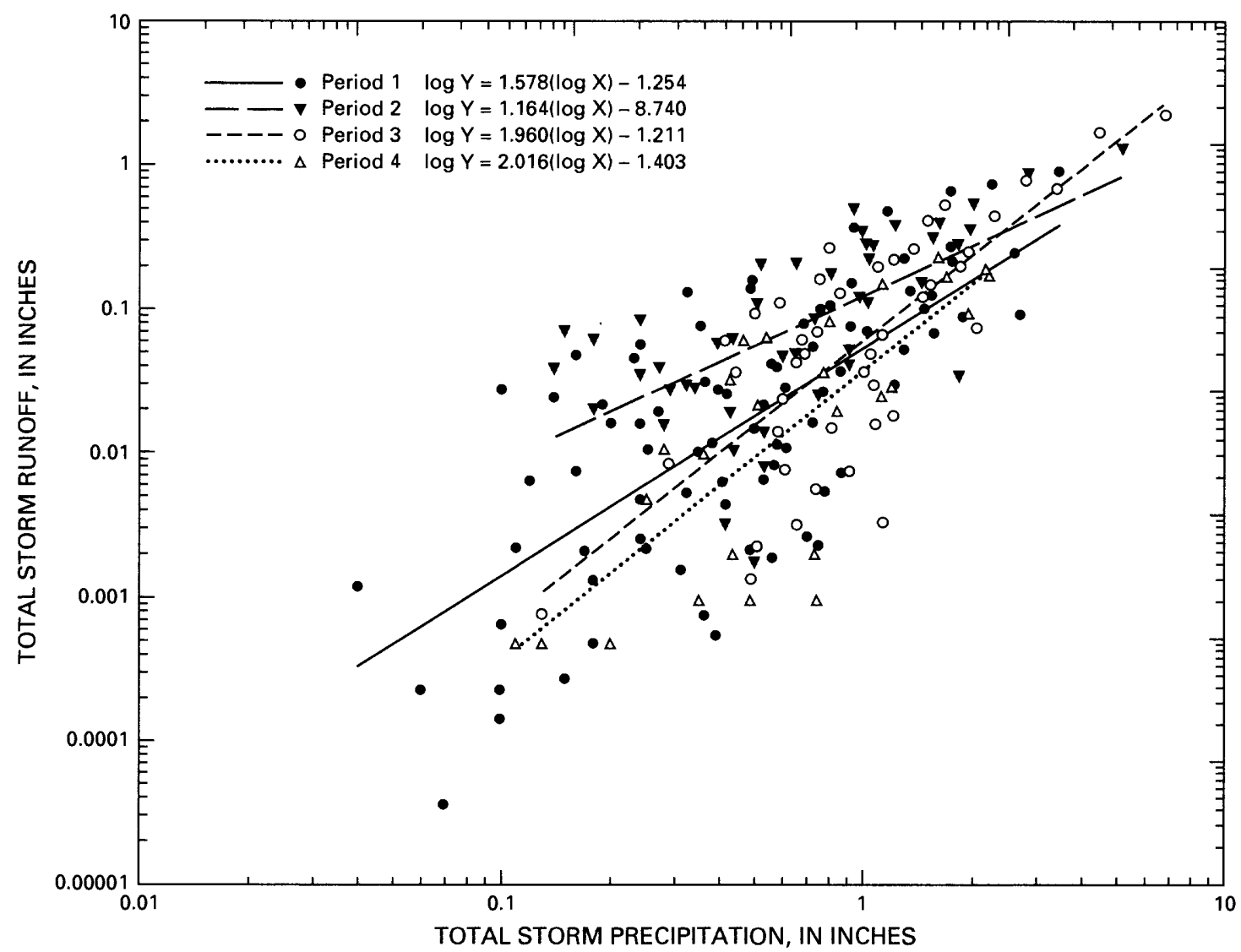

Figure 11.--Total storm runoff as a function of total precipitation at Field-Site 1 for all runoff events except runoff on frozen ground for pre-best-management practice Period 1 (January 1983 September 1984) and post-best-management practice Periods 2 (October 1984September 1986), 3 (October 1986-September 1988), and 4 (October 1988-July 1989). (Regression statistics are shown on table 15.)

Table 15.--Regression statistics for the log of total storm runoff at Field-Site 1, in inches, as a function of the log of storm precipitation, in inches, for all storms in each period

[Storms on frozen ground were excluded; <, less than]

\begin{tabular}{|c|c|c|c|c|c|c|c|c|c|}
\hline \multirow{3}{*}{ Period $^{1}$} & \multirow{3}{*}{$\begin{array}{l}\text { Degrees of } \\
\text { freedom }\end{array}$} & \multirow{3}{*}{$\begin{array}{l}\text { Coefficient of } \\
\text { the log of } \\
\text { total precipitation }\end{array}$} & \multirow{3}{*}{ t-statistic } & \multirow{3}{*}{ p-value } & \multirow{3}{*}{ Intercept } & \multirow{3}{*}{$\begin{array}{l}\text { Coefficient of } \\
\text { determination } \\
\left.\text { (adjusted } R^{2}\right)^{2}\end{array}$} & \multicolumn{3}{|c|}{ Standard error } \\
\hline & & & & & & & \multirow{2}{*}{$\begin{array}{l}\text { Log } \\
\text { units }\end{array}$} & \multicolumn{2}{|c|}{ Percent $^{3}$} \\
\hline & & & & & & & & Plus & Minus \\
\hline$\overline{1}$ & 84 & 1.578 & 8.47 & $<0.001$ & -1.254 & 0.46 & 0.70 & 401 & 80 \\
\hline 2 & 49 & 1.164 & 5.92 & $<.001$ & -8.740 & .41 & .47 & 195 & 66 \\
\hline 3 & 43 & 1.960 & 7.41 & $<.001$ & -1.211 & .46 & .54 & 247 & 71 \\
\hline
\end{tabular}

${ }^{1}$ Period 1 (January 1983-September 1984) is the pre-best-management practice period; Periods 2 (October 1984-September 1986), 3

(October 1986-September 1988), and 4 (October 1988-July 1989) are the post-best-management practice period.

${ }^{2}$ Coefficient of determination $\left(\mathbf{R}^{2}\right)$ adjusted for degrees of freedom.

${ }^{3}$ G.D. Tasker, U.S. Geological Survey, written commun., 1978. 
Because small storms rarely produced runoff during Period 3, regression and covariate analyses compared pre- and post-BMP storms that produced different amounts of runoff and precipitation. Therefore, cluster analysis (P-STAT, lnc., 1989) was used to separate the data into groups of similar type storms occurring during similar field conditions. A comparison of the similarly grouped, or clustered, data between periods is useful in verifying the conclusions on the basis of the results of covariate analyses.

Pre-BMP data analysis indicated that in addition to runoff being affected by total storm precipitation, antecedent soil-moisture conditions, and precipitation duration, runoff also was affected by precipitation intensity and crop cover (Lietman and others, 1996). These five characteristics were used to group all the storms occurring during the entire 79-month study period into eight clusters. Five clusters included all but seven of the storms. A characterization of the clusters is given in table 16, and data from five of the clusters are shown in figure 12. (For the cluster analysis, a factor from one to four was used to categorize crop cover: 1 is less than 15 percent, 2 is 15 to 49 percent, 3 is 50 to 85 percent, and 4 is greater than 85 percent.) Data from storms that produced runoff on frozen ground were eliminated from the data set, and runoff was set at zero when no runoff was measured for a storm.

Table 17 summarizes changes that were detected for four clusters by use of the Mann-Whitney test to determine differences in medians between Period 1 and the post-BMP periods for all storms and storms producing runoff. Cluster 3 was not included because there was an insufficient number of storms for comparison in Periods 2 and 3 . Clusters 2, 4, and 5 were not included because they represented too few storms for any period. The test results in table 17 show that for Clusters 1 and 7 (clusters containing small storms) fewer storms produced runoff during the post-BMP periods than during the pre-BMP period. For Cluster 1 storms, total storm discharge (on a per acre basis) decreased significantly from storms occurring in Period 1 to those occurring in Period 2, Period 3, or the entire post-BMP period. For Cluster 7 storms, total storm discharges decreased significantly from storms in Period 1 to those in Period 3 and the whole post-BMP period. Terracing changed the surface slopes, decreased runoff velocities, increased water-soil contact time, and increased surface storage. These factors promoted evaporation and soil wetting and delayed the onset of runoff. The influence of these factors was particularly apparent during small storms. Nearly all the storms in Clusters 6 and 8 , which produced about five times greater precipitation than storms in Clusters 1 and 7, produced runoff during all the periods. The total storm discharge for storms in Clusters 6 and 8 did not change from Period 1 to Period 3.

In summary, data analysis shows that after terracing and associated crop change occurred, storms that produced less than $0.4 \mathrm{in}$. of precipitation rarely produced runoff; therefore, in effect, terracing increased the threshold at which runoff occurs. The terrace BMP had no significant effect on runoff quantity during larger storms and no overall effect on runoff quantity.

\section{Quality}

Annual suspended-sediment and nutrient yields transported by runoff from Field-Site 1 are shown in table 18. Total yields for the 79-month study period averaged 2.7 (ton/acre)/yr for suspended sediment, 6.7 (lb/acre)/yr for nitrogen, and 3.4 (lb/acre)/yr for phosphorus. The 1984 annual suspended-sediment yield exceeded the erosion factor $\mathrm{T}$ of 4 (ton/acre)/yr recommended for the site by the U.S. Soil Conservation Service. ["The erosion factor $T$ is an estimate of the maximum average annual rate of soil erosion by wind or water that can occur without affecting crop productivity over a sustained period" (U.S. Department of Agriculture, 1985). The contribution of wind erosion is considered to be negligible for the site.] The suspendedsediment yield was substantially less than $T$ for all the years after terrace installation and after a year of stabilization (table 18). The annual yields of total nitrogen and phosphorus for the post-BMP period were within the range of yields for the pre-BMP period. However, during the pre-BMP period (Period 1), less than 10 percent of the annual yield of total nitrogen was nitrate plus nitrite, and over 90 percent was ammonia plus organic nitrogen; during post-BMP Periods 2 and 3,32 to 39 percent of the annual yield of total nitrogen was nitrate plus nitrite (table 18). For the 79-month study period, the nutrient yields in runoff represent about 2.5 and 5.0 percent of the nitrogen and phosphorus, respectively, applied to the site. 
Table 16.--General storm characteristics at Field-Site 1, by cluster, and percentage of total precipitation by period and cluster

[Storms on frozen ground were excluded from the data set prior to clustering.]

\begin{tabular}{|c|c|c|c|c|}
\hline Cluster & Characteristics & Period $^{1}$ & $\begin{array}{l}\text { Number of } \\
\text { storms }\end{array}$ & $\begin{array}{c}\text { Percentage of } \\
\text { total precipitation }\end{array}$ \\
\hline \multirow[t]{4}{*}{1} & \multirow[t]{4}{*}{ Summer showers on moist soil with crop cover. } & 1 & 31 & 11 \\
\hline & & 2 & 26 & 10 \\
\hline & & 3 & 21 & 10 \\
\hline & & 4 & 16 & 11 \\
\hline \multirow[t]{4}{*}{2} & \multirow{4}{*}{$\begin{array}{l}\text { Three large storms in December } 1983 \text {, } \\
\text { September } 1985 \text {, and June } 1987 \text {, with } \\
3.4 \text { to } 5.1 \text { inches of rain. }\end{array}$} & 1 & 1 & 3.8 \\
\hline & & 2 & 1 & 6.6 \\
\hline & & 3 & 1 & 3.9 \\
\hline & & 4 & 0 & 0 \\
\hline \multirow[t]{4}{*}{3} & \multirow{4}{*}{$\begin{array}{l}\text { Typical spring and fall all-day rains, generally } \\
\text { with } 0.2 \text { to } 0.6 \text { inch of precipitation on soil } \\
\text { with little crop coverage. }\end{array}$} & 1 & 22 & 9.4 \\
\hline & & 2 & 2 & .3 \\
\hline & & 3 & 2 & 1.7 \\
\hline & & 4 & 10 & 13 \\
\hline \multirow[t]{4}{*}{4} & \multirow{4}{*}{$\begin{array}{l}\text { One large September } 1987 \text { storm, with } 6.7 \text { inches } \\
\text { of rain. }\end{array}$} & 1 & 0 & 0 \\
\hline & & 2 & 0 & 0 \\
\hline & & 3 & 1 & 7.7 \\
\hline & & 4 & 0 & 0 \\
\hline \multirow[t]{4}{*}{5} & \multirow{4}{*}{$\begin{array}{l}\text { Three large summer storms, one in May } 1985 \\
\text { and two in July 1988, with } 2.8 \text { to } 4.5 \text { inches } \\
\text { of rain. }\end{array}$} & 1 & 0 & 0 \\
\hline & & 2 & 1 & 3.6 \\
\hline & & 3 & 2 & 8.3 \\
\hline & & 4 & 0 & 0 \\
\hline \multirow[t]{4}{*}{6} & \multirow{4}{*}{$\begin{array}{l}\text { Thunderstorms occurring predominantly in } \\
\text { the summer on soil with crop cover. }\end{array}$} & 1 & 18 & 18 \\
\hline & & 2 & 20 & 27 \\
\hline & & 3 & 10 & 14 \\
\hline & & 4 & 4 & 15 \\
\hline \multirow[t]{4}{*}{7} & \multirow{4}{*}{$\begin{array}{l}\text { Very small storms throughout the year on dry } \\
\text { soil, most storms occurring on soil with little } \\
\text { crop cover. }\end{array}$} & 1 & 67 & 22 \\
\hline & & 2 & 63 & 21 \\
\hline & & 3 & 73 & 24 \\
\hline & & 4 & 25 & 16 \\
\hline \multirow[t]{4}{*}{8} & \multirow{4}{*}{$\begin{array}{l}\text { Typical spring and fall all-day rains, generally } \\
\text { with } 0.8 \text { to } 1.6 \text { inches of precipitation on soil } \\
\text { with little crop cover. }\end{array}$} & 1 & 15 & 21 \\
\hline & & 2 & 11 & 7 \\
\hline & & 3 & 12 & 16 \\
\hline & & 4 & 26 & 9 \\
\hline
\end{tabular}

${ }^{1}$ Period 1 (January 1983-September 1984) is the pre-best-management practice period; Periods 2 (October 1984September 1986), 3 (October 1986-September 1988), and 4 (October 1988-July 1989) are the post-best-management practice period.

2 Total precipitation includes precipitation on frozen ground (table 6).

The distribution of total storm yields and mean storm concentrations for each constituent and each period is shown in figure 13. The boxplots summarize the concentrations and ranges of the data for the study. The extreme sediment yields found in Period 1 prior to terracing did not occur during the post-BMP periods; however, similar diminished extremes in the nutrient yields during the post-BMP periods did not occur. The extreme mean storm concentrations of suspended sediment, total ammonia plus organic nitrogen, total nitrogen, and total phosphorus decreased from Period 1 to the post-BMP periods, but extreme mean concentrations of total nitrate plus nitrite increased.

Pre-BMP data indicate that storm runoff on frozen ground responded differently than runoff from other storms (Lietman and others, 1996). Generally, mean concentrations and loads of suspended sediment in runoff were relatively low, and concentrations and load of total nitrogen were relatively high when the ground was 


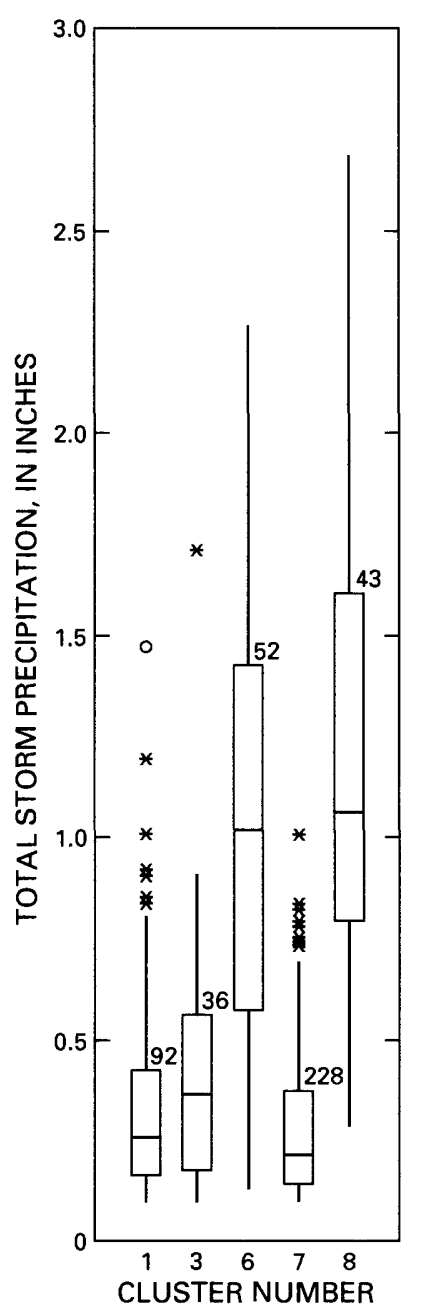

- DETACHED VALUE ${ }^{1}$

* outside VAlUe 2

\begin{tabular}{|l}
$\operatorname{nn}^{4} \begin{array}{l}\text { UPPER WHISKER } \\
\end{array}$ \\
$75 T H$ PERCENTILE \\
MEDIAN \\
25TH PERCENTILE \\
LOWER WHISKER
\end{tabular}
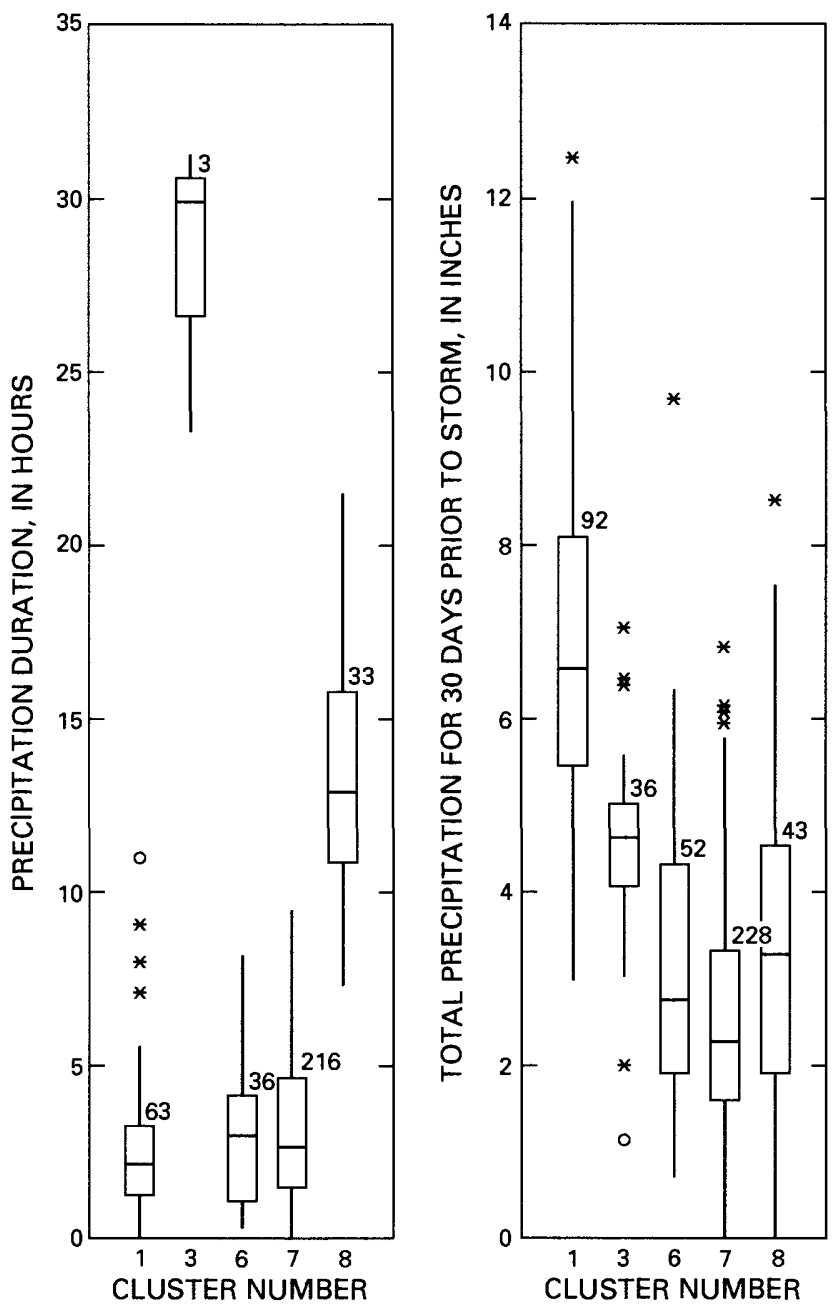

EXPLANATION

${ }^{1}$ A VALUE $>3$ TIMES THE INTEROUARTILE RANGE FROM THE BOX

${ }^{2}$ A VALUE $>1.5$ AND $\leq 3$ TIMES THE INTEROUARTILE RANGE FROM THE BOX

3 UPPER WHISKER IS THE LARGEST DATA POINT LESS THAN OR EQUAL TO THE UPPER QUARTILE PLUS 1.5 TIMES THE INTERQUARTILE RANGE. LOWER WHISKER IS THE SMALLEST DATA POINT GREATER THAN MINUS 1.5 TIMES THE INTERQUARTILE RANGE

${ }^{4} n=$ NUMBER OF OBSERVATIONS IN ANALYSIS

Figure 12.--Distribution of precipitation data at Field-Site 1 used to group similar type storms into clusters. (Clusters are described in table 16.)

frozen. However, a shallow surface thaw probably increased the availability of suspended sediment during one storm on frozen ground compared to runoff from all other storms (Lietman and others, 1996). Therefore, all storms except those that produced runoff on frozen ground were used for data analysis.

Graphical and regression analyses of total storm runoff were used to investigate the relation between yields and total storm runoff and differences in the relation between pre-BMP and post-BMP periods over the range of runoff quantities (figs. 14 through 18 and table 19). Suspended-sediment yields as a function of runoff were lower during Period 3 after terraces stabilized for 2 years and after the field downslope from the first terrace was stabilized with alfalfa (fig. 14) than during Period 1. This result was expected and was the primary purpose for installing the terraces at the site and establishing the lower alfalfa field. 


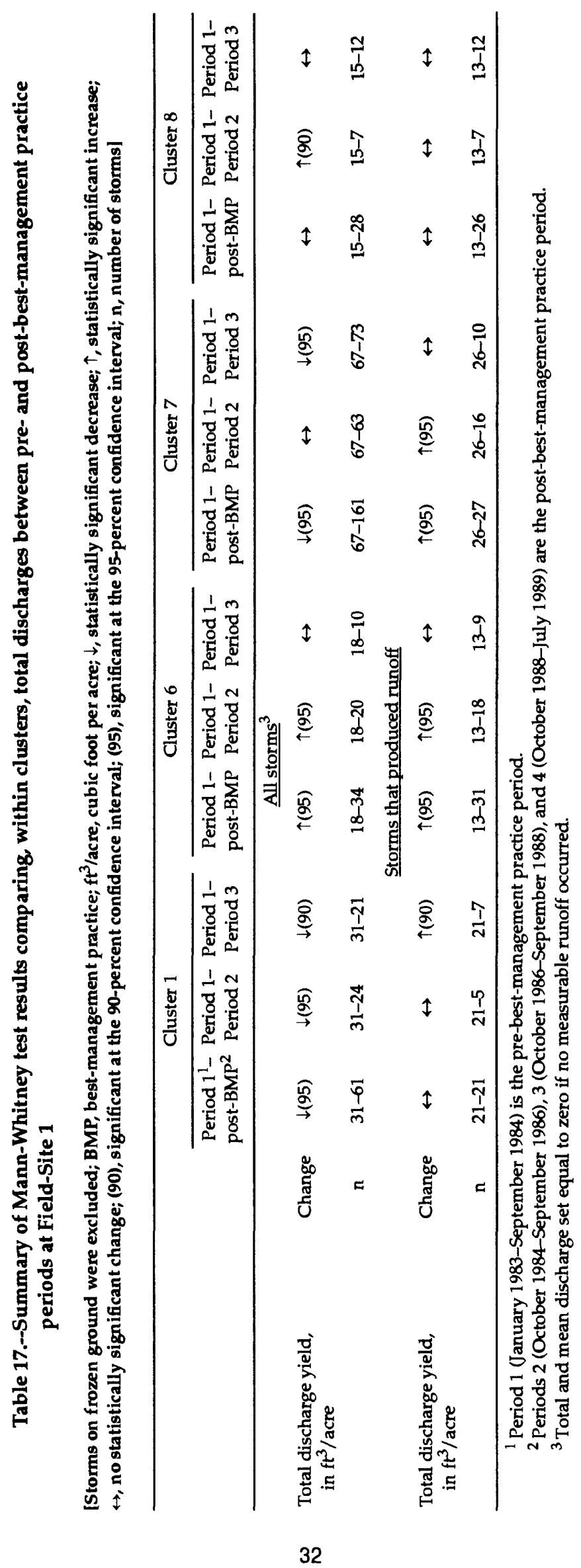


Table 18.--Suspended-sediment and nutrient yields in runoff from Field-Site 1

[ton/acre, ton per acre; lb/acre, pound per acre; $N$, nitrogen]

\begin{tabular}{|c|c|c|c|c|c|c|}
\hline Period ${ }^{l}$ & $\begin{array}{l}\text { Water } \\
\text { year }\end{array}$ & $\begin{array}{l}\text { Suspended- } \\
\text { sediment } \\
\text { yield } \\
\text { (ton/acre) }\end{array}$ & $\begin{array}{c}\text { Total } \\
\text { nitrogen } \\
\text { yield } \\
\text { (lb/acre) }\end{array}$ & $\begin{array}{c}\text { Ammonia } \\
\text { plus organic } \\
\text { nitrogen yield } \\
\text { (percentage } \\
\text { of total } \mathrm{N} \text { ) }\end{array}$ & $\begin{array}{c}\text { Nitrate } \\
\text { plus nitrite } \\
\text { nitrogen yield } \\
\text { (percentage } \\
\text { of total } \mathbf{N} \text { ) }\end{array}$ & $\begin{array}{c}\text { Total } \\
\text { phosphorus } \\
\text { yield } \\
\text { (lb/acre) }\end{array}$ \\
\hline 1 & ${ }^{2} 1983$ & 0.70 & 1.8 & 91 & 9 & 1.0 \\
\hline 1 & 1984 & 11 & 12 & 92 & 8 & 7.0 \\
\hline 2 & 1985 & 3.4 & 8.0 & 68 & 32 & 3.1 \\
\hline 2 & 1986 & .83 & 6.3 & 68 & 32 & 2.9 \\
\hline 3 & 1987 & .54 & 4.6 & 61 & 39 & 4.0 \\
\hline 3 & 1988 & 1.0 & 9.3 & 64 & 36 & 3.8 \\
\hline 4 & ${ }^{3} 1989$ & ${ }^{4} .28$ & 3.4 & 78 & 22 & 1.3 \\
\hline
\end{tabular}

${ }^{1}$ Period 1 (January 1983-September 1984) is the pre-best-management practice period; Periods 2 (October 1984September 1986), 3 (October 1986-September 1988), and 4 (October 1988-July 1989) are the post-best-management practice period.

${ }_{2}$ January through September 1983.

3 October 1988 through July 1989.

${ }^{4}$ The regressions in table 4 used to estimate yields of unsampled storms were used, although the statistics indicated that the regressions were not statistically significant.

Analysis of covariance indicated that runoff carried proportionally less sediment during Periods 2 and 4 than during Period 1. Analysis of covariance also showed statistically significant changes in the intercept and slope of the regression lines from Period 1 to Period 3. Graphical analysis shows that runoff produced from moderate storms carried about the same amount of sediment relative to runoff quantity during Period 1 and Period 3, but runoff produced by large storms carried much less sediment relative to runoff quantity during Period 3 than during Period 1 (fig. 15 and table 19).

Total yields of nitrate plus nitrite as a function of total storm runoff for each post-BMP period were different than the yields for Period 1 (fig. 15 and table 19). Analysis of covariance indicated that proportionally more nitrate was carried in runoff during each of the post-BMP periods than during Period 1.

The only other statistically significant change detected between periods in nitrogen or phosphorus yields as a function of runoff (fig. 17, 18, and 19) was higher yields of ammonia plus organic nitrogen (fig. 16) and of total nitrogen (fig. 17) relative to total storm runoff between Period 1 and Period 4 . However, Period 4 represented a smaller time period (10 months) with fewer storms than Period 1 (21 months). Thus, interpretation of the data was limited.

Mean storm concentration and yield data for suspended sediment and nutrients were compared within the clusters as described earlier in this section to improve an understanding of the effects of terracing on runoff quality (fig. 12 and table 16).

For storms in clusters 6,7 , and 8 , mean suspended-sediment concentrations decreased from Period 1 to Period 3 and from Period 1 to the entire post-BMP period (tables 20 and 21). The terraces reduced runoff energy and, thus, the ability to transport sediment. Also, pooling in terraces allowed time for deposition of suspended material before the runoff discharged through the pipe outlet. For storms in Cluster 1, which contained the smallest storms, no significant change was detected in suspended-sediment concentrations from Period 1 to Period 3 by use of the Mann-Whitney test. Yields of suspended sediment per unit of discharge within Cluster 1 were generally larger during Period 1 than during Period 3 . The distribution of the data may bias the statistical analysis within Cluster 1 because no runoff was produced by the small storms in this cluster during the post-BMP periods. 

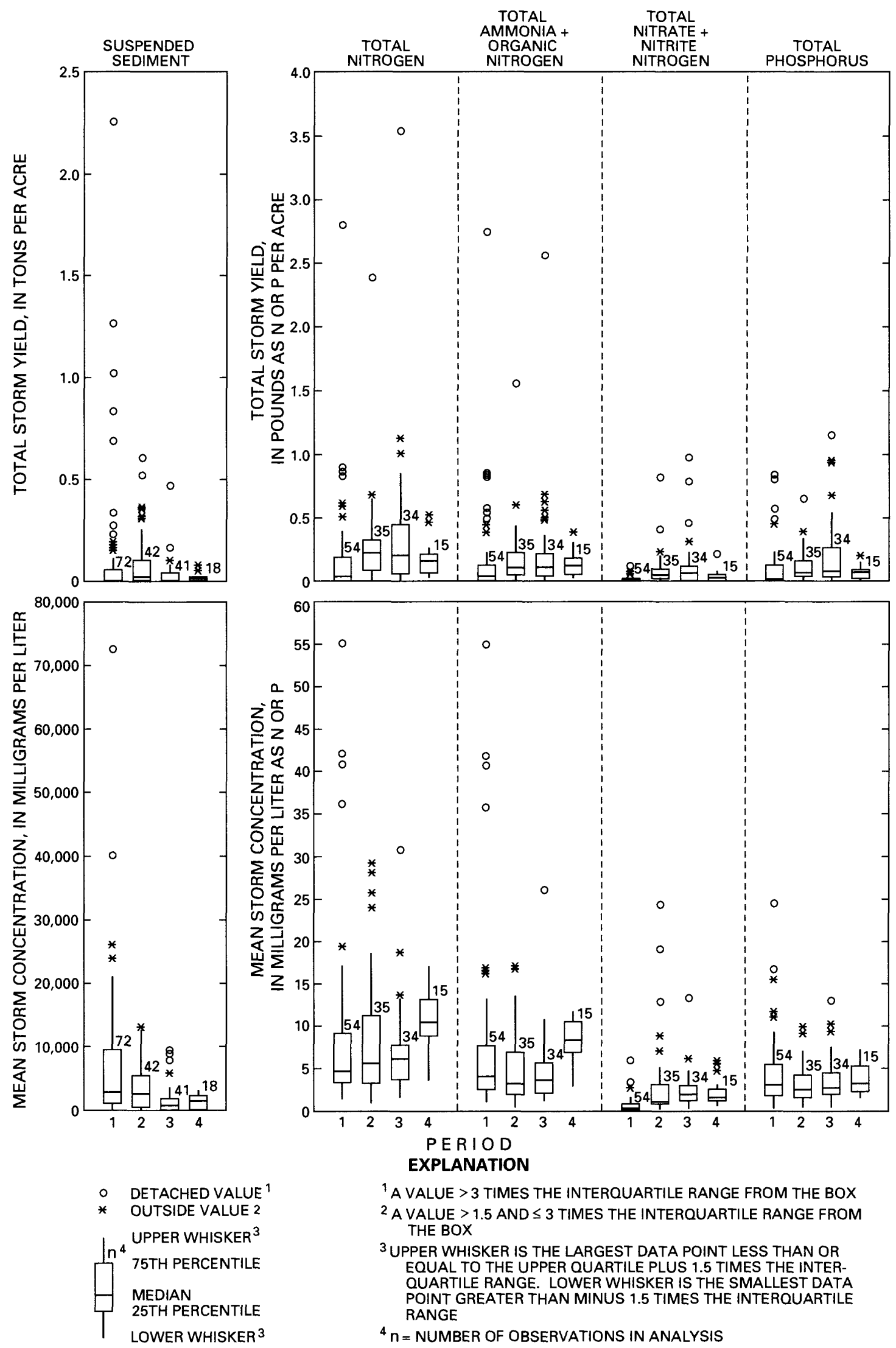

${ }^{1}$ A VALUE $>3$ TIMES THE INTEROUARTILE RANGE FROM THE BOX

2 A VALUE $>1.5$ AND $\leq 3$ TIMES THE INTEROUARTILE RANGE FROM THE BOX

${ }^{3}$ UPPER WHISKER IS THE LARGEST DATA POINT LESS THAN OR EQUAL TO THE UPPER QUARTILE PLUS 1.5 TIMES THE INTERQUARTILE RANGE. LOWER WHISKER IS THE SMALLEST DATA POINT GREATER THAN MINUS 1.5 TIMES THE INTERQUARTILE RANGE

${ }^{4} n=$ NUMBER OF OBSERVATIONS IN ANALYSIS

Figure 13.--Distribution of suspended-sediment and nutrient yields and mean storm concentrations in runoff from Field-Site 1 for pre-best-management practice Period 1 (January 1983September 1984) and post-best-management practice Periods 2 (October 1984September 1986), 3 (October 1986-September 1988), and 4 (October 1988-July 1989). 


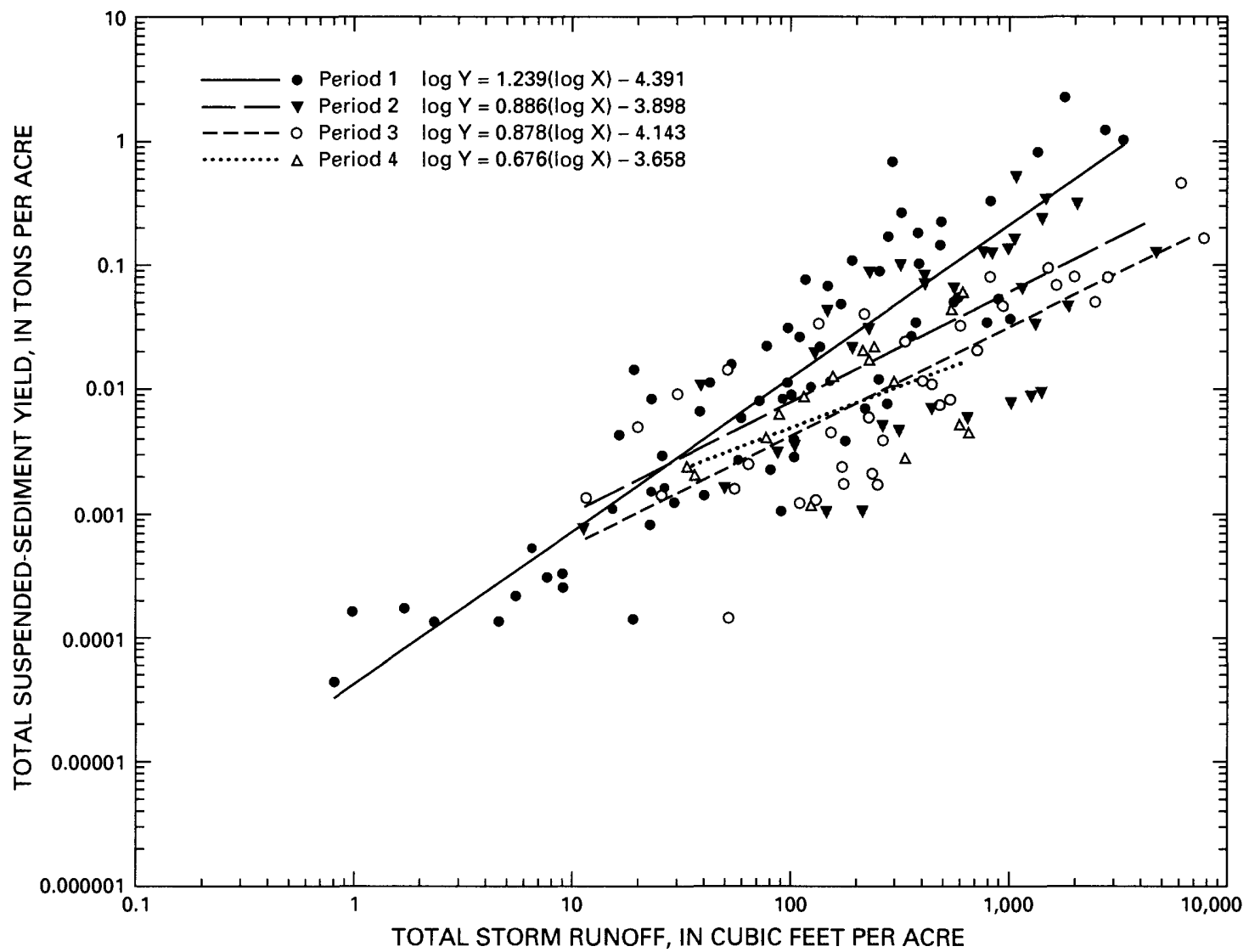

Figure 14.--Total suspended-sediment yield in runoff as a function of total storm runoff for all runoff events at Field-Site 1 except runoff on frozen ground for pre-best-management practice Period 1 (January 1983-September 1984) and post-best-management practice Periods 2 (October 1984-September 1986), 3 (October 1986-September 1988), and 4 (October 1988-July 1989). (Regression statistics are shown on table 19.)

A decrease in mean storm concentrations of total phosphorus was detected (90-percent confidence level) for storms in Cluster 6 from Period 1 to Period 2, but no change was detected between Period 1 and Period 3. Because phosphorus sorbs tightly to soil particles, the change in phosphorus concentrations may have resulted from a change in suspended sediment transported by these storms. Storms in Cluster 6 produced the largest suspended-sediment concentrations during Period 1 (table 21), and the largest decreases in suspended-sediment concentrations were noted between Period 1 and Period 2 and Period 1 and Period 3 (median concentrations decreased by 4,200 and $7,200 \mathrm{mg} / \mathrm{L}$, respectively).

Concentrations of total phosphorus did not decrease proportionately with suspended-sediment concentrations throughout most of the storm groupings (table 21). It is believed, from observation and other limited particle-size data analysis, that most of the fine-sediment particles (less than $0.62 \mu \mathrm{m}$ in diameter) continued to be discharged from the site after terracing, and that most of the phosphorus was transported with fine-grained particles. Particle-size analysis of instantaneous suspended-sediment samples showed that a significantly larger percentage of the sediment in runoff was silt and clay (sediment finer than $0.62 \mu \mathrm{m}$ in diameter) after terracing than before terracing (fig. 19). A median of 96 percent of the sediment in runoff from samples collected during the 1986- 88 water years was silt and clay, whereas a median of 86 percent of the sediment in runoff from samples collected during the 1983-84 water years was silt and clay. Limited phosphorus-concentration data on 


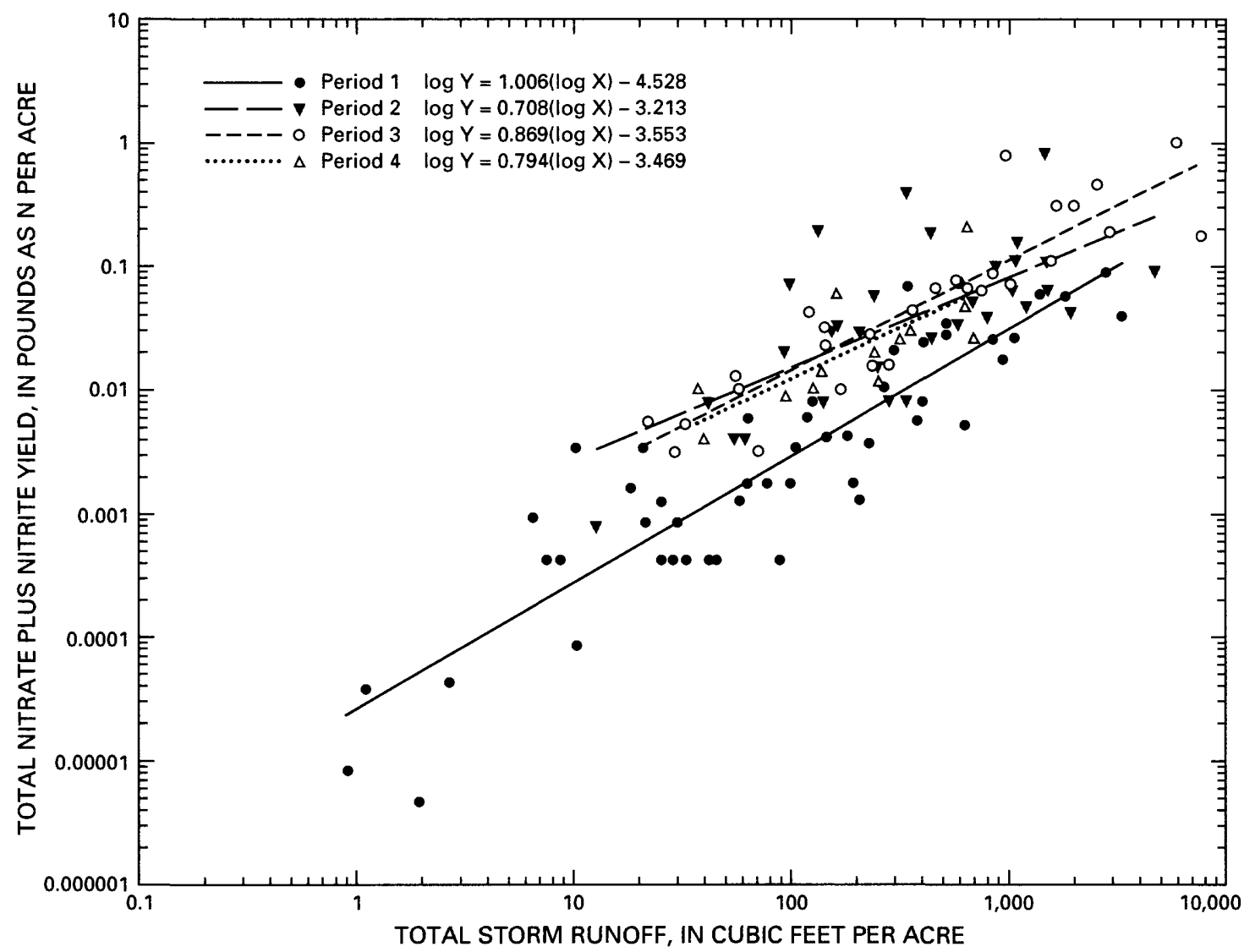

Figure 15.--Total nitrate plus nitrite yield in runoff as a function of total storm runoff for all runoff events at Field-Site 1 except runoff on frozen ground for pre-best-management practice Period 1 (January 1983-September 1984) and post-best-management practice Periods 2 (October 1984-September 1986), 3 (October 1986-September 1988), and 4 (October 1988July 1989). (Regression statistics are shown on table 19.)

instantaneous-runoff samples shows that a median of 90 percent of the total phosphorus in runoff was suspended before terracing and 82 percent after terracing (fig. 20). By use of the Mann-Whitney test, no change was detected in the concentrations of total and suspended phosphorus from the pre-BMP to post-BMP periods, but the dissolved phosphorus increased significantly. The small number of samples limits any conclusions from the data analysis, but small dissolved-phosphorus increases possibly offset any decrease in suspendedphosphorus concentrations that may have occurred.

The mean storm concentrations of nitrate plus nitrite increased significantly (changes were from twofold to ninefold) from the pre-BMP to each of the post-BMP periods (tables 20 and 21) within each cluster, except for runoff events in Cluster 7 for Period 2. Therefore, regardless of the storm type, nitrate transport by runoff increased over time. During storms after terrace construction, when no runoff was produced, overall soil moisture may have increased, allowing increased nitrification and, therefore, increased nitrate amounts that were available to transport by runoff. During all storms after terracing, the soil-wetting area probably increased as a result of an increase in sheet runoff and a reduction in gully runoff. Thus, the increased contact time and the possibly increased contact area of the runoff water with the nutrient-rich soils allowed for an increase in the conversion to and dissolution of nitrate. During many storms, runoff pooled in the terraces, a process that also increased nitrification and increased solution of nitrate. 


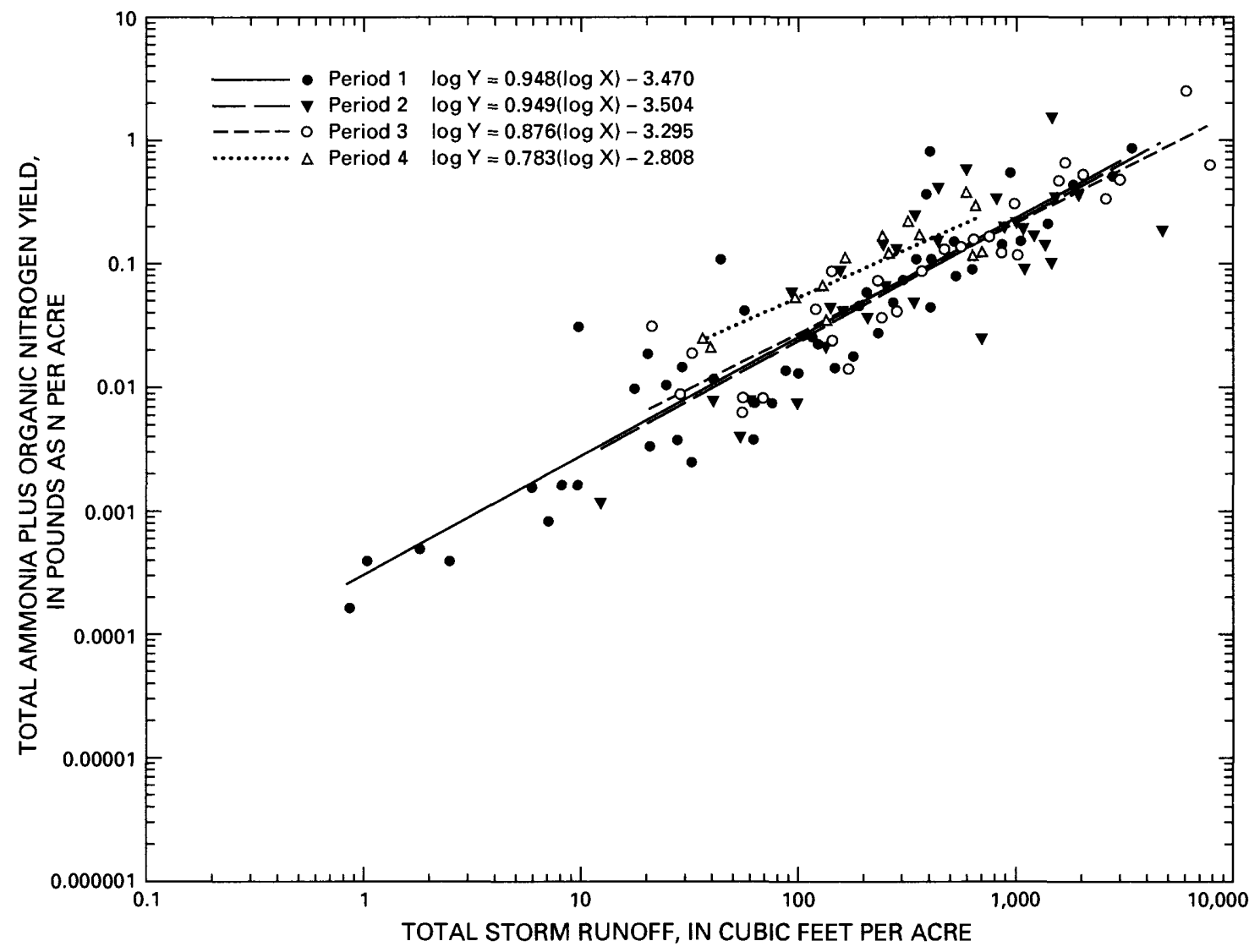

Figure 16.--Total ammonia plus organic nitrogen yield in runoff as a function of total storm runoff for all runoff events at Field-Site 1 except runoff on frozen ground for pre-best-management practice Period 1 (January 1983-September 1984) and post-best-management practice Periods 2 (October 1984-September 1986), 3 (October 1986-September 1988), and 4 (October 1988-July 1989). (Regression statistics are shown on table 19.)

The median storm concentrations of total nitrogen in runoff during Period 3 were greater than or equal to the total nitrogen concentrations during Period 1 for each cluster. However, a significant increase in mean concentrations of total nitrogen in runoff was only detected from Period 1 to Period 3 for storms in Clusters 1 and 8 . The data distribution within Cluster 1 may bias this statistical analysis, as discussed previously. The increase in total nitrogen for Cluster 8 storms was primarily because of the large increases in nitrate concentrations.

No changes within clusters were found in mean storm concentrations of ammonia plus organic nitrogen in runoff between Periods 1 and 3. The only significant changes in these concentrations in runoff occurred in the Cluster 1 storms between Period 1 and Period 2 and between Period 1 and the entire post-BMP period. The mean storm concentrations of ammonia plus organic nitrogen in runoff were much more variable than the mean storm concentrations of nitrate plus nitrite in runoff. Concentrations of total nitrogen, which are the sum of ammonia plus organic nitrogen and nitrate plus nitrite, also were more variable than concentrations of nitrate plus nitrite. Therefore, significant changes could be detected in the concentrations of nitrate plus nitrite without detecting correspondingly significant changes in concentrations of total nitrogen. Figure 21 shows the change in monthly mean concentrations of nitrate plus nitrite in runoff for storms that were sampled after the terrace 


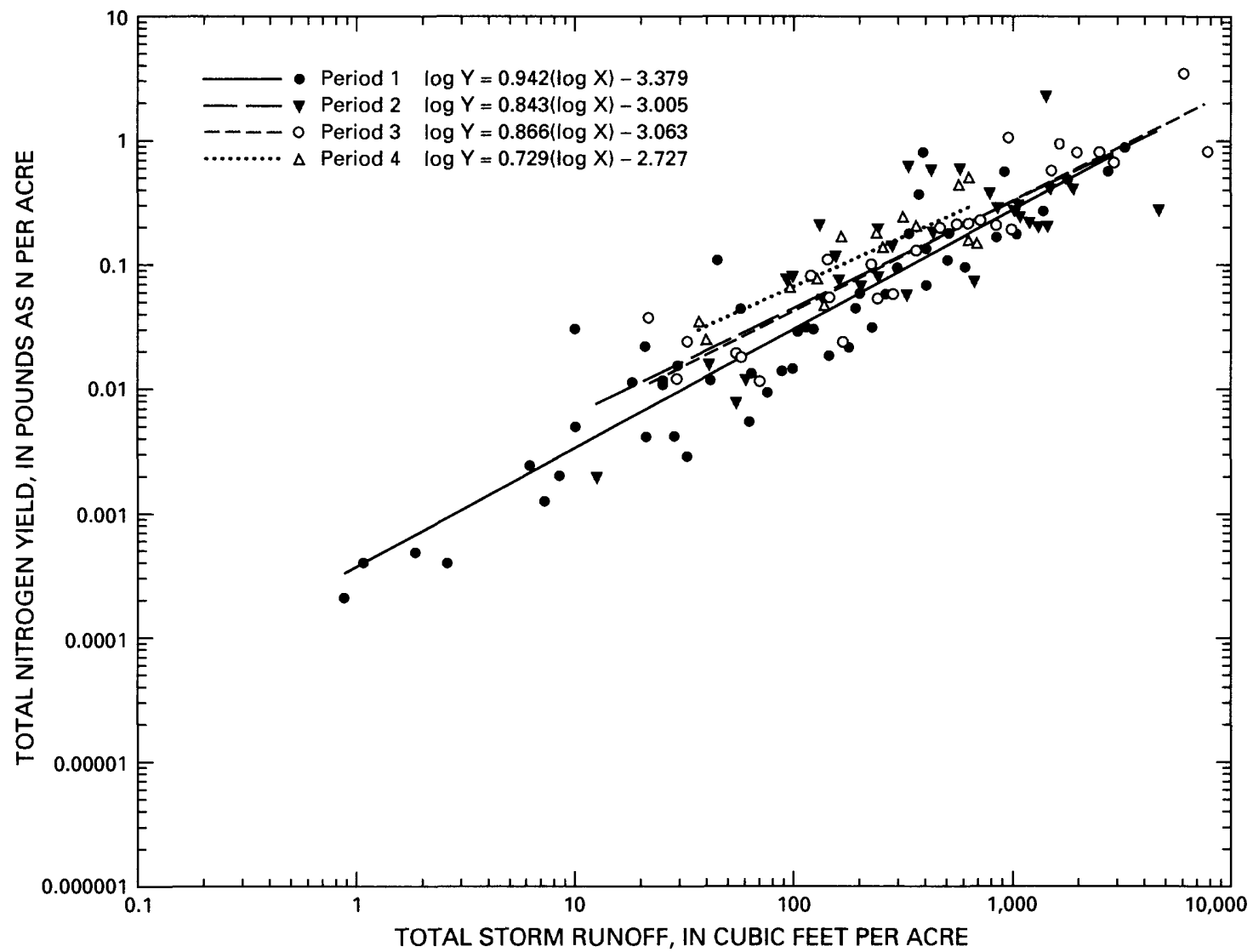

Figure 17.--Total nitrogen yield in runoff as a function of total storm runoff for all runoff events at Field-Site 1 except runoff on frozen ground for pre-best-management practice Period 1 (January 1983-September 1984) and post-best-management practice Periods 2 (October 1984-September 1986), 3 (October 1986-September 1988), and 4 (October 1988-July 1989). (Regression statistics are shown on table 19.)

installation in October 1984. The monthly mean storm concentrations of total nitrogen in runoff generally appear to respond to nitrogen applications to the site. However, because of the varying lag times between applications and runoff and lack of nitrogen data for every runoff event, no statistical relation between land-surface applications and monthly mean storm concentrations of total nitrogen in runoff could be established.

During the analysis of pre-BMP data, an attempt to relate the principal agricultural activity and precipitation factors to nutrients in runoff was made by the use of graphical and multiple regression analyses, excluding runoff events that occurred when the ground was frozen and immediately after plowing. The analyses indicated that a general increase in mean concentrations of total nitrogen occurred with increased nitrogen applications in the 15,30 , or 45 days before a runoff event (30 days produced the best correlations) (Lietman and others, 1996). When precipitation factors were considered in the data analyses, including total inches of precipitation, hours of precipitation duration, antecedent soil-moisture conditions, and precipitation intensity, only the addition of precipitation duration was statistically significant in the regression. The analysis indicated that nitrogen concentration decreases with increasing duration, implying that concentrations are diluted by continuing rainfall. A baseline nitrogen concentration in runoff which, by examination of the runoff data, appeared to have occurred regardless of fertilizer use, indicated that the mean nitrogen concentration during a runoff event is probably 


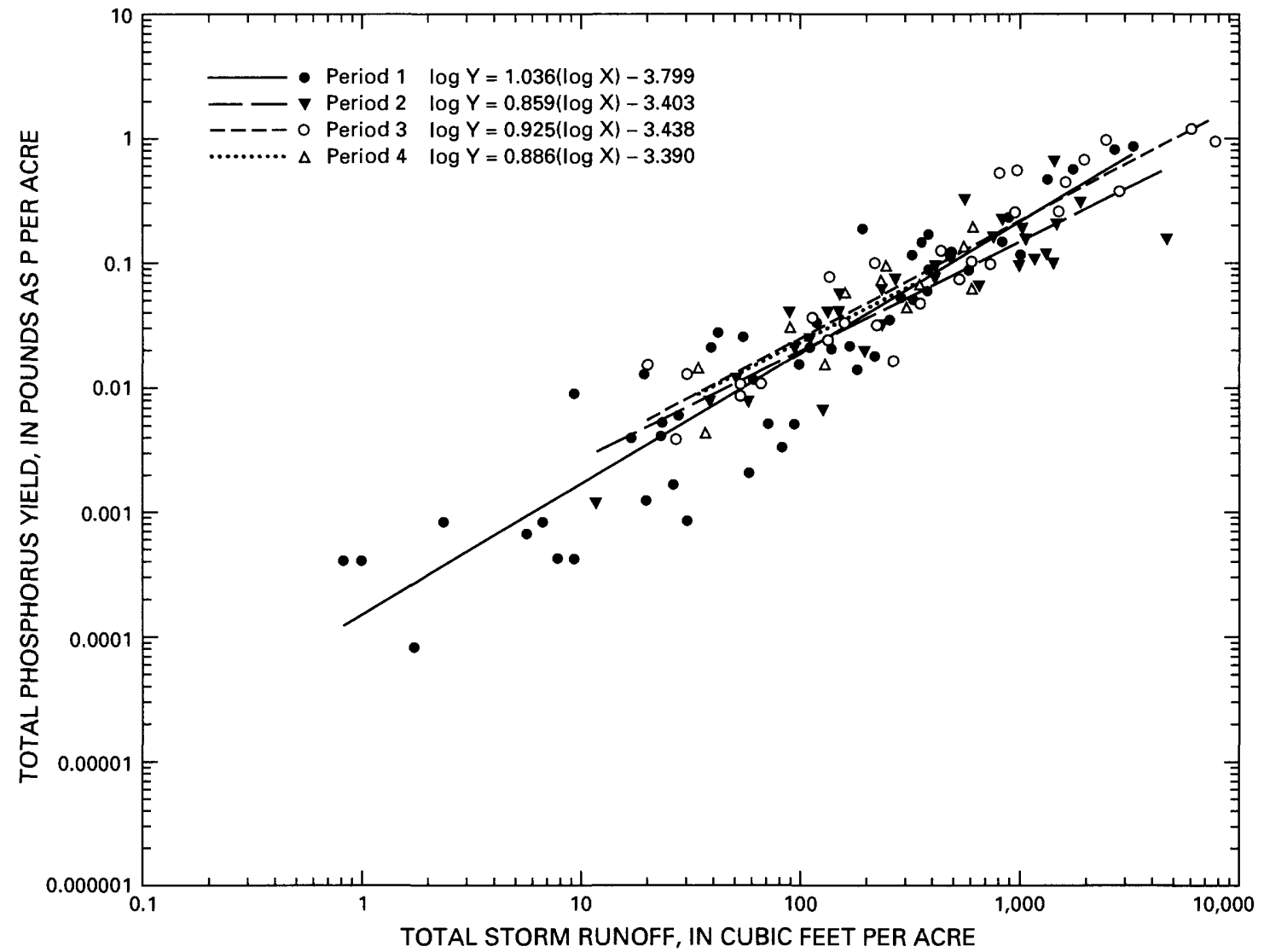

Figure 18.--Total phosphorus yield in runoff as a function of total storm runoff for all runoff events at Field-Site 1 except runoff on frozen ground for pre-best-management practice Period 1 (January 1983-September 1984) and post-best-management practice Periods 2 (October 1984-September 1986), 3 (October 1986-September 1988), and 4 (October 1988July 1989). (Regression statistics are shown on table19.)

affected by the amount of nitrogen bound to the soil. Total nitrogen accounts for an average of about 0.25 percent (by weight) of the soil, on the basis of soil analysis of the top 2 in. This same type of data analysis was performed to attempt to relate phosphorus concentrations in runoff to phosphorus application but did not result in any significant relations between variables.

Although nutrient applications were not substantially reduced during the post-BMP period, nutrient applications were generally made a little less frequently. Because many storms during the post-BMP period occurred when no field applications of nutrients had been made within 30 days prior to a runoff event, the same data analysis was not possible for the post-BMP period.

Data presented on figure 21, showing the mean monthly concentration of total nitrogen for sampled storms, indicate that mean concentrations of total nitrogen generally reflect nitrogen applications to the site. Additionally, figure 21 shows the increase in mean storm nitrate concentrations in runoff after terrace construction. A quantitative analysis was not possible to compare the pre- and post-BMP periods because a strong statistical correlation does not exist between the nitrogen application and runoff nitrogenconcentration data. 
Although atrazine was the predominant herbicide detected in runoff at Field-Site 1, metolachlor and cyanazine were also detected. The maximum concentrations of atrazine, up to $140 \mu \mathrm{g} / \mathrm{L}$, in runoff were measured during the first storms after atrazine applications. Concentrations of atrazine in runoff decreased from the peak concentrations in May through the summer (fig. 22). Concentrations of atrazine in the top 2 in. of soil declined rapidly during the same time period (fig. 8). Metolachlor was also detected in runoff during 1984-86, and cyanazine was detected in runoff in 1987 after they were applied to the site. Each year, the maximum concentrations of metolachlor and cyanazine (up to 137 and $46 \mu \mathrm{g} / \mathrm{L}$, respectively) were measured during the first storm sampled after application in May, and concentrations decreased in subsequent storms to near-reporting levels by August. Changes in herbicide concentration in runoff samples from the pre- to the post-BMP period were not observed.

Table 19.--Regression statistics for suspended-sediment and total nutrient yields as a function of total storm runoff for all runoff events occurring during each period at Field-Site 1

[Runoff on frozen ground was excluded; suspended-sediment yield is in tons per acre; nutrient yields are in pounds per acre of nitrogen or phosphorus; total runoff is in cubic feet per acre; all variables are log-transformed; <, less than]

\begin{tabular}{|c|c|c|c|c|c|c|c|c|c|c|}
\hline \multirow{3}{*}{ Period $^{1}$} & \multirow{3}{*}{$\begin{array}{l}\text { Dependent } \\
\text { variable }\end{array}$} & \multirow{3}{*}{$\begin{array}{l}\text { Degrees } \\
\text { of freedom }\end{array}$} & \multirow{3}{*}{$\begin{array}{c}\begin{array}{c}\text { Regression } \\
\text { coefficient }\end{array} \\
\text { Log of } \\
\text { total runoff }\end{array}$} & \multirow{3}{*}{ t-statistic } & \multirow{3}{*}{$\mathrm{p}$-value } & \multirow{3}{*}{ Intercept } & \multirow{3}{*}{$\begin{array}{l}\text { Coefficient of } \\
\text { determination } \\
\text { (adjusted R2) }^{2} \text { - }\end{array}$} & \multicolumn{3}{|c|}{$\begin{array}{l}\text { Standard } \\
\text { error }\end{array}$} \\
\hline & & & & & & & & \multirow[b]{2}{*}{$\begin{array}{l}\text { Log } \\
\text { units }\end{array}$} & \multicolumn{2}{|c|}{ Percent } \\
\hline & & & & & & & & & Plus & Minus $^{3}$ \\
\hline$\overline{1}$ & Suspended sediment & 65 & 1.239 & 15.47 & $<0.001$ & -4.391 & 0.82 & 0.495 & 213 & 68 \\
\hline 2 & Suspended sediment & 37 & .886 & 5.27 & $<.001$ & -3.898 & .42 & .573 & 274 & 73 \\
\hline 3 & Suspended sediment & 34 & .878 & 7.13 & $<.001$ & -4.143 & .60 & .491 & 210 & 68 \\
\hline 4 & Suspended sediment & 16 & .676 & 2.66 & .018 & -3.658 & .28 & .406 & 155 & 61 \\
\hline 1 & Total nitrogen & 49 & .942 & 16.85 & $<.001$ & -3.379 & .85 & .341 & 119 & 54 \\
\hline 2 & Total nitrogen & 31 & .843 & 7.33 & $<.001$ & -3.005 & .63 & .370 & 134 & 57 \\
\hline 3 & Total nitrogen & 27 & .866 & 12.21 & $<.001$ & -3.063 & .85 & .259 & 82 & 45 \\
\hline 4 & Total nitrogen & 13 & .792 & 6.24 & $<.001$ & -2.727 & .74 & .194 & 56 & 36 \\
\hline 1 & $\begin{array}{c}\text { Total ammonia plus } \\
\text { organic nitrogen }\end{array}$ & 49 & .948 & 15.77 & $<.001$ & -3.470 & .83 & .367 & 133 & 57 \\
\hline 2 & $\begin{array}{c}\text { Total ammonia plus } \\
\text { organic nitrogen }\end{array}$ & 31 & .949 & 7.66 & $<.001$ & -3.504 & .65 & .398 & 150 & 60 \\
\hline 3 & $\begin{array}{c}\text { Total ammonia plus } \\
\text { organic nitrogen }\end{array}$ & 27 & .876 & 11.60 & $<.001$ & -3.295 & .83 & .276 & 89 & 47 \\
\hline 4 & $\begin{array}{l}\text { Total ammonia plus } \\
\text { organic nitrogen }\end{array}$ & 13 & .783 & 6.08 & $<.001$ & -2.808 & .73 & .196 & 57 & 36 \\
\hline 1 & Total nitrate plus nitrite & 49 & 1.006 & 14.23 & $<.001$ & -4.528 & .80 & .431 & 170 & 63 \\
\hline 2 & Total nitrate plus nitrite & 31 & .708 & 4.91 & $<.001$ & -3.213 & .43 & .464 & 191 & 66 \\
\hline 3 & Total nitrate plus nitrite & 27 & .869 & 10.59 & $<.001$ & -3.553 & .80 & .300 & 100 & 50 \\
\hline 4 & Total nitrate plus nitrite & 13 & .794 & 4.17 & .001 & -3.469 & .56 & .290 & 95 & 49 \\
\hline 1 & Total phosphorus & 49 & 1.036 & 16.65 & $<.001$ & -3.799 & .85 & .379 & 139 & 58 \\
\hline 2 & Total phosphorus & 31 & .859 & 10.32 & $<.001$ & -3.403 & .77 & .267 & 85 & 46 \\
\hline 3 & Total phosphorus & 27 & .925 & 12.90 & $<.001$ & -3.438 & .86 & .262 & 83 & 45 \\
\hline 4 & Total phosphorus & 13 & .886 & 6.25 & $<.001$ & -3.390 & .74 & .216 & 64 & 39 \\
\hline
\end{tabular}

${ }^{1}$ Period 1 (January 1983-September 1984) is the pre-best-management practice period; Periods 2 (October 1984-September 1986),

3 (October 1986-September 1988), and 4 (October 1988-July 1989) are the post-best-management practice period.

${ }^{2} R^{2}$ adjusted for degrees of freedom to allow more valid comparison between seasons.

${ }^{3}$ G.D. Tasker, U.S. Geological Survey, written commun., 1978. 


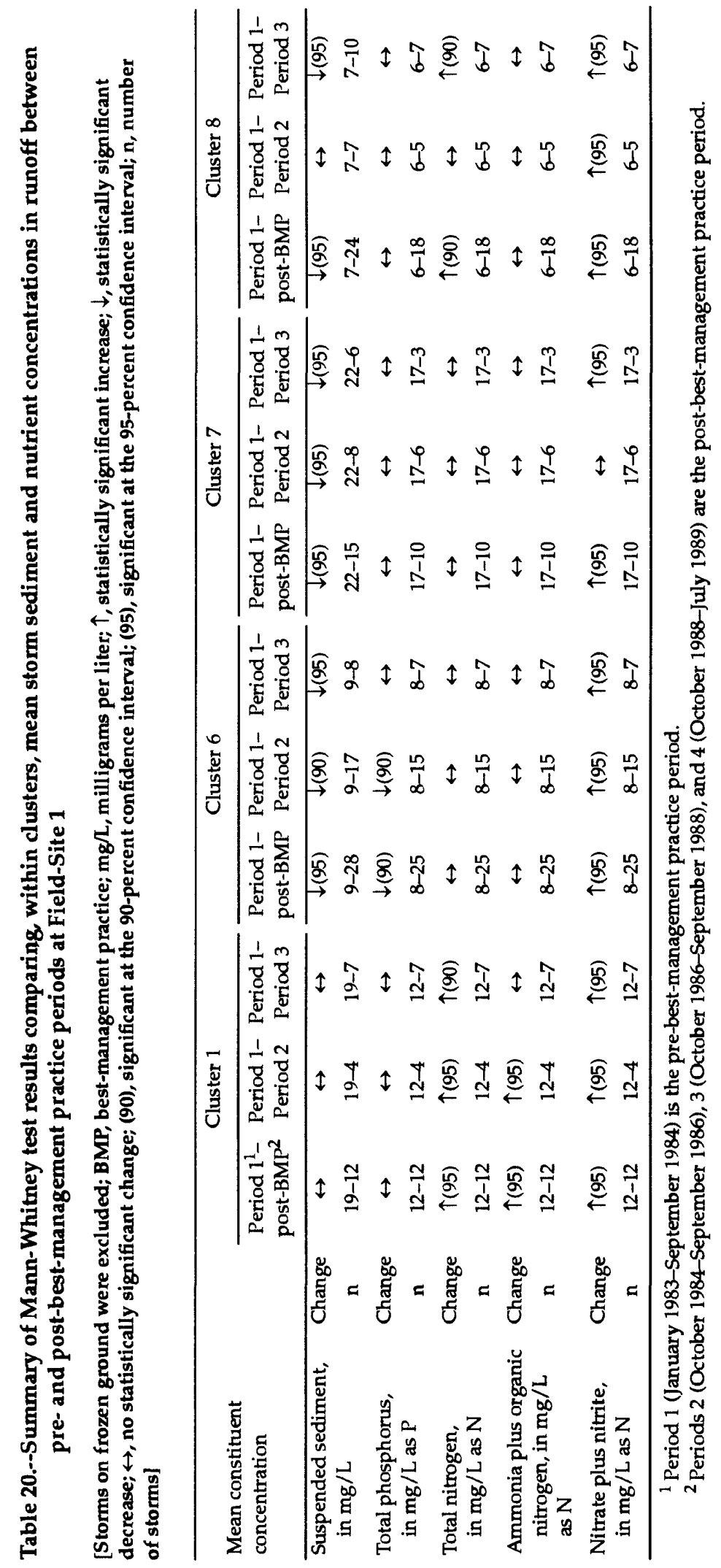




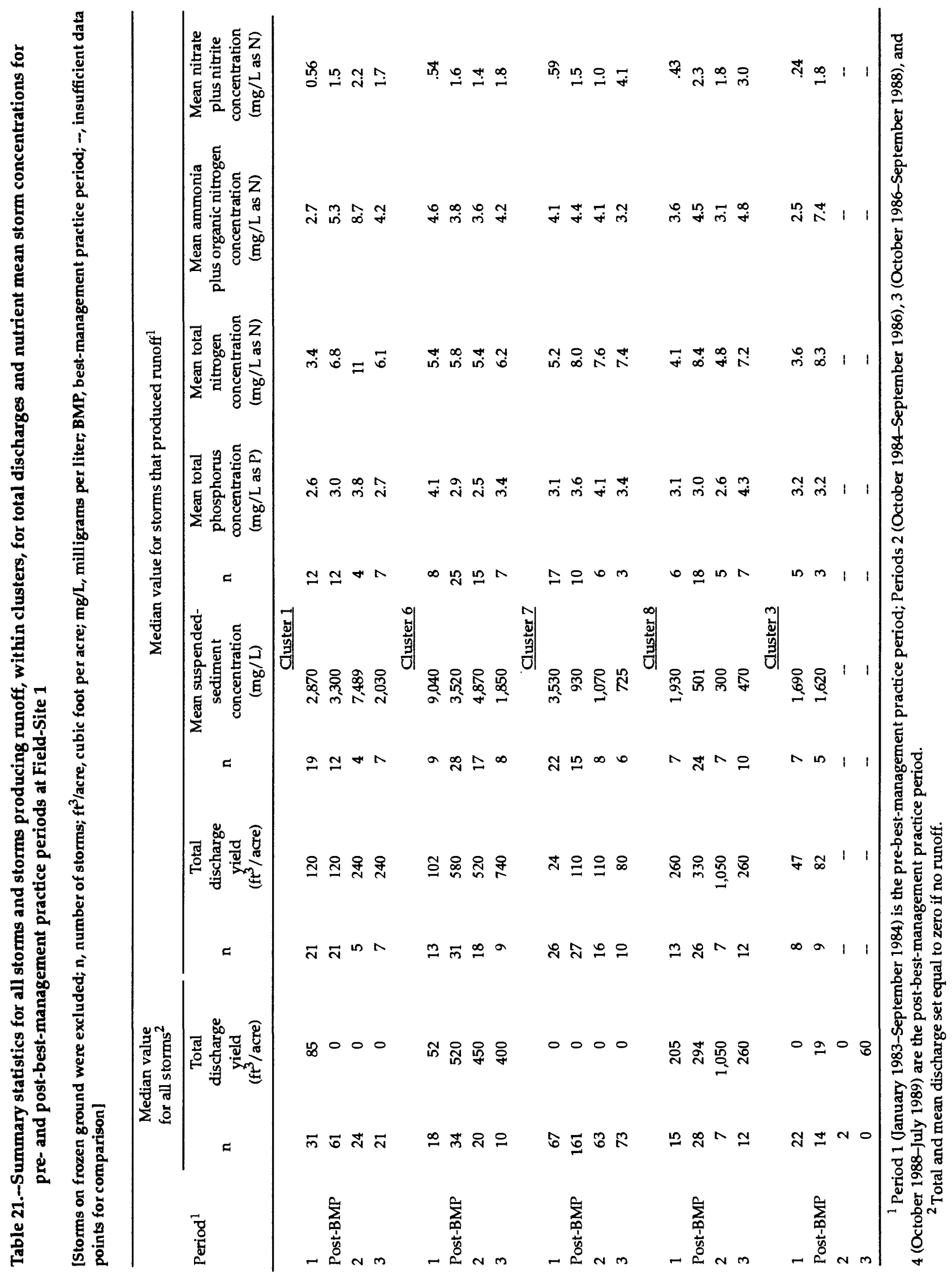




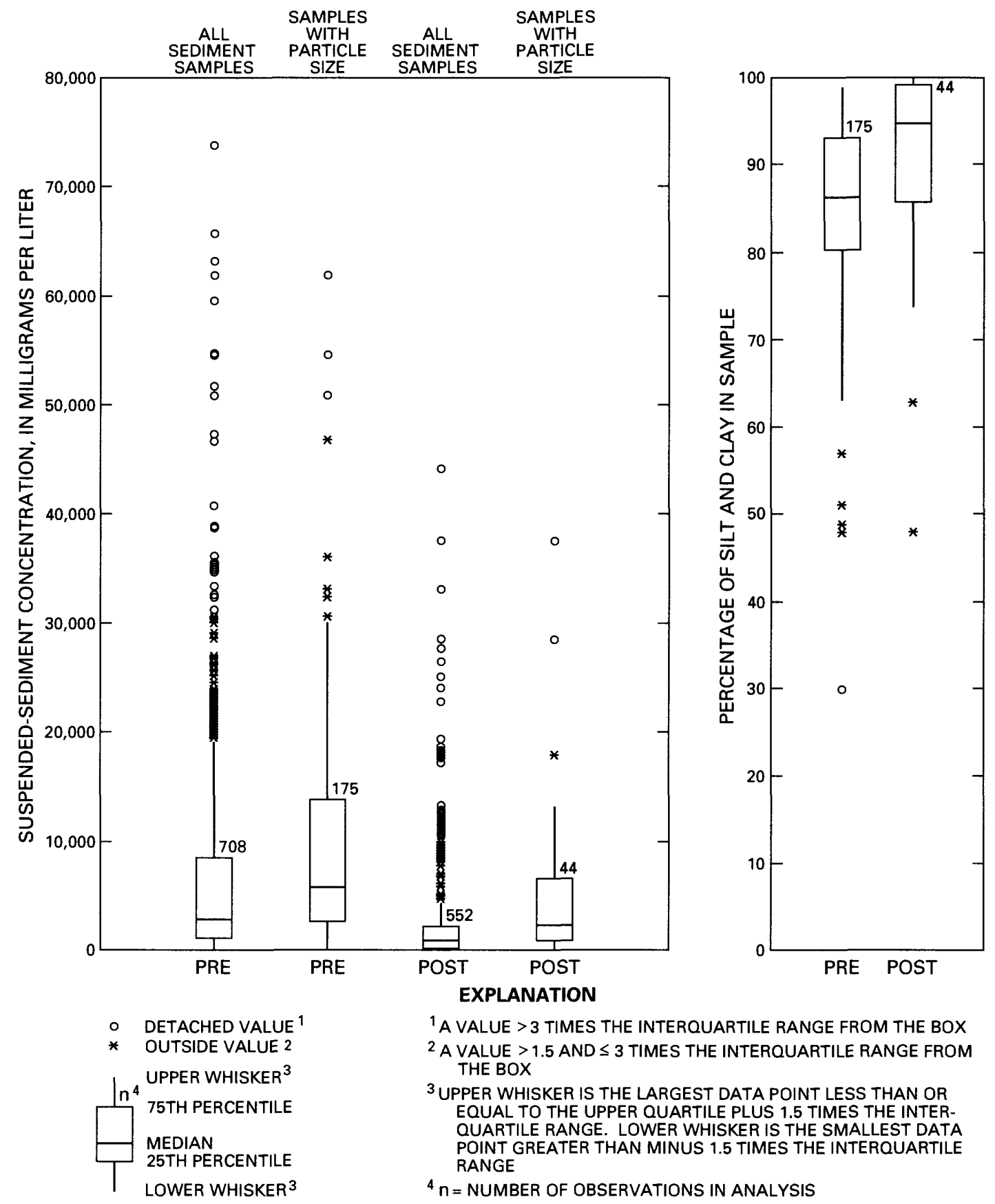

Figure 19.--Suspended-sediment concentrations in all samples and in samples analyzed for particle size (left), and percentage of silt and clay in samples analyzed for particle size (right) during the pre-best-management practice Period 1 (January 1983-September 1984) and part of the post-best-management practice Periods 2 and 3 (October 1985September 1988) at Field-Site 1. 


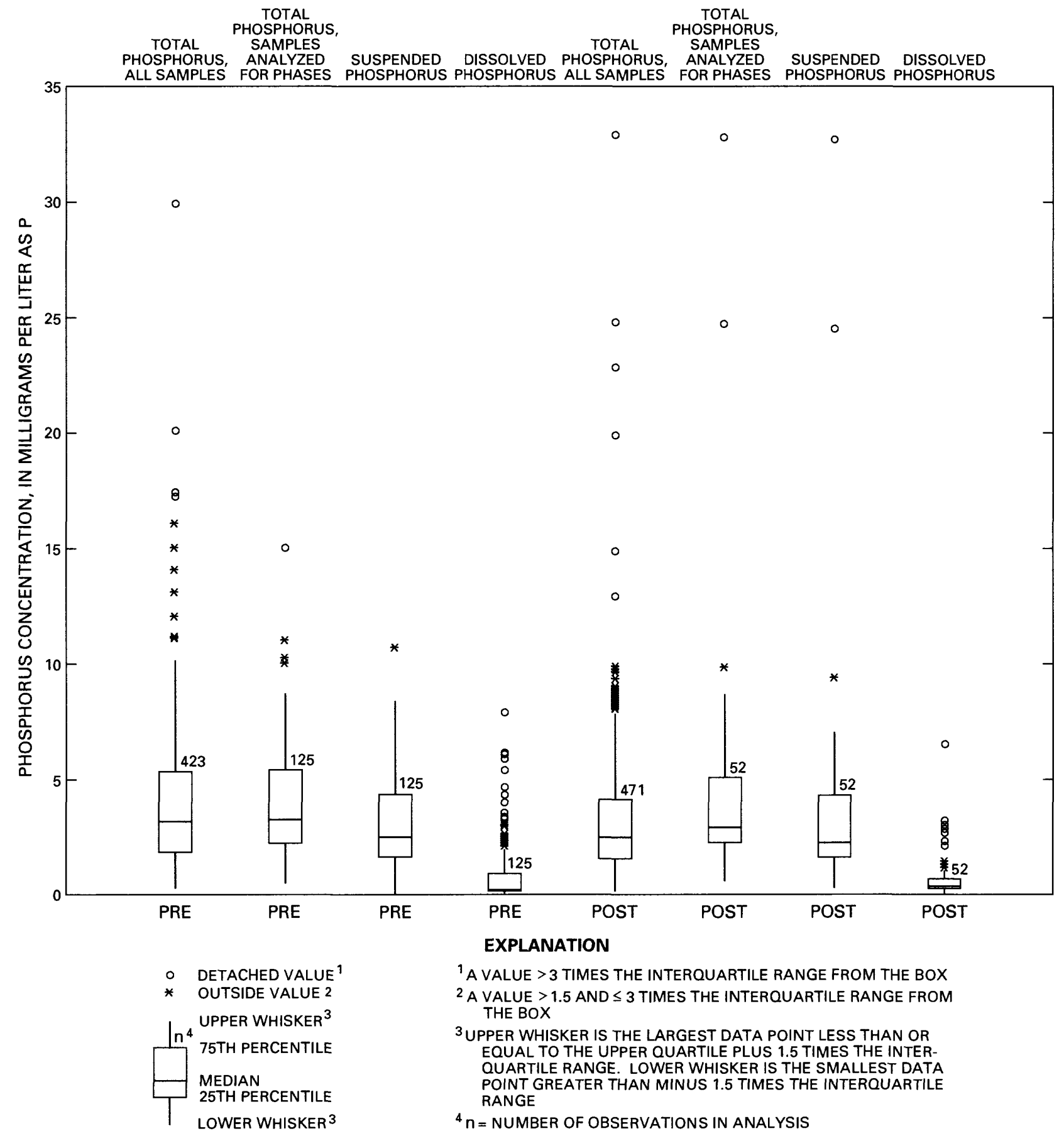

Figure 20.--Distribution of instantaneous total phosphorus concentrations in all runoff samples and phase of phosphorus in a limited number of samples during the pre-best-management practice Period 1 (January 1983September 1984) and part of the post-best-management practice Periods 2 and 3 (October 1985September 1988) at Field-Site 1. 


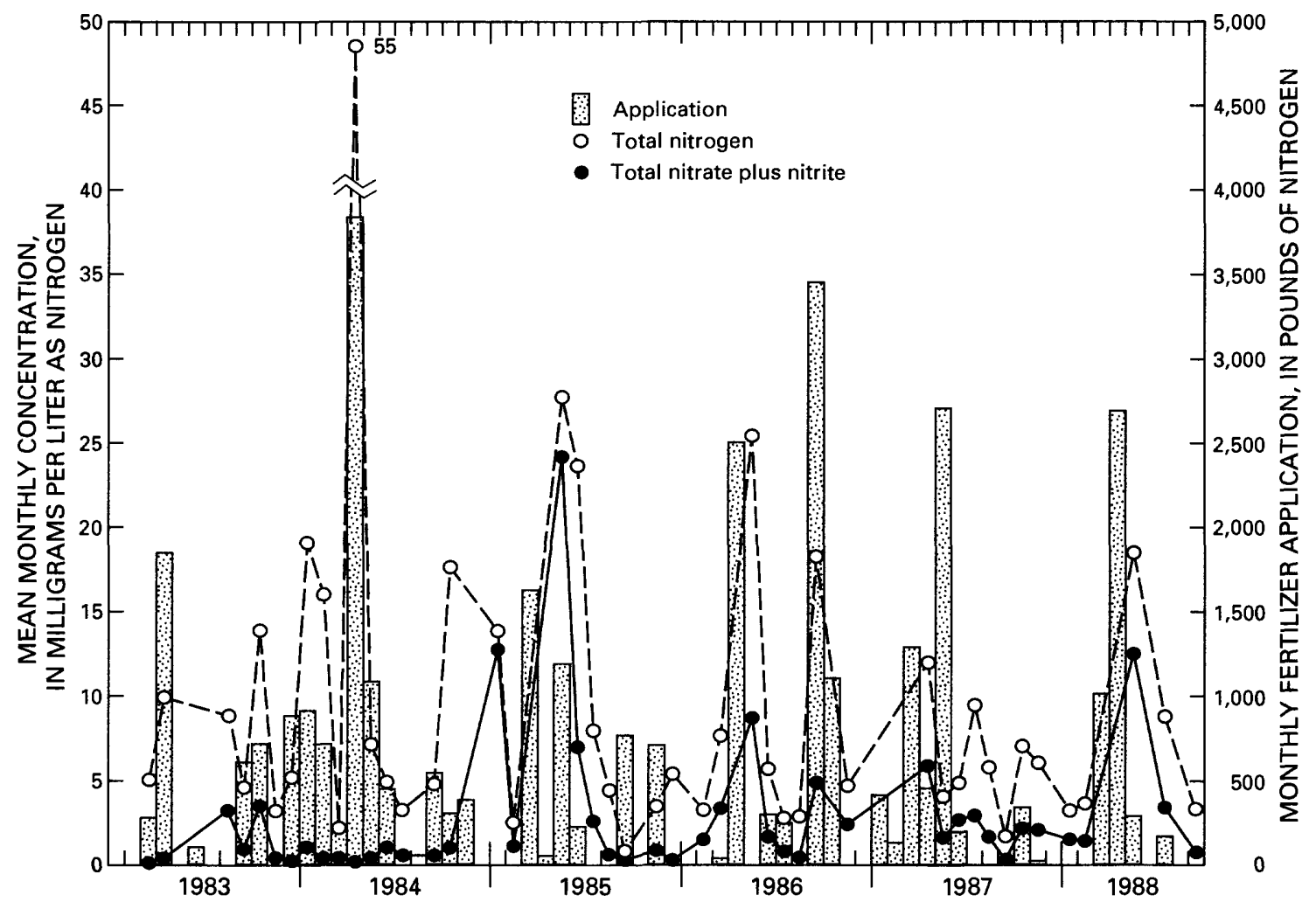

Figure 21.--Mean monthly water-weighted total nitrogen and total nitrate plus nitrite concentrations in runoff from sampled storms and total monthly nitrogen application to Field-Site 1.

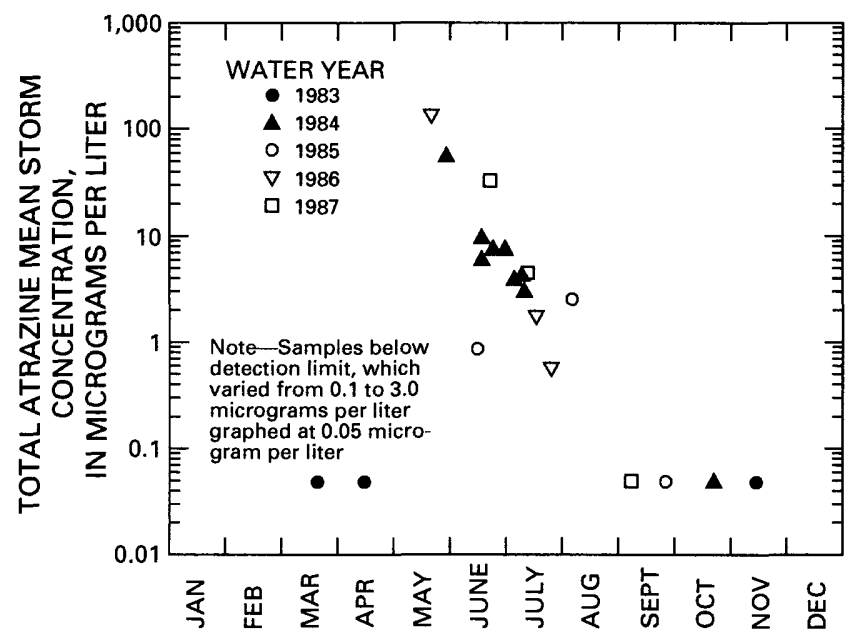

Figure 22.--Mean flow-weighted storm concentration of atrazine at Field-Site 1 for the 1983-87 water years. 


\section{EFFECTS OF PIPE-OUTLET TERRACING ON QUANTITY AND QUALITY OF GROUND WATER}

The ground-water basin at Field-Site 1 is slightly larger than the surface-water basin (fig. 23). Boundaries of the ground-water basin were estimated from measured water levels of wells drilled in the study area (table 22), site hydrogeology, and topography (Lietman and others, 1996). Solutional enlargements along bedding planes, fractures, joints, and rock cleavage form the dominant pathways for ground-water flow. Discharge from the ground-water flow system occurs along the eastern site boundary along the Conestoga River and its unnamed tributary.

Unsaturated-zone materials at the site are 5 to $70 \mathrm{ft}$ thick and are very permeable. Secondary porosity in the soils and regolith of the unsaturated zone caused by worm holes, root channels, and subsurface erosion (including sinkholes) facilitates the rapid movement of water and dissolved chemicals from the land surface to the water table. Ground-water levels at the site responded to recharge within several hours to a day. Terracing did not affect the rapid water-level response of the aquifer to recharge, as indicated by the well hydrographs (fig. 24).

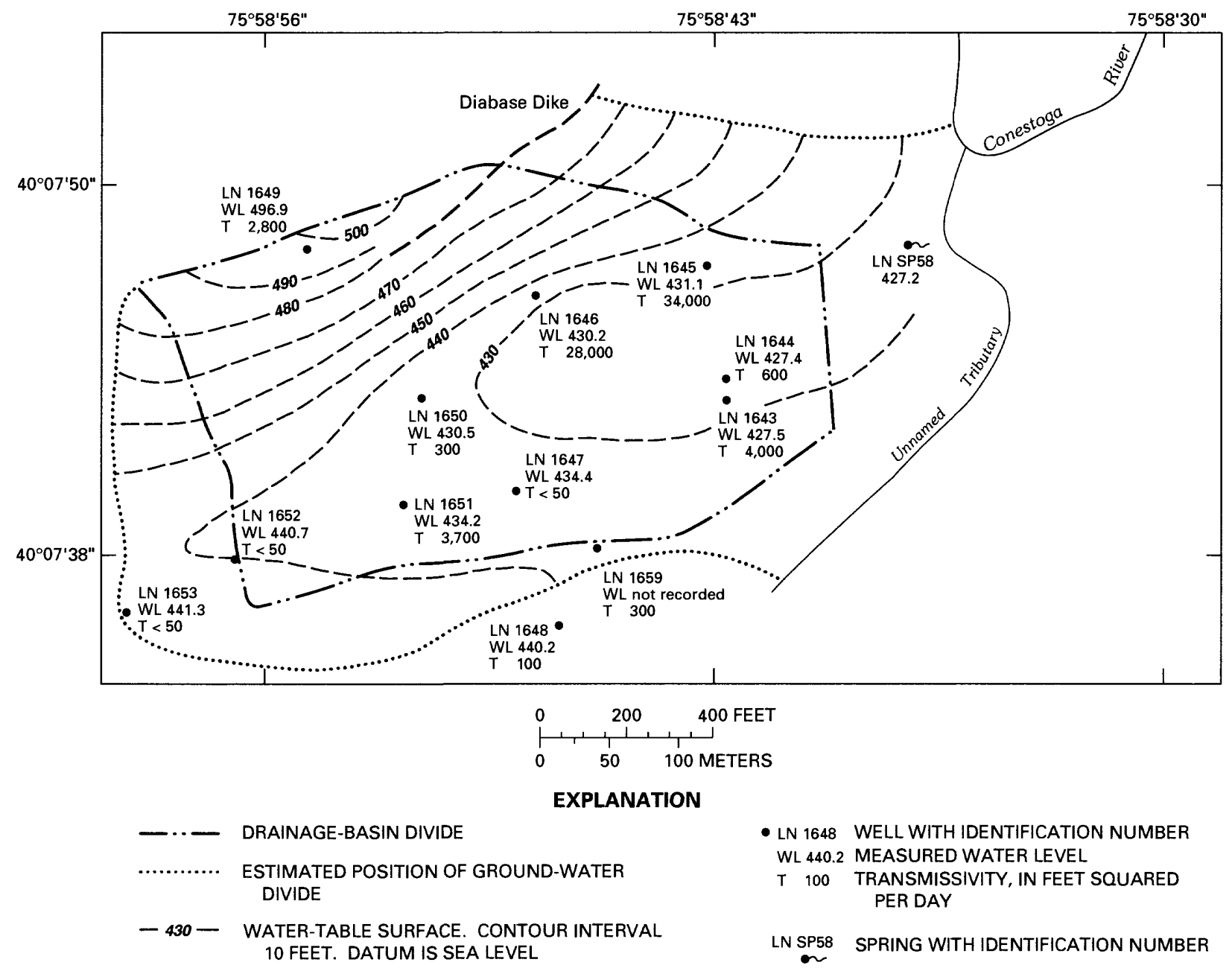

Figure 23.--Estimated water-table configuration at Field-Site 1 on November 2, 1982, and transmissivities of the Zooks Corner Formation. 
Table 22.--Locations and descriptions of ground-water data-collection sites at Field-Site 1

[All depths shown in feet below land surface; (gal/min)/ft, gallon per minute per foot; <, less than, E, estimated value; NA, not applicable; --, no data; N, nutrient data only; + I, major-ion data; NWL, nutrient and continuous water-level data; WL, intermittent water-level data only; NWLP, nutrient, continuous water-level, and herbicide data]

\begin{tabular}{|c|c|c|c|c|c|c|c|c|c|c|}
\hline \multirow{2}{*}{$\begin{array}{l}\text { Well } \\
\text { number }\end{array}$} & \multirow{2}{*}{$\begin{array}{l}\text { Latitude } \\
\text { (in degrees, } \\
\text { minutes, and } \\
\text { seconds) }\end{array}$} & \multirow{2}{*}{$\begin{array}{l}\text { Longitude } \\
\text { (in degrees, } \\
\text { minutes, and } \\
\text { seconds) }\end{array}$} & \multirow{2}{*}{$\begin{array}{l}\text { TotaI } \\
\text { depth } \\
\text { of well }\end{array}$} & \multirow{2}{*}{$\begin{array}{l}\text { Depth of } \\
\text { bottom } \\
\text { of casing } \\
\text { (overburden } \\
\text { thickness) }\end{array}$} & \multirow{2}{*}{$\begin{array}{l}\text { Depth to } \\
\text { bedrock }\end{array}$} & \multicolumn{2}{|c|}{$\begin{array}{c}\text { Depth to water } \\
\text { table surface, } \\
1983-89\end{array}$} & \multirow{2}{*}{$\begin{array}{c}\text { Specific } \\
\text { capacity } \\
{[(\mathrm{gal} / \mathrm{min}) / \mathrm{ft}]}\end{array}$} & \multirow{2}{*}{$\begin{array}{c}\text { Data } \\
\text { collected }\end{array}$} & \multirow{2}{*}{$\begin{array}{c}\text { Sampling } \\
\text { depth } \\
\text { (feet) }\end{array}$} \\
\hline & & & & & & $\begin{array}{c}\text { Maximum } \\
\text { (lowest } \\
\text { water Ievel) }\end{array}$ & $\begin{array}{c}\text { Minimum } \\
\text { (highest } \\
\text { water level) }\end{array}$ & & & \\
\hline LN SP58 & 400744 & 755839 & Spring & NA & NA & NA & $\overline{N A}$ & $\mathrm{NA}$ & $\bar{N}+1$ & NA \\
\hline LN 1643 & 400741 & 755843 & 100 & 68.9 & 20 & 38.75 & 33.66 & 20 & NWL + I & 82 \\
\hline LN 1644 & 400742 & 755843 & 75 & 77.6 & 22 & - & -- & 30 & WL & 43 \\
\hline LN 1645 & 400746 & 755843 & 80 & 24.2 & 7 & 52.53 & 49.00 & 160 & NWLP + I & 62 \\
\hline LN 1646 & 400744 & 755847 & 125 & 99.4 & 5 & 73.21 & 69.47 & 130 & NWLP + I & 107 \\
\hline LN 1647 & 400740 & 755849 & 75 & 37.3 & 17 & -- & - & $<.25$ & $W L+1$ & 65 \\
\hline LN 1648 & 400738 & 755846 & 100 & 7.2 & 2 & -- & -- & .50 & $\mathbf{W L}+1$ & 72 \\
\hline LN 1649 & 400744 & 755854 & 85 & 38.7 & 35 & 37.94 & 29.35 & 14 & NWL + I & 72 \\
\hline LN 1650 & 400741 & 755851 & 125 & 89.7 & 63 & 74.52 & 70.14 & 36 & $N W L+1$ & 112 \\
\hline LN 1651 & 400739 & 755851 & 105 & 71.7 & 68 & 71.27 & 62.65 & 20 & $N W L+1$ & 92 \\
\hline LN 1652 & 400738 & 755853 & 125 & 79.5 & 12 & -- & -- & $<.25$ & $W L+1$ & 83 \\
\hline LN 1653 & 400737 & 755856 & 132 & 105.1 & 27 & -- & -- & 3.0 & $W L+1$ & 117 \\
\hline LN 1659 & 400739 & 755845 & 142 & E84 & 18 & -- & -- & .50 & WL & 98 \\
\hline LN 1660 & 400745 & 755853 & 150 & 39.2 & 12 & -- & -- & .75 & $W L$ & 73 \\
\hline LN 1661 & 400744 & 755856 & 75 & 38.5 & 20 & - & -- & 3.0 & $W L$ & 63 \\
\hline
\end{tabular}

The average specific yield of the saturated ground-water flow system at the site was estimated to be 0.13 , on the basis of water-level rises measured in well LN 1643 during recharge events occurring under conditions of high antecedent soil-water saturation and negligible evapotranspiration (as described by Gerhart, 1986; Lietman and others, 1996). Estimated specific capacities of the wells ranged from less than 1 to $160(\mathrm{gal} / \mathrm{min}) / \mathrm{ft}$; the median specific capacity was $9(\mathrm{gal} / \mathrm{min}) / \mathrm{ft}$. Transmissivity was calculated from estimates of specific capacity and a Darcy's law calculation. Transmissivities ranged over more than three orders of magnitude at the site, from less than 50 to $34,000 \mathrm{ft}^{2} / \mathrm{d}$ (Lietman and others, 1996).

\section{Quantity}

Percentages of precipitation that recharged ground water and amounts of ground-water discharge from the site decreased during the study period after terracing (fig. 24; table 23), however, terracing did not cause the decreases. Quantity and temporal distribution of precipitation and climatic and agricultural-activity factors that affected evapotranspiration rates were probably responsible for the decreased recharge. The hydrograph from well LN 514, located in a carbonate area where no land-contouring changes occurred, was compared to the hydrographs of site wells (fig. 24). Well LN 514 (latitude $40^{\circ} 05^{\prime} 06^{\prime \prime}$, longitude $76^{\circ} 23^{\prime} 52^{\prime \prime}$ ) is located in Landisville, Pa., approximately $11 \mathrm{mi}$ from Field-Site 1 . The proportional similarity in the shapes of the hydrographs of well LN 514 and the Field-Site 1 wells suggests that climatic factors caused decreased amounts of recharge to ground water during Periods 2,3, and 4 relative to Period 1. 

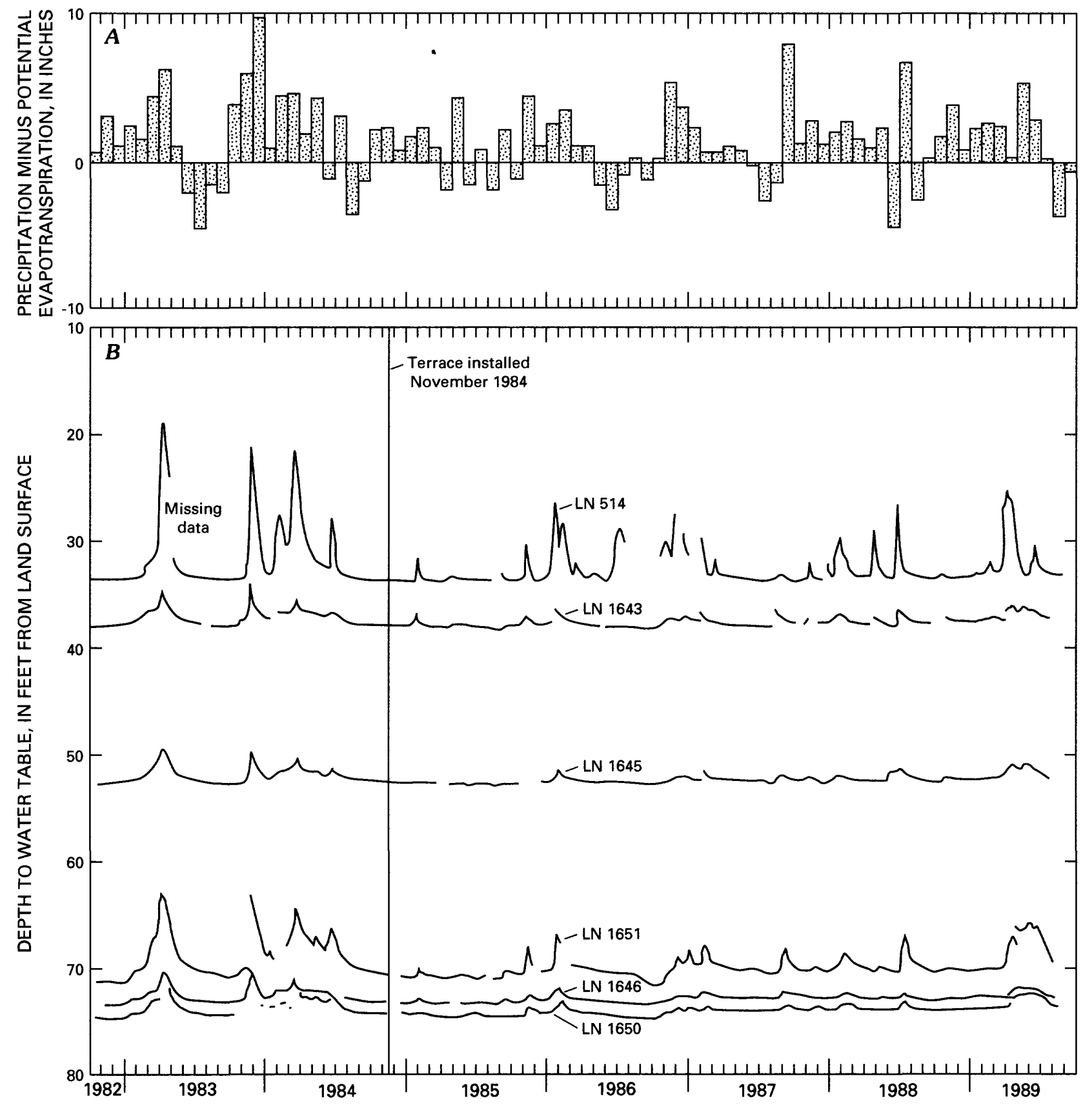

Figure 24.-- $A$, Precipitation minus potential evapotranspiration. $B$, Depth to water table from land surface at well LN 514, 11 miles from Field-Site 1, and at wells LN 1643, LN 1645, LN 1646, LN 1650, and LN 1651 at Field-Site 1 for water years 1983-89.

On the basis of average monthly recharge estimates from Field-Site 1, recharge during Period 1 was about 88 percent greater than during Period 2, 54 percent greater than during Period 3, and 22 percent greater than during Period 4. Precipitation during Period 1 was about 25, 19, and 8 percent greater than during Periods 2, 3, and 4, respectively; the precipitation distribution varied from year to year (fig. 3 ). When both precipitation and evapotranspiration are considered, more water was available for recharge prior to terracing, particularly during 1984 (fig. 24). 
Table 23.--Percentage of precipitation that recharged ground water, ground-water discharge, and dissolved nitrate yields in ground water from Field-Site 1

INitrate concentration data from well $\mathrm{LN} 1645 ; \mathrm{ft}^{3}$ /acre, cubic foot per acre; lb/acre, pound per acrel

\begin{tabular}{llccc}
\hline Period ${ }^{1}$ & Dates & $\begin{array}{c}\text { Percentage of } \\
\text { precipitation } \\
\text { that recharged } \\
\text { ground water }\end{array}$ & $\begin{array}{c}\text { Ground-water } \\
\text { discharge } \\
\left(\mathrm{ft}^{3} / \text { acre) }\right.\end{array}$ & $\begin{array}{c}\text { Dissolved } \\
\text { nitrate } \\
\text { yield } \\
\text { (lb/acre) }\end{array}$ \\
\hline 1 & Jan. 1-Sept. 30, 1983 & 47 & 53,400 & 36 \\
2 & Oct. 1, 1983-Sept. 30, 1984 & 42 & 90,800 & 63 \\
3 & Oct. 1, 1984-Sept. 30, 1985 & 29 & 43,300 & 32 \\
& Oct. 1, 1985-Sept. 30, 1986 & 31 & 40,300 & 32 \\
4 & Oct. 1, 1986-Sept. 30, 1987 & 37 & 62,200 & 48 \\
& Oct. 1, 1987-Sept. 30, 1988 & 37 & 55,400 & 41 \\
\hline
\end{tabular}

${ }^{1}$ Period 1 (January 1983-September 1984) is the pre-best-management practice period; Periods 2 (October 1984-September 1986), 3 (October 1986-September 1988), and 4 (October 1988-July 1989) are the post-best-management practice period.

Terracing did not affect the water-table altitude at the site. The annual mean water-level altitude changed less than 0.5 percent at wells LN 1643, LN 1645, LN 1646, LN 1650, or LN 1651 during the study period. Annual mean water-level altitudes for the wells ranged from 428 to $437 \mathrm{ft}$ above sea level.

Additionally, no statistically significant changes in the quantity of recharge to the aquifer at the site were caused by terracing of the site. Water-level data from wells located in the terraced areas of the site were compared to water-level data from a well located outside of the terraced areas by use of double-mass curves (Searcy and Hardison, 1960) to determine if terracing changed quantities or spatial distribution of recharge to ground water. Double-mass curves are based on the fact that cumulatively summed data of a quantity will plot as a straight line against another quantity if changes occurring in the data are proportional; the slope of the line represents the constant of proportionality. A break in the slope of a double-mass curve, such as a break in a curve of water-level data occurring at a time of terrace construction, can mean that a significant change occurred between the two quantities.

Because the numerical values of water-table altitudes (for example, $428 \mathrm{ft}$ above sea level) were very large relative to small changes (for example, a 1-ft rise) in water-table altitude caused by a recharge event, double-mass plots of data that include the water-table altitude are insensitive to small changes in water-level altitude caused by recharge. Therefore, monthly data residuals, the monthly mean water levels for a well minus the minimum water-table altitude for the period of record at a well were used to improve sensitivity of the method (Searcy and Hardison, 1960). Double-mass curves of the cumulative summed residual data are shown on figures 25 and 26.

Water-level data from well LN 1659, upgradient of the terraced areas of the site, were used for double-mass comparison to water-level data from other wells within the terraced area of the site. Although well LN 1659 is located outside of the surface-water divide, it is located within the ground-water divide. Ground water could have been laterally transmitted from terraced areas in the vicinity of well LN 1659 through fracture-controlled flow. However, in the absence of tracer tests and other confirmatory data, water-level data from well LN 1659 were used as a control for the double-mass data analysis. 


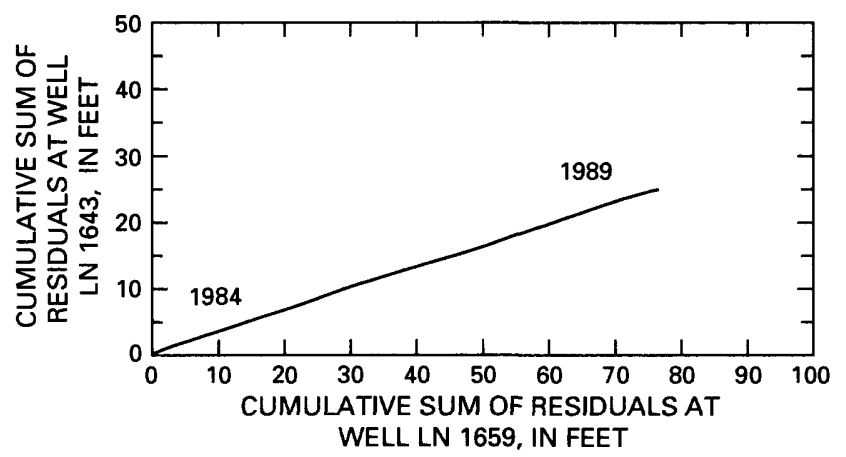

Figure 25.--Double-mass comparison of cumulative residuals from 1984 and 1989 water years at wells LN 1659 and LN 1643 at Field-Site 1.
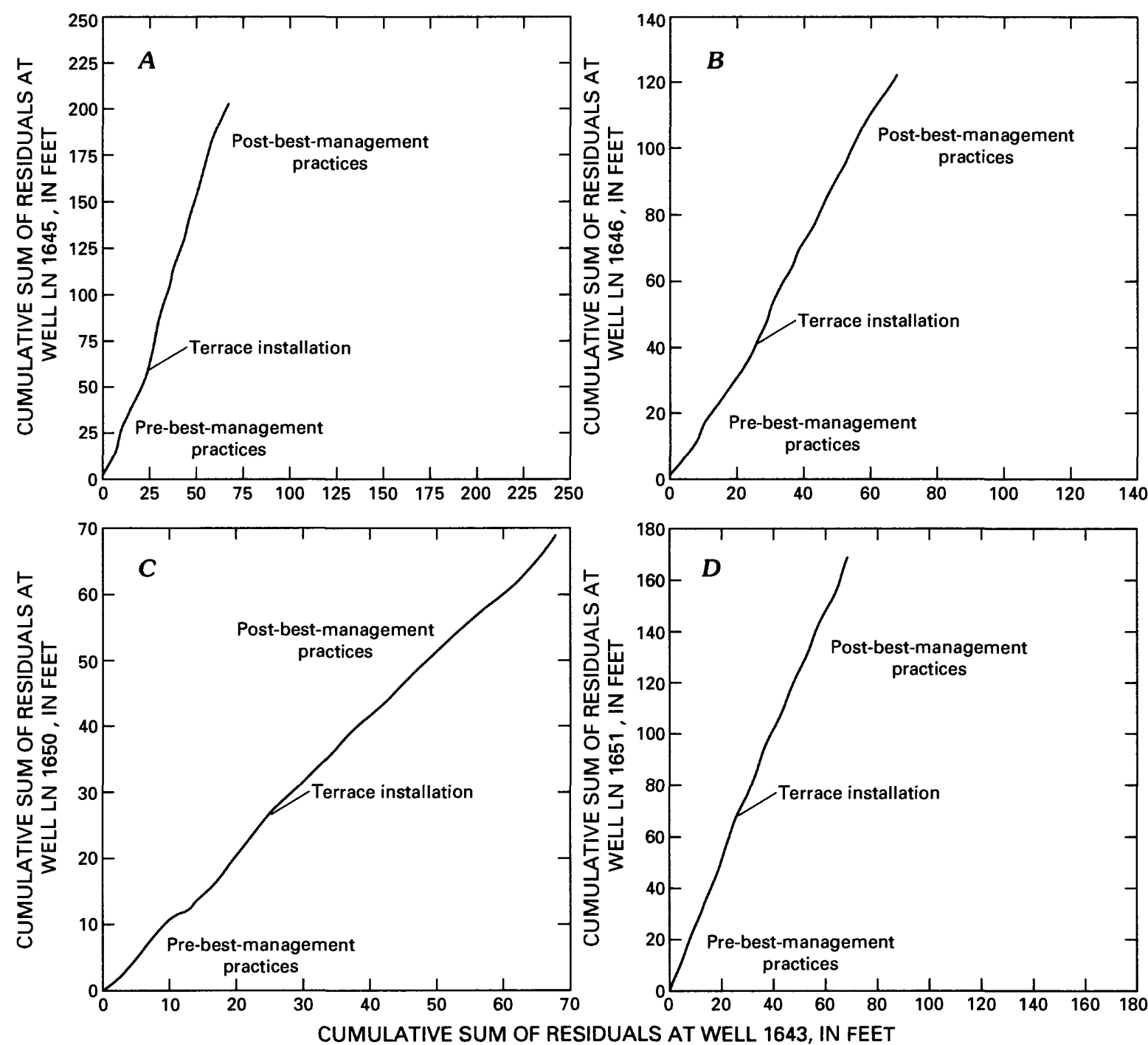

Figure 26.--Double-mass comparison of cumulative residuals from January 1983 through September 1989 at $\mathrm{LN} 1643$ (control well) and wells $A, \mathrm{LN} 1645 ; B, \mathrm{LN} 1646 ; C, \mathrm{LN} 1650$; and $D, \mathrm{LN} 1651$, at Field-Site 1. 
Although the water-level record from well LN 1659 is incomplete, sufficient record exists to establish that no significant change is present in the slope of the double-mass curve by the use of data from wells LN 1659 and LN 1643 between the 1984 water year and the 1989 water year (fig. 25). Therefore, it appears that no change in the amount of ground-water recharge occurred upgradient of well LN 1643, and the more complete water-level record from well LN 1643 (complete from January 1983 through September 1989) can be used as a control to gage the effects of terracing on the amounts of recharge at the other wells LN 1645, LN 1646, LN 1650, and LN 1651.

Analysis of covariance indicated that none of the breaks in slope of the double-mass curves of the water-level residuals of the other four wells as a function of the residuals of LN 1643 (fig. 26) were statistically significant. Therefore, terracing did not significantly change the amount of recharge to the aquifer at the site.

\section{Quality}

Ground-water quality at the site reflects the carbonate mineralogy of the aquifer. A limited number of major-ion analyses conducted during the pre-BMP period at 10 wells and the spring indicated that ground water is very hard ( 200 to $530 \mathrm{mg} / \mathrm{L}$ as calcium carbonate), is slightly alkaline (pH ranged from 7.0 to 7.7 ), and has a large buffering capacity (alkalinity ranged from 155 to $272 \mathrm{mg} / \mathrm{L}$ as calcium carbonate). Concentrations of dissolved oxygen in ground water from eight wells and the spring ranged from 1.4 to $10.6 \mathrm{mg} / \mathrm{L}$ (Lietman and others, 1996).

Specific conductances of ground water from the five wells that were monitored for changes in water level and water quality during the study period ranged from $405 \mu \mathrm{S} / \mathrm{cm}$ in water from well LN 1646 to $925 \mu \mathrm{S} / \mathrm{cm}$ in samples from well LN 1643. The range of specific conductance was controlled primarily by the dissolution of the carbonate rock at the site, as indicated by the concentrations of calcium, bicarbonate, and magnesium in ground water at the site (Lietman and others, 1996). Ions leached from manure and agricultural chemicals applied to the site probably also contributed to the specific conductance of the ground water.

Concentrations of dissolved phosphorus in ground-water samples ranged from below detection limit at all wells to $0.11 \mathrm{mg} / \mathrm{L}$ in a sample collected at well LN 1651 . Phosphorus is only sparingly available for leaching to the ground water because it strongly sorbs to soil particles.

Concentrations of dissolved ammonia plus organic nitrogen in ground-water samples ranged from less than $0.2 \mathrm{mg} / \mathrm{L}$ in water from several wells to $4.6 \mathrm{mg} / \mathrm{L}$ as nitrogen in water from well LN 1643. Concentrations were generally less than $1.0 \mathrm{mg} / \mathrm{L}$. Ammonia concentrations in ground-water samples were small because ammonia ions, like phosphorus ions, sorb to soil particles and do not easily leach to ground water. Dissolved ammonia plus organic nitrogen and ammonia nitrogen contributed less than 10 percent of the total nitrogen in ground water at the site.

Concentrations of dissolved nitrite ranged from less than $0.01 \mathrm{mg} / \mathrm{L}$ to a maximum of $0.38 \mathrm{mg} / \mathrm{L}$ in a sample from well LN 1646. Median concentrations of dissolved nitrite were below the detection limit in samples collected at the five wells and the spring selected for water-quality monitoring during the post-BMP period. Nitrite is typically a short-lived transition product that forms as an intermediate in the oxidation of ammonia to nitrate.

Dissolved nitrate comprised 99.9 percent of the dissolved nitrate plus nitrite; therefore, nitrate plus nitrite results are referred to as dissolved nitrate in this report. Nitrate concentrations in ground water commonly exceeded the USEPA maximum contaminant level (MCL) of $10 \mathrm{mg} / \mathrm{L}$ nitrate as nitrogen (U.S. Environmental Protection Agency, 1992). Nitrate concentrations (fig. 27) in samples from the five monitor wells ranged from a minimum of $4.8 \mathrm{mg} / \mathrm{L}$ in a sample from well LN 1646 to a maximum of $33 \mathrm{mg} / \mathrm{L}$ in a sample from well LN 1643. Dissolved nitrate moves readily from the land surface to ground water with recharge and accounted for over 90 percent of total nitrogen in ground water at the site. Therefore, nitrate was considered to be a good indicator of the effects of BMP implementation on ground-water quality. 


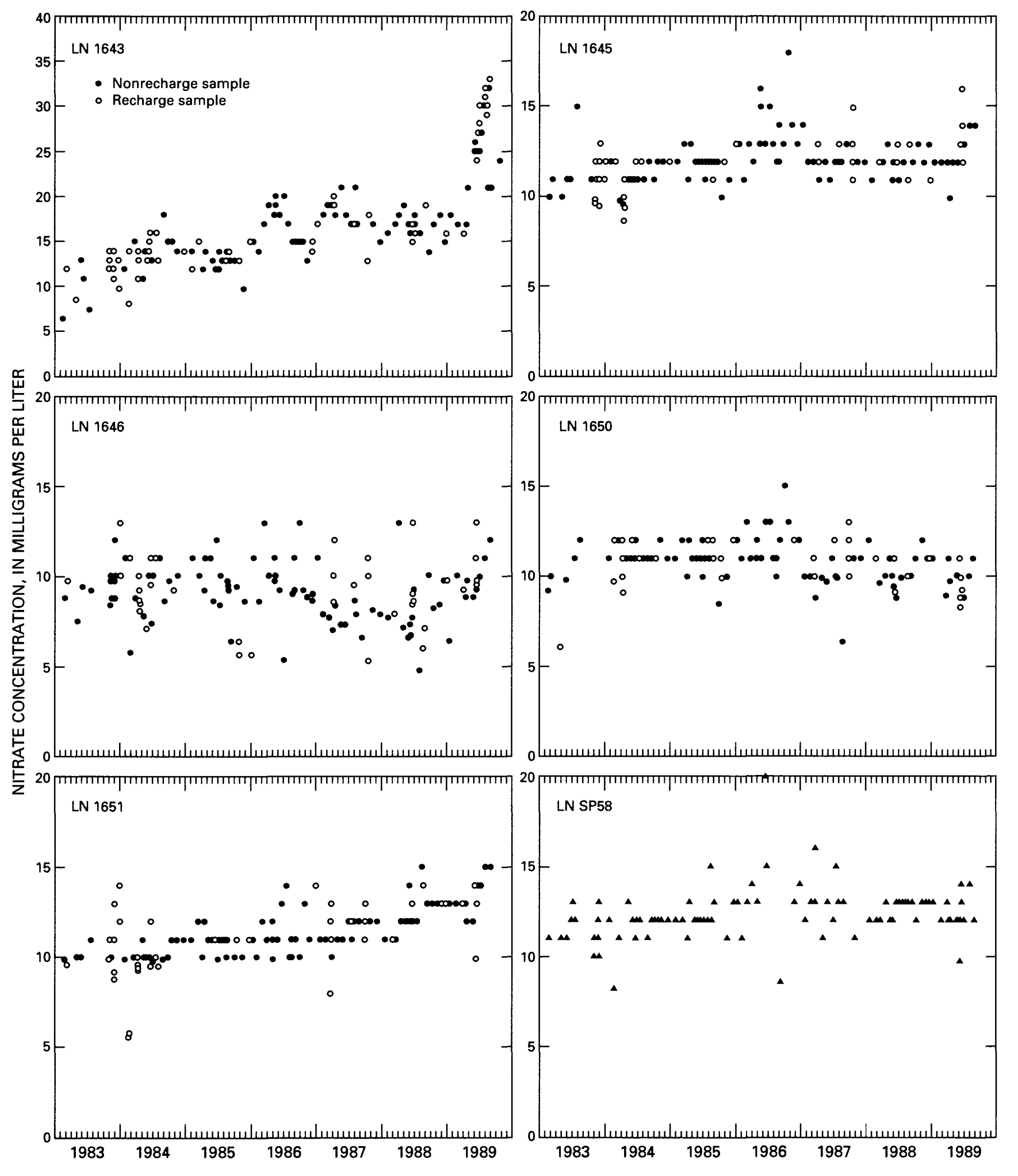

Figure 27.--Concentrations of nitrate (as nitrogen) in recharge and nonrecharge samples at Field-Site 1 collected at wells $L N 1643, L N 1645, L N 1646, L N 1650$, and $L N 1651$ and concentrations of all nitrate samples collected at spring LN SP58. 
For the 79-month study period, an average of about 45 (lb/acre)/yr of dissolved nitrate was discharged from the ground water. The ground-water yields represent about 17 percent of the total nitrogen applied to the site during the study period.

Atrazine, cyanazine, metolachlor, and alachlor were the predominant herbicides detected in ground-water samples collected from wells LN 1645 and LN 1646 (the only wells sampled during the post-BMP period) (figs. 28 and 29). Atrazine, applied to cornfields at Field-Site 1 during each of the 7 years of the study period, was detected consistently in ground water. The largest and greatest number of detections were found close to the times of herbicide application each spring, although small concentrations of atrazine were persistent throughout the year. The maximum atrazine concentration was $1.7 \mu \mathrm{g} / \mathrm{L}$ in a sample collected at well $\mathrm{LN} 1646$ during September 1985. Cyanazine was applied to cornfields in the spring of 1987 and 1988. Although sampling for cyanazine in water samples from the site began in January 1983, the first detectable concentrations were found in samples collected in June 1987 after the May 1987 application. The maximum cyanazine concentration of $1.6 \mu \mathrm{g} / \mathrm{L}$ was in a sample collected at well LN 1645 during June 1988. Metolachlor was applied to cornfields in the spring of each year except in 1987. The maximum metolachlor concentration of $0.6 \mu \mathrm{g} / \mathrm{L}$ was in a sample collected at well LN 1645 during July 1985. Alachlor was reported to have been applied to Field-Site 1 only in 1981 and 1982, prior to the study period. Although alachlor was not reportedly applied to the site or detected in surface runoff during the study period, it was present at or near the detection limit in 76 percent of ground-water samples collected at wells LN 1645 and LN 1646 during the period April 1986 through September 1989. Alachlor was also found at concentrations of $50 \mu \mathrm{g} / \mathrm{L}$ in a soil sample from Field-Site 1 collected in May 1986. Because alachlor is not commonly found to be persistent in soils and ground water over 4-year periods, the presence of alachlor in a soil sample and in ground-water samples from April 1986 through September 1989 is unexplained. Pesticide management programs were not implemented at the site during the study period; therefore, no statistical comparisons of pre-BMP and post-BMP were made.

Assessment of the effects of agricultural activities and recharge on ground-water quality is complicated by a variety of factors. For example, recharge may take a complex path from the land surface to the water table (White, 1985), and ground water in the anisotropic, carbonate aquifer at the site follows complex flow paths that can be difficult to determine. Bacterial processes that convert organic nitrogen to ammonia and nitrate at the land surface, in the soils, and in the unsaturated and saturated zones are affected by changes in temperature and moisture and by herbicide applications (Stevenson, 1982). Additionally, the reported locations of nutrient and pesticide applications and volumes of materials applied to the site were only roughly outlined on reports from the farmer. Despite these complications, relations between agricultural activities and ground-water quality are evident in data collected at the site.

The effect of surface-applied material on ground-water quality at the site is illustrated in a graph of atrazine applications and ground-water concentrations over time (fig. 30). Atrazine was applied to cornfields at the site on May 23, 1984. At well LN 1645, recharge water from the first recharge event after application delivered atrazine to the water table through approximately $50 \mathrm{ft}$ of soils and weathered material in less than 1 day. Despite no additional applications, atrazine was detected at well LN 1645 through September, suggesting that some of the slow-moving, recharge waters traveling through the small channels and pores in the unsaturated zone continued to deliver atrazine to the water table (Gerhart, 1986).

Nitrogen applications made to the site shortly before a recharge event also resulted in increased nitrate concentrations in ground-water samples collected as soon as several hours after the onset of recharge (Gerhart, 1986). Rapid nitrate transport may have been caused by rapid flow through macropores in the unsaturated zone. Substantial changes in nitrate concentration of samples collected during nonrecharge periods lagged 1 to 3 months behind concentration changes during recharge periods. These changes probably were caused by nitrate loading of slower moving ground-water recharge traveling through micropores in the unsaturated zone (Lietman and others, 1996). Micropore recharge has a substantial contact time with soils and is therefore able to oxidize ammonia and leach nitrate if these species are present in the unsaturated zone. 

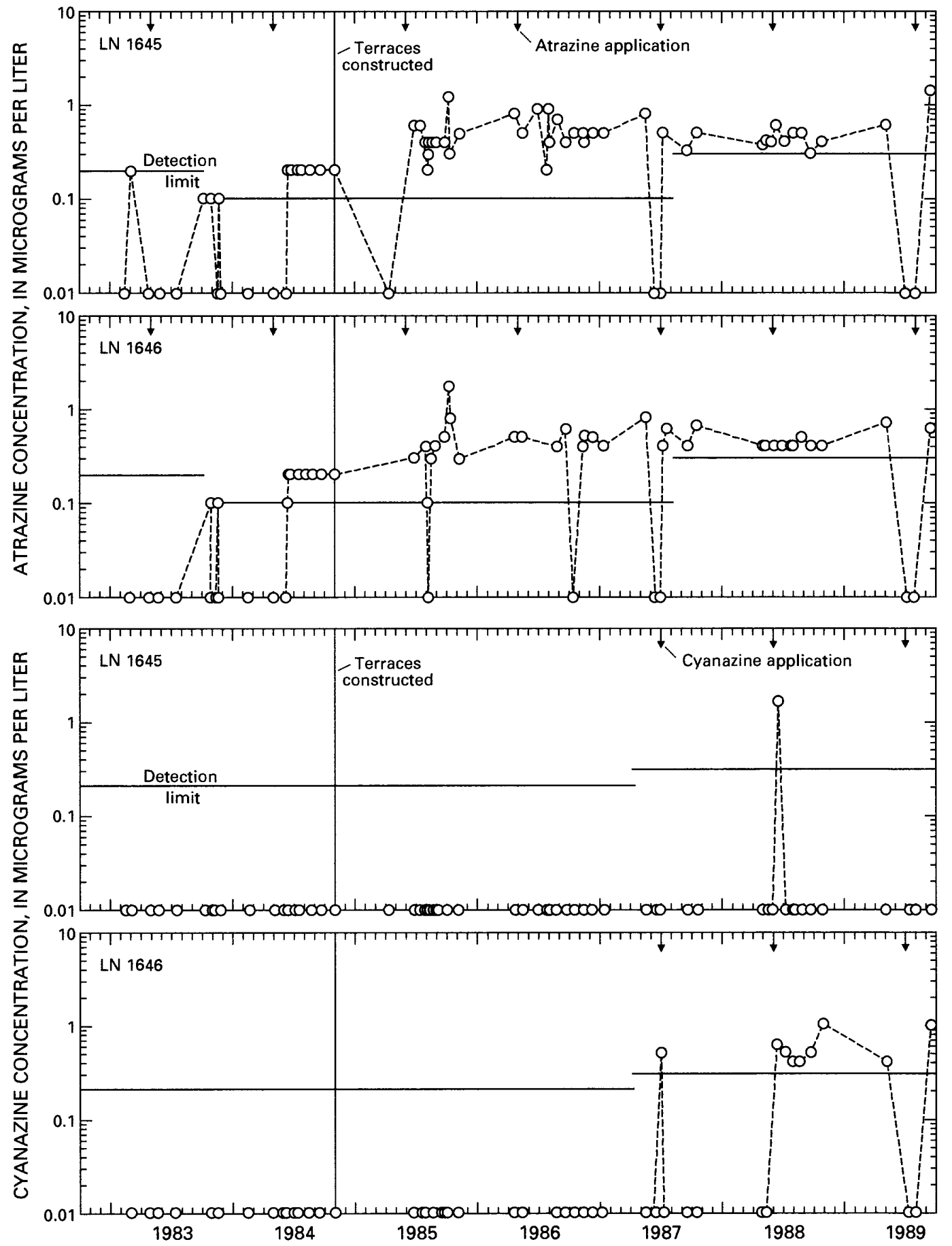

Figure 28.--Atrazine and cyanazine concentrations in water from wells $L N 1645$ and $L N 1646$ at Field-Site 1. (Note: Samples below the detection limit are graphed at 0.01 microgram per liter.) 

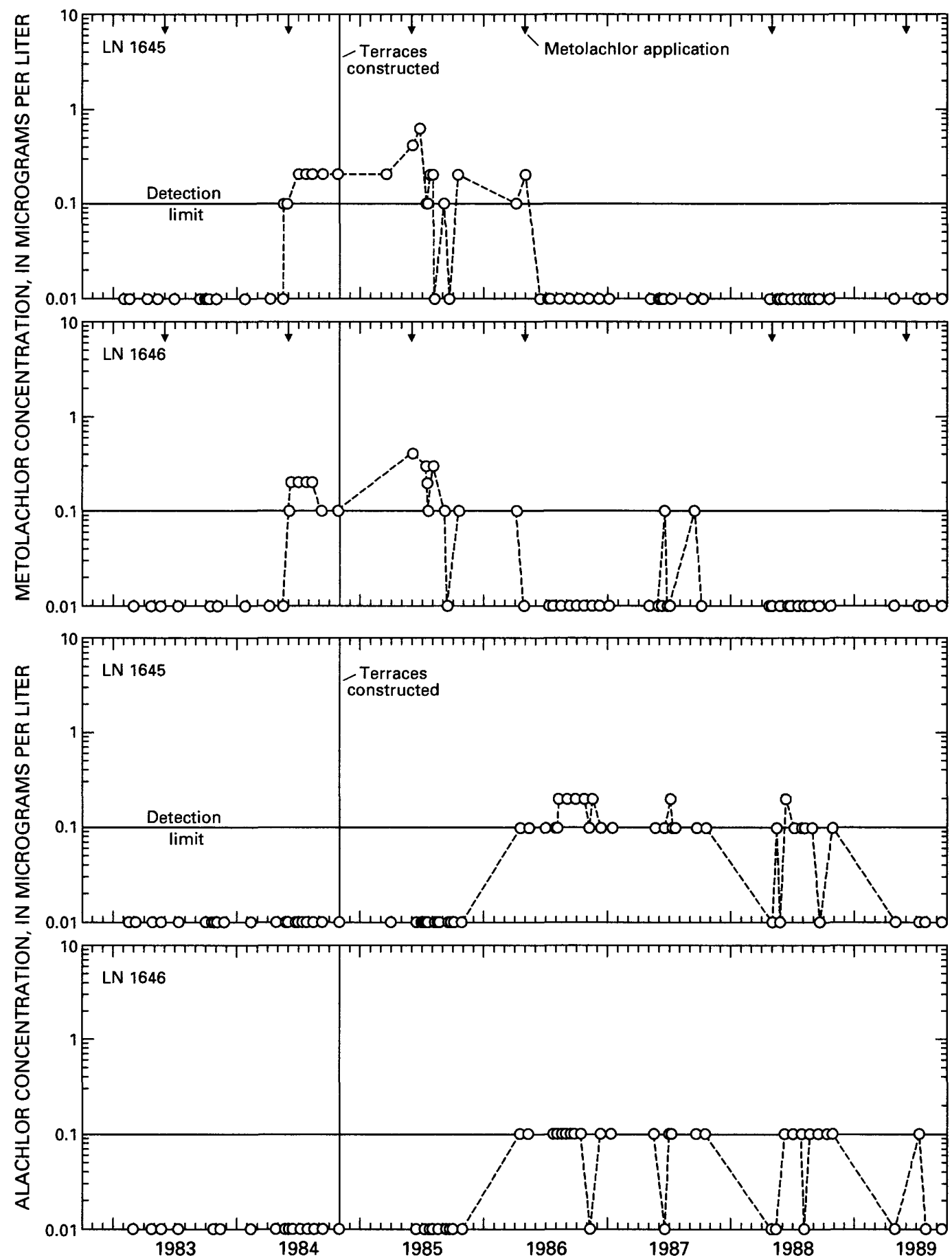

Figure 29.--Alachlor and metolachlor concentrations in water from wells LN 1645 and LN 1646 at Field-Site 1. (Note: Samples below the detection limit are graphed at 0.01 microgram per liter.) 


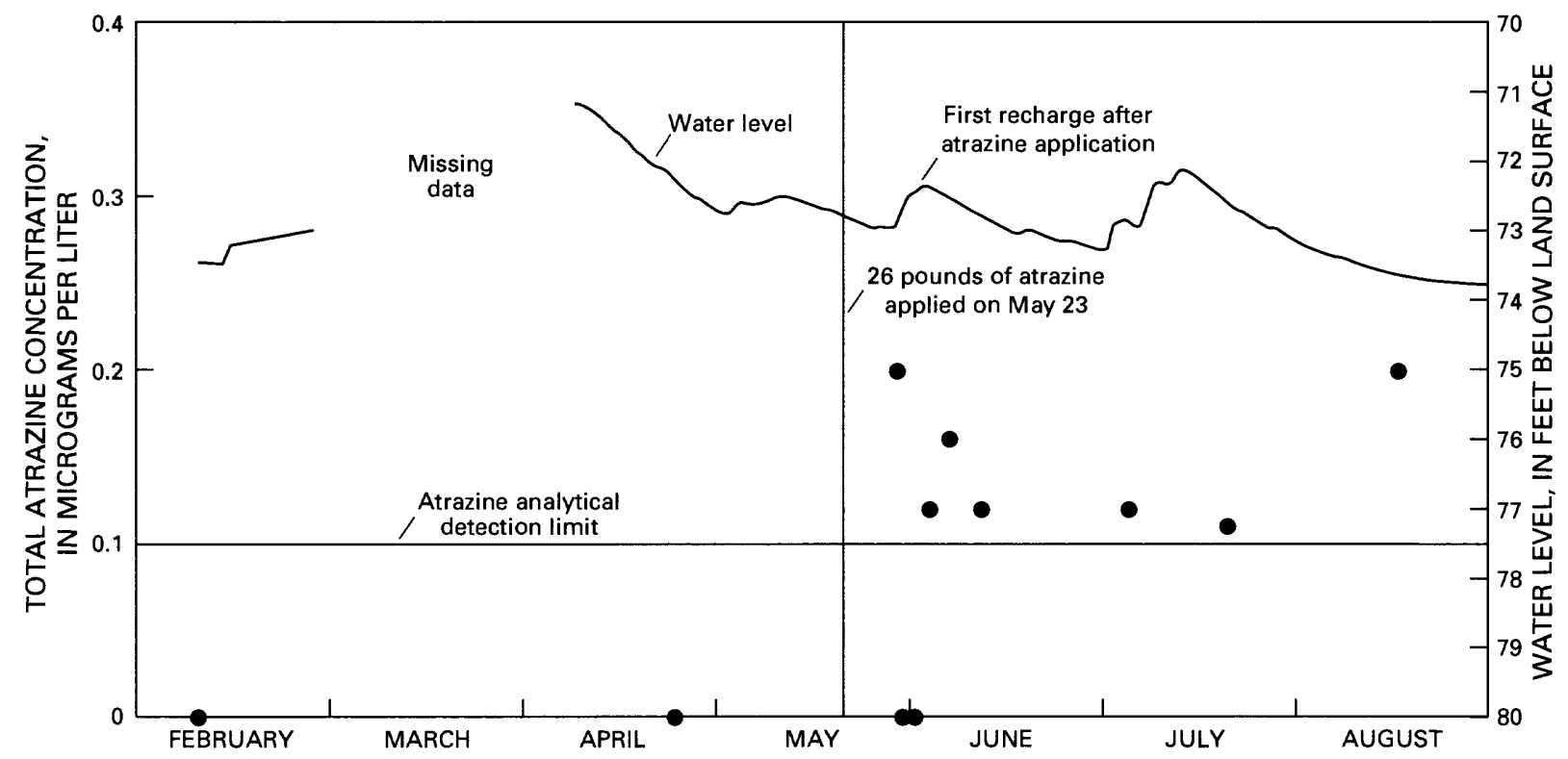

Figure 30.--Atrazine concentrations in water samples from well LN 1650 before and after atrazine application on May 23, 1984, at Field-Site 1. (Points shown at 0.0 are below the 0.1 microgram per liter detection limit.)

Because of the short-term effects of recharge events on nitrate concentrations at the site (Gerhart, 1986; Lietman and others, 1996), ground-water samples were divided into recharge and nonrecharge groups. Storms sufficiently large to produce an observable change in ground-water concentrations of nitrate were those where ground-water levels rose more than approximately $0.3 \mathrm{ft}$. Without additional recharge, groundwater hydrographs typically receded to near pre-storm levels within a 1-week period. Therefore, groundwater samples were empirically classified as recharge samples if they were collected within 1 week of a waterlevel rise of $0.3 \mathrm{ft}$ or greater. Ground-water samples were empirically classified as nonrecharge samples if they were not collected within 1 week of a 0.3 -ft or greater water-level rise.

Ground-water concentrations of nitrate in the nonrecharge samples increased significantly from Period 1 to each of the post-BMP periods at wells LN 1643, LN 1645, and LN 1651 and the spring LN SP58 (fig. 31, table 24) but did not change significantly at well LN 1650. For LN 1646, no change in median ground-water concentrations of nitrate occurred from Periods 1 to 2 and from 1 to 4 , but a statistically significant decrease occurred from Periods 1 to 3.

A qualitative assessment of the effects of BMP's on ground-water quality is based on documented changes in ground- and surface-water quality and corresponding terracing- and agricultural-activity data. A quantitative determination of the effects of BMP's on ground-water quality was not possible because of the complex changes that occurred at the site during the study, including terracing accompanied by cropping changes (as per USDA-Natural Resources Conservation Service contract), changes in nutrient applications from year to year and field to field, and the complex geology of the site.

The primary influences on changing ground-water quality from the pre-BMP to the post-BMP period were terracing and the amount and location of nitrogen applied to the field. Terrace construction did not substantially change the ground-water-table recharge. However, topography changes and ponding of runoff as a result of terrace construction probably modified the primary recharge areas of the aquifer that contributes water to wells. On the average, about $270 \mathrm{lb} /$ acre of nitrogen was applied to the site both during the pre- and post-BMP periods; most nitrogen was applied to the corn acreage (table 10). 


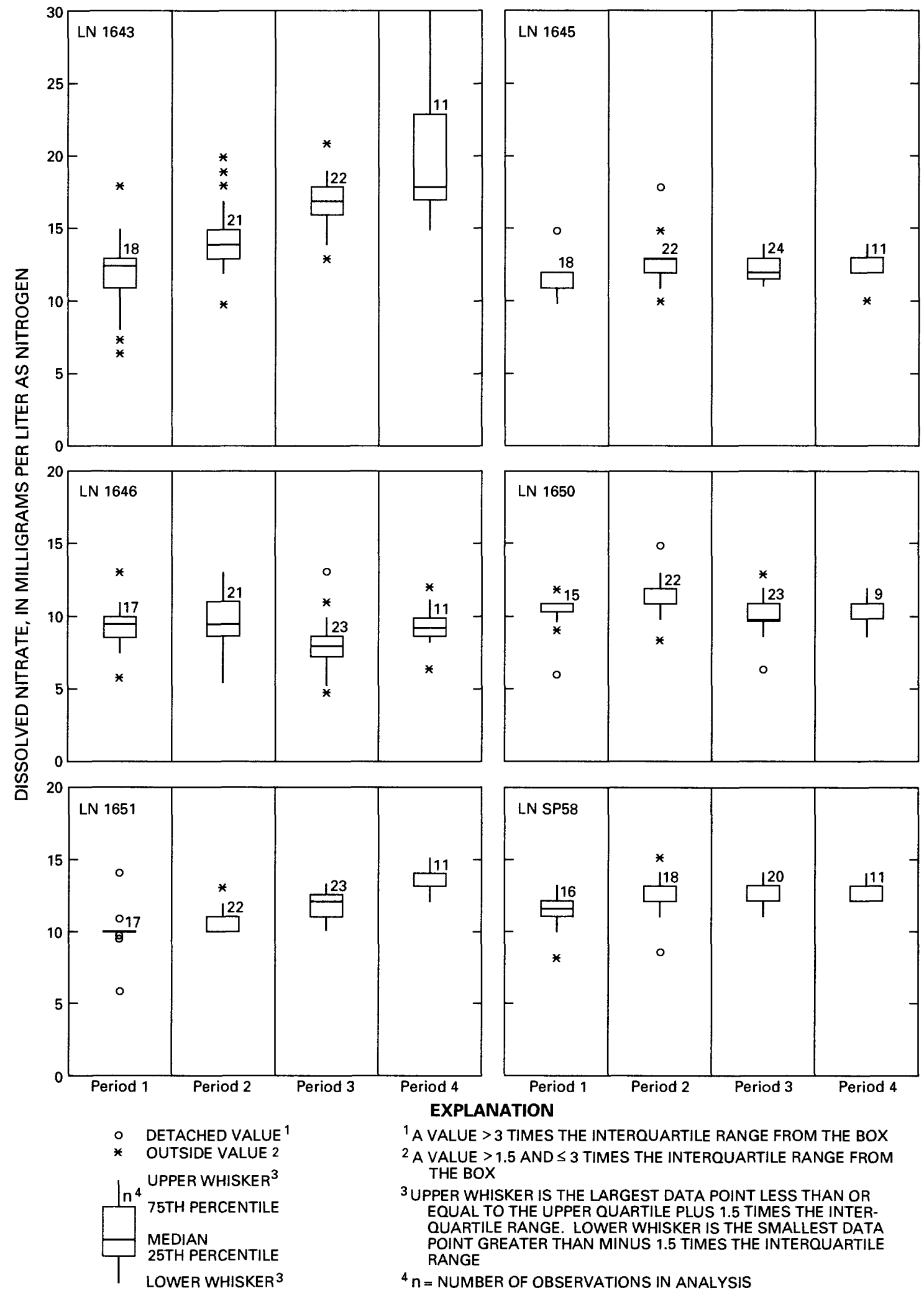

Figure 31.-Concentrations of nitrate at Field-Site 1 in ground-water samples from wells $L N 1643, L N 1645$, LN 1646, LN 1650, LN 1651, and spring LN SP58 for pre-best-management practice Period 1 (January 1983-September 1984) and post-best-management practice Periods 2 (October 1984 September 1986), 3 (October 1986-September 1988), and 4 (October 1988-July 1989). 
Table 24.-Median nitrate concentrations in ground water at Field-Site 1 and results of Mann-Whitney testing between pre- and post-best-management practice periods

[Concentrations are in milligrams per liter as nitrogen; n, number of samples; BMP, best-management practice; $\uparrow$, statistically significant increase at the 95-percent confidence interval; $\downarrow$, statistically significant decrease at the 95 percent-confidence interval; $\leftrightarrow$, no statistically significant changel

\begin{tabular}{|c|c|c|c|c|c|c|c|c|c|c|}
\hline \multirow{2}{*}{$\begin{array}{l}\text { Well or } \\
\text { spring } \\
\text { number }\end{array}$} & \multicolumn{2}{|r|}{ Period $1^{1}$} & \multicolumn{2}{|r|}{ Period $2^{2}$} & \multicolumn{2}{|r|}{ Period 3} & \multicolumn{2}{|r|}{ Period 4} & \multicolumn{2}{|c|}{ Periods 2,3 , and $4^{3}$} \\
\hline & $\mathrm{n}$ & $\begin{array}{c}\text { Median } \\
\text { concentration }\end{array}$ & $\mathrm{n}$ & $\begin{array}{c}\text { Median } \\
\text { concentration }\end{array}$ & $\mathrm{n}$ & $\begin{array}{c}\text { Median } \\
\text { concentration }\end{array}$ & $\mathbf{n}$ & $\begin{array}{c}\text { Median } \\
\text { concentration }\end{array}$ & $\mathbf{n}$ & $\begin{array}{c}\text { Median } \\
\text { concentration }\end{array}$ \\
\hline LN 1643 & 18 & 12.5 & 21 & 14.0 & 22 & 17.0 & 11 & 18.0 & 54 & 17.0 \\
\hline LN 1645 & 18 & 11.0 & 22 & 12.0 & 24 & 12.0 & 11 & 12.0 & 57 & 12.0 \\
\hline LN 1646 & 17 & 9.4 & 21 & 9.4 & 23 & 7.9 & 11 & 9.2 & 55 & 8.8 \\
\hline LN 1650 & 15 & 11.0 & 22 & 11.0 & 23 & 10.0 & 9 & 11.0 & 54 & 11.0 \\
\hline LN 1651 & 17 & 10.0 & 22 & 11.0 & 23 & 12.0 & 11 & 13.0 & 56 & 12.0 \\
\hline \multirow[t]{2}{*}{ LN SP58 } & 16 & 11.5 & 18 & 12.0 & 20 & 13.0 & 11 & 13.0 & 49 & 12.0 \\
\hline & & $\begin{array}{l}\text { Period 1- } \\
\text { Period } 2\end{array}$ & & $\begin{array}{l}\text { Period 1- } \\
\text { Period } 3\end{array}$ & & $\begin{array}{l}\text { Period 1- } \\
\text { Period } 4\end{array}$ & & $\begin{array}{l}\text { Period 1- } \\
\text { Post-BMP }\end{array}$ & & \\
\hline LN 1643 & & $\uparrow$ & & $\uparrow$ & & $\uparrow$ & & $\uparrow$ & & \\
\hline LN 1645 & & $\uparrow$ & & $\uparrow$ & & $\uparrow$ & & $\uparrow$ & & \\
\hline LN 1646 & & $\leftrightarrow$ & & $\downarrow$ & & $\leftrightarrow$ & & $\leftrightarrow$ & & \\
\hline LN 1650 & & $\leftrightarrow$ & & $\leftrightarrow$ & & $\leftrightarrow$ & & $\leftrightarrow$ & & \\
\hline LN 1651 & & $\uparrow$ & & $\uparrow$ & & $\uparrow$ & & $\uparrow$ & & \\
\hline LN SP58 & & $\uparrow$ & & $\uparrow$ & & $\uparrow$ & & $\uparrow$ & & \\
\hline
\end{tabular}

\footnotetext{
${ }^{1}$ Period 1 (January 1983-September 1984) is the pre-best-management practice period.

2 Periods 2 (October 1984-September 1986), 3 (October 1986-September 1988), and 4 (October 1988-July 1989) are the post-bestmanagement practice periods.

${ }^{3}$ Entire post-best-management practice period.
}

Nutrient-application characteristics that changed after nutrient-management recommendations were made were (1) the location of applications varied with crop locations (figs. 5 and 7); (2) the timing of applications was made somewhat less frequently after implementation, especially during the winter (fig. 6); and (3) the consistency of some of the manure, which was applied as bedded pack before BMP implementation and liquid slurry after implementation. Although much of the manure was stored as liquid slurry in a pit constructed to augment the nutrient-management BMP, heifer manure was spread on the fields as available, as was done during the pre-BMP period.

Although pre-BMP surface applications of nutrients were shown to affect nonrecharge ground-water quality at wells LN 1643 and LN 1645 from 1 to 3 months after application, the change in surface nutrient applications was not the predominant influence on changes in ground-water nitrate concentrations through the post-BMP period. Nitrogen applications, except near some of the wells in 1987, generally did not increase from the pre-BMP to post-BMP periods. But, water from three wells and the spring, which is believed to be representative of ground-water quality from the entire site, contained statistically significantly higher nitrate concentrations in the post-BMP period than in the pre-BMP period. In addition, the large increase in nutrient applications for the 1987 crop, made primarily to fields 2,3 , and 4 in the spring of 1987, was not reflected by a large change in ground-water quality at any of the wells near the time of application (fig. 27). 
The increase in ground-water concentrations of nitrate at the three wells and the spring may have resulted from increased nitrate concentrations in infiltrating water as a result of terracing. This hypothesis is supported by evidence from surface-runoff data from the site. During the post-BMP period, nitrate plus nitrite comprised a larger percentage of the load of total nitrogen in runoff relative to the pre-BMP period; 35 percent and less than 10 percent, respectively (table 18). Nitrate concentrations in surface runoff were significantly higher during the post-BMP period than during the pre-BMP period. The median values of the mean storm concentrations of nitrate within the clusters of similar type storms increased twofold to ninefold from Period 1 to Period 3 (table 21). The concentration of nitrate plus nitrite in instantaneous runoff samples during the pre-BMP period ranged from 0.01 to $8.7 \mathrm{mg} / \mathrm{L}$; the median was $0.50 \mathrm{mg} / \mathrm{L}$ for 421 samples. During the post-BMP period, the concentration of nitrate plus nitrite ranged from 0.14 to $45 \mathrm{mg} / \mathrm{L}$; the median was $1.6 \mathrm{mg} / \mathrm{L}$ for 634 samples. The instantaneous surface-runoff samples at the beginning of the event and near or at the end of the event contained the highest concentrations of nitrate during the post-BMP period. Nitrate concentrations in runoff were as high as $29 \mathrm{mg} / \mathrm{L}$ at the end of one storm but varied greatly throughout the study. Higher nitrate concentrations in surface runoff near the end of the storm, when discharges are low, support the hypothesis that leachate contained higher nitrate concentrations during the post-BMP period than during the pre-BMP period when no terracing was in place. Terracing resulted in extended contact time of surface runoff and leachate with the nutrient-rich soils, which could increase dissolution of the available nitrate and increase nitrification rates. Leachate concentrations would be expected to be even greater than runoff concentrations because the leachate samples were in contact with a larger soil profile than the surface-runoff samples. Additionally, many storms that produced runoff during the pre-BMP period produced no runoff during the post-BMP period, which may have resulted in higher soil-moisture levels, which, in turn, may have (1) promoted nitrification, thus increasing the amount of nitrate available to recharge; and (2) led to an increase in infiltration through micropore flow, although the infiltration quantity would not be expected to be substantial enough to be observable by analysis of water-level hydrographs.

Because infiltrating micropore as well as macropore water has greater contact time with nutrient-rich soils than runoff water has, it is reasonable to conclude that a $1.5-\mathrm{mg} / \mathrm{L}$ increase in median concentrations of nitrate plus nitrite in runoff after terracing would be correlated with a 1- to 4-mg/ $\mathrm{L}$ increase in ground-water concentrations of nitrate.

Another indication that changes in surface-runoff concentrations may be indicative of changes in groundwater concentrations is that during the post-BMP period, nitrate concentrations in runoff generally increased at low discharges near the end of the storm except from July through October when the response was highly variable. A cyclical pattern of changes in ground-water concentrations of nitrate observed at well LN 1643 (fig. 27) were similar. Generally, increases in nitrate concentrations occurred throughout the year, except in the late summer and fall, when decreases occurred. The cyclical pattern at well LN 1643 was more pronounced during the post-BMP than the pre-BMP period. During the pre-BMP period, concentrations of nitrate plus nitrite in surface runoff were highly variable during low discharges near the end of the storms, except in May and June when samples generally had higher nitrate concentrations than other samples collected during the storms.

Where there was a substantial change in nitrogen applications in a particular area of the site, changes were also found in ground-water concentrations of nitrate. As a result of cropping changes, the proportion of alfalfa grown upgradient of wells LN 1646 and LN 1650 increased (fig. 5). Generally, nutrient applications to alfalfa were substantially less than applications to corn (table 11). Ground-water concentrations of nitrate in water from wells LN 1646 and LN 1650 were not significantly different from the pre-BMP to post-BMP periods, except from Period 1 to 3 when a significant decrease was detected at LN 1646 (fig. 31, table 24). A combination of cropping changes resulting in substantial reductions in the nutrient applications upgradient of these wells probably caused a reduction in the concentrations of nitrate in ground water. 
In the spring of 1989, nitrate concentrations increased substantially in nonrecharge samples at LN 1643. Smaller increases in concentrations occurred in samples from some of the other wells (fig. 27). By July and again in September, concentrations of nitrate returned to near the levels measured earlier. Although an extremely large application of manure was made to Field 7 in December 1988 (over 2,000 lb/acre), it is not known if this activity directly affected the nitrate concentrations in the well water, but the increase in the concentration of nitrate at well LN 1643 cannot be explained by any of the other available agricultural-activity data.

In summary, the ground-water quality at Field-Site 1 was affected by agricultural practices, although the amount of ground-water recharge was not substantially affected by terracing. A qualitative assessment of data collected from the site shows that the nitrate concentration of recharge water was affected by available nutrients at or near the surface. Changes in runoff characteristics and surface-water-quality data show that the significant increases in ground-water nitrate concentrations from the pre-BMP to the post-BMP period at four of the groundwater-sampling locations was attributable to increased nitrate concentrations in recharge as a result of terracing, which allowed increased contact time of runoff and recharge water with nutrient-rich soils. Also, large decreases in crop-nutrient requirements and applications (because of a crop change from predominantly corn to alfalfa upgradient of two of the wells) masked the effects of terracing on water quality and resulted in either no detectable change or a significant decrease in ground-water concentrations of nitrate from the pre-BMP to the post-BMP period.

\section{SUMMARY AND CONCLUSIONS}

The effects of terracing on surface-runoff and ground-water quantity and quality of an agricultural field site underlain by carbonate rock was investigated from 1983 through 1989 . This study, conducted by the U.S. Geological Survey in cooperation with the Pennsylvania Department of Environmental Protection, was part of the 10-year experimental Rural Clean Water Program sponsored by the U.S. Department of Agriculture. Field-Site 1, located in the Conestoga River Headwaters Basin in Lancaster County, Pa., is 23.1 acres of conventionally tilled cropland, planted primarily in corn and alfalfa. Manure from the daily operation supplied most of the nutrients for crops fertilization. The silt-loam soils on an average slope of 6 percent are deep and well drained. Normal precipitation at Field-Site 1 was 42 in. per year. Runoff during the 7 -year study period averaged 11 percent of precipitation, and recharge averaged 37 percent of precipitation.

Terracing did not cause an overall change in the relation of runoff quantity to precipitation. However, terracing changed runoff characteristics and increased the runoff threshold. Before terracing, the runoff hydrograph had numerous peaks of different sizes caused by varying rainfall intensities and runoff reaching the gage from different parts of the field. After terracing, water retention in the terraces and steady drainage through the pipe outlets resulted in a stepwise decline in stage as the terraces drained. After terracing, small storms, generally less than 0.4 in., did not produce runoff.

Terracing was effective in reducing suspended-sediment yields from the site but ineffective in reducing nitrogen or phosphorus yields in runoff from the site. Suspended-sediment yields as a function of runoff were significantly reduced after a period of terrace stabilization and establishment of crop changes planned as part of the terracing BMP. Reductions in the suspended-sediment yields were larger during storms with larger runoff amounts. Yields of total phosphorus as a function of runoff did not change significantly after terracing. Limited data suggest that fine-sediment particles, with which most of the phosphorus is associated, continued to be transported from the site. Although nitrate plus nitrite yields as a function of runoff increased significantly after terracing, total nitrogen loads did not change significantly. Loads of total nitrate plus nitrite comprised 35 percent of the total nitrogen load after terracing, compared to 10 percent of the load before terracing. 
Terracing of the site did not cause statistically significant changes in the quantity of recharge to the aquifer at the site. However, the amount of recharge to ground water at the site decreased from the pre-BMP to the post-BMP period because of changes in precipitation quantity and timing and other climatic factors. No changes in annual mean water levels were detected in water-level data from the site during the study period.

Nitrate concentrations in ground-water samples commonly exceeded the USEPA maximum contaminant level of $10 \mathrm{mg} / \mathrm{L}$ nitrate as nitrogen. Concentrations of dissolved nitrate in ground-water samples accounted for greater than 90 percent of the total nitrogen in ground water, and concentrations of nitrate were identified as being a good indicator of the effects of BMP implementation on ground-water concentrations of nitrogen.

Concentrations of nitrate in ground water increased significantly at four of the wells after terracing. Changes in runoff characteristics and surface-water-quality data indicate that the increases were attributable to increased nitrate concentrations in recharge as a result of terracing, which increased contact time of runoff and recharge water with nutrient-rich soils. Large decreases in nitrogen applications because of a crop change from predominantly corn to alfalfa upgradient of two of the wells resulted in either no significant change or a significant decrease in nitrate concentrations of ground water from the pre-BMP to the post-BMP period.

\section{REFERENCES CITED}

Buchanan, J.W., Loper, W.C., Schaffstall, W.P., and Hainly, R.A., 1984, Water resources data, Pennsylvania, water year 1983, volume 2-Susquehanna and Potomac River Basins: U.S. Geological Survey Water-Data Report PA-83-2, 283 p.

Chichester, D.C., 1988, Evaluation of agricultural Best-Management Practices in the Conestoga River headwaters, Pennsylvania-Methods of data collection and analysis, and description of study areas: U.S. Geological Survey Open-File Report 88-96, 32 p.

Conover, W.J., 1980, Practical nonparametric statistics (2d ed.): New York, John Wiley and Sons, 493 p.

Gerhart, J.M., 1986, Ground-water recharge and its effects on nitrate concentration beneath a manured field site in Pennsylvania: Ground Water, v. 24, no. 4, p. 483-489.

Helsel, D.R., and Hirsch, R.M., 1992, Statistical methods in water resources: Amsterdam, Elsevier Publishers, $522 \mathrm{p}$.

Iman, R.L., and Conover, W.J., 1983, A modern approach to statistics: New York, John Wiley and Sons, 497 p.

Lancaster County Conservation District, 1982, Assessment of non-point sources of pollution from agriculture in the Conestoga River Watershed: Lancaster County Conservation District, 6 p.

Lietman, P.L., Gerhart, J.M., and Wetzel, K.L., 1989, Comparison of methods for sampling dissolved nitrogen in a fractured carbonate-rock aquifer: Ground Water Monitoring Review, v. 9, no. 1, p. 197-202.

Lietman, P.L., and others, 1996, Evaluation of agricultural best-management practices in the Conestoga River Headwaters, Pennsylvania-Characterization of surface-runoff and ground-water quantity and quality in a small carbonate basin near Churchtown, Pennsylvania, prior to terracing and implementation of nutrient management: U.S. Geological Survey Water-Resources Investigations Report 93-4119, p. 103.

Loper, W.C., Behrendt, T.E., and Schaffstall, W.P., 1985, Water resources data, Pennsylvania, water year 1984, volume 2-Susquehanna and Potomac River Basins: U.S. Geological Survey Water-Data Report PA-84-2, $327 \mathrm{p}$. 
1987-90, Water resources data, Pennsylvania, water years 1986-89, volume 2-Susquehanna and Potomac River Basins: U.S. Geological Survey Water-Data Report PA-86-2 to PA-89-2 (published annually).

Loper, W.C., Behrendt, T.E., Schaffstall, W.P., and Hainly, R.A., 1986, Water resources data, Pennsylvania, water year 1985, volume 2-Susquehanna and Potomac River Basins: U.S. Geological Survey Water-Data Report PA-85-2, $361 \mathrm{p}$.

National Oceanic and Atmospheric Administration, 1983-89, Climatological data, annual summary: v. 88-94, no. $13,26 \mathrm{p}$.

P-STAT, Inc., 1986, P-STAT-User's manual: Boston, Duxbury Press, 852 p.

Pennsylvania Department of Environmental Resources, 1983, An assessment of agricultural non-point source pollution in selected high priority watersheds in Pennsylvania: Bureau of Soil and Water, $48 \mathrm{p}$.

Pennsylvania State University, 1987, The Penn State Agronomy Guide: Pennsylvania State University, 64 p.

SAS Institute, Inc., 1979, SAS users guide (1979 ed.): Cary, N.C., SAS Institute, Inc., 494 p. 1982a, SAS users guide—Basics (1982 ed.): Cary, N.C., SAS Institute, Inc., 924 p. 1982b, SAS users guide—Statistics (1982 ed.): Cary, N.C., SAS Institute, Inc., 584 p.

Searcy, J.K., and Hardison, C.H., 1960, Double-mass curves: U.S. Geological Survey Water-Supply Paper 1541-B, $66 \mathrm{p}$.

Stevenson, F.J., ed., 1982, Nitrogen in agricultural soils: New York, Academic Press, 940 p.

Thornthwaite, C.W., 1948, An approach toward a rational classification of climate: Geographic Review, 38, p. 55-94.

U.S. Department of Agriculture, 1982, Conestoga Headwaters Rural Clean Water Program Comprehensive Monitoring Plan: $45 \mathrm{p}$.

1985, Soil survey of Lancaster County, Pennsylvania: 152 p.

U.S. Environmental Protection Agency, 1992, Drinking-water regulations and health advisories: April 1992, $13 \mathrm{p}$.

White, R.E., 1985, The influence of macropores on the transport of dissolved and suspended matter through the soil-Advances in soil science, volume 3: New York, Springer-Verlag, p. 95-119.

Wilkinson, Leland, 1988, SYSTAT-The system for statistics: Evanston, Ill., SYSTAT, Inc., 822 p. 